$$
\begin{gathered}
\text { Carmen María } \\
\text { Ló pez Rico } \\
\text { Prologuista } \\
\text { Guillermo Ló pez García }
\end{gathered}
$$

\title{
El principio del fin de las televisiones públicas La deriva de Canal 9
}

Cuadernos Artesanos de Comunicación / 105

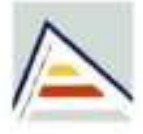

Universitat d'Alacant Universidad de Alicante
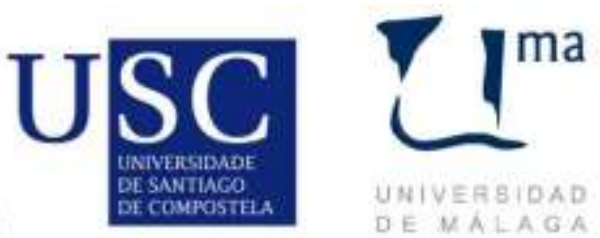

UNIVERSIDAD

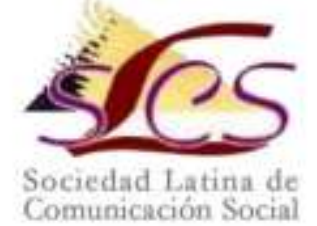




\section{Cuadernos Artesanos de Comunicación}

Coordinador editorial: José Manuel de Pablos - jpablos@ull.edu.es

Comité Científico

Presidencia: José Luis Piñuel Raigada (UCM)

Secretaría: Concha Mateos (URJC)

- Javier Marzal (Universidad Jaume I, UJI)

- José Antonio Meyer (Benemérita Universidad Autónoma de Puebla, BUAP)

- Ramón Reig (Universidad de Sevilla, US)

- Miquel Rodrigo Alsina (Universidad Pompeu Fabra, UPF)

- Xosé Soengas (Universidad de Santiago de Compostela, USC)

- José Luis Terrón (Universidad Autónoma de Barcelona, UAB)

- José Miguel Túñez (Universidad de Santiago, USC)

- Victoria Tur (Universidad de Alicante, UA)

- Miguel Vicente (Universidad de Valladolid, UVA)

- Ramón Zallo (Universidad del País Vasco, UPV-EHU)

- Núria Almiron (Universidad Pompeu Fabra, UPF)

- Francisco Campos Freire (Universidad de Santiago de Compostela, USC)

- José Cisneros (Benemérita Universidad Autónoma de Puebla, BUAP)

- Bernardo Díaz Nosty (Universidad de Málaga, UMA)

- Carlos Elías (Universidad Carlos III de Madrid, UC3M)

- Paulina B. Emanuelli (Universidad Nacional de Córdoba, UNC)

- José Luis González Esteban (Universitas Miguel Hernández de Elche, UMH)

- Marisa Humanes (Universidad Rey Juan Carlos, URJC)

- Juan José Igartua (Universidad de Salamanca, USAL)

-Octavio Islas (Universidad de los Hemisferios, Ecuador)

- Xosé López (Universalidad de Santiago de Compostela, USC)

- Maricela López-Ornelas (Universidad Autónoma de Baja California, AUBC)

* Queda expresamente autorizada la reproducción total o parcial de los textos publicados en este libro, en cualquier formato o soporte imaginables, salvo por explícita voluntad en contra del autor o autora o en caso de ediciones con ánimo de lucro. Las publicaciones donde se incluyan textos de esta publicación serán ediciones no comerciales y han de estar igualmente acogidas a Creative Commons. Harán constar esta licencia y el carácter no venal de la publicación.

\section{$(1) \Theta \Theta$} incluidas, si no se indica lo contrario, se encuentran bajo una Licencia Creative Commons Atribución-No Comercial-Sin Derivadas 3.0 Unported. Puede ver una copia de esta licencia en http://creativecommons.org/licenses/by-nc-nd/3.0/ Esto significa que Ud. es libre de reproducir y distribuir esta obra, siempre que cite la autoría, que no se use con fines comerciales o lucrativos y que no haga ninguna obra derivada. Si quiere hacer alguna de las cosas que aparecen como no permitidas, contacte con los coordinadores del libro o con el autor del capítulo correspondiente. ${ }^{*}$ La responsabilidad de cada texto es de su autor o autora.

* La responsabilidad de cada texto es de su autor o autora. 


\title{
Carmen María López Rico
}

\author{
Prologuista \\ Guillermo López García
}

\section{El principio del fin de las televisiones públicas La deriva de Canal 9}

Cuadernos Artesanos de Comunicación / 105

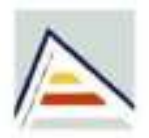

Universitat d'Alacant Universidad de Alicante
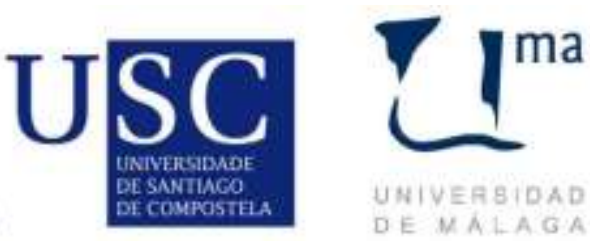

UNIVERBIDAD 
$105^{\circ}$ - El principio del fin de las televisiones públicas. La deriva de Canal 9

Carmen María López Rico (iD 7

Precio social: $6,55 € \mid$ Precio en librería. 8,50€

Editores: Javier Herrero y Milena Trenta

Diseño: F. Drago

Ilustración de portada: Fragmento del cuadro Mujer con bernegal, de Pedro de Guezala (1958).

Imprime y distribuye: F. Drago. Andocopias S. L.

c/ La Hornera, 41. La Laguna. Tenerife.

Teléfono: 922250554 | fotocopiasdrago@,telefonica.net

Edita: Sociedad Latina de Comunicación Social - edición no venal - La Laguna (Tenerife), 2016 - Creative Commons http://www.revistalatinacs.org/14SLCS/portada2014.html

Descargar en pdf:

http://www.cuadernosartesanos.org/\#105

Protocolo de envío de manuscritos

http://www.cuadernosartesanos.org/protocolo.html

ISBN - 13: 978-84-16458-47-9

DL: TF-301-2016

DOI: $\underline{10.4185 / \mathrm{cac} 105}$ 


\section{Agradecimientos}

Publicación financiada por el grupo de I+D "Los flujos de comunicación en los procesos de movilización política: medios, blogs y líderes de opinión" (referencia CSO2013-43960-R). Proyecto financiado por el Ministerio de Economía y Competitividad (2014-2016), dirigido por Guillermo López García, profesor titular de Periodismo (Universidad de Valencia).

Al Instituto Juan Gil Albert de Alicante por su ayuda a la investigación para la tesis doctoral, cuyos resultados forman parte de este libro.

\section{El principio del fin de las televisiones públicas. La deriva de Canal 9}

(Publicado en abril de 2016)

\section{Abstract}

Esta publicación pretende recopilar la historia de Radio Televisión Valenciana, haciendo un recorrido desde sus inicios hasta su cierre, incluyendo las medidas que se están efectuando para su nueva puesta en marcha.

Igualmente se muestran resultados sobre el tratamiento informativo que se realizó durante las elecciones generales y valencianas de 2011, las últimas que cubrió RTVV. Queda patente la calidad del modelo gestionado por Fran Llorente en La 1 (TVE), en contraposición con la mala praxis de Canal 9 (RTVV). Una televisión en declive, que se aproximaba hacía su clausura y que actualmente está en proceso de reapertura, de la mano del nuevo Gobierno de la Generalitat Valenciana.

Keywords: Pluralismo; Televisión pública; Partidismo; Comunicación Política, Canal 9, RTVE

\section{Forma de citar este libro}

Carmen M. López-Rico (2016): El principio del fin de las televisiones públicas. La deriva de Canal 9. Cuadernos Artesanos de Comunicación, 105. La Laguna (Tenerife): Latina. 


\section{Índice}

Prólogo. RTVV: Lo que pudo ser y no fue

Dr. Guillermo López García, profesor titular de Periodismo en la Universidad de Valencia ..........................................................

Capítulo 1: Introducción. ¿Quién controla los medios? .............. 11

- Agentes económicos

- El poder político

- Las empresas informativas, la competencia y la concentración de medios

Capítulo 2: Control de la información política en las

televisiones públicas

- Las campañas electorales estadounidenses como máximo exponente

- Tratamiento informativo en La 1 y Canal 9 durante las elecciones de 2011

Capítulo 3: Deriva de las televisiones públicas en España........... 65

- Del modelo BBC de Fran Lorente en RTVE a los ERES, el telepartidismo y las privatizaciones

- Diferencias de financiación

- Privatización de las televisiones públicas

- Televisión pública partidista

Capítulo 4: Cómo se cierra una televisión pública: El caso de Canal 9

Capítulo 5: Una segunda oportunidad para RTVV

\section{Bibliografía}




\author{
Prólogo
}

\title{
RTVV: Lo que pudo ser y no fue
}

\author{
Guillermo López García ${ }^{1}$
}

\begin{abstract}
T OS últimos años no han sido fáciles para los valencianos. A la 1 crisis económica, que padecemos con particular virulencia por el peso del sector inmobiliario, los enormes desequilibrios en la financiación autonómica y la irresponsabilidad en la gestión de las cuentas públicas por parte de nuestros representantes políticos, se ha unido, como consecuencia directa de estos problemas, una crisis de legitimidad política que ha devenido en social, y que tuvo como consecuencia inmediata un vuelco electoral en los comicios locales y autonómicos de mayo de 2015 sin parangón en el resto de España: el Partido Popular, que gobernaba en casi todas las instituciones con una cómoda mayoría absoluta, se desplomó por debajo del 30\% de los votos y perdió la Generalitat Valenciana, la Diputación de

\footnotetext{
${ }^{1}$ Licenciado en Comunicación Audiovisual y Doctor en Comunicación. Actualmente es profesor titular en el área de Periodismo de la Universidad de Valencia, e investigador principal del proyecto I $+\mathrm{D}$ del Ministerio de Economía Mediaflows. Sus principales líneas de investigación abarcan la Opinión Pública, Comunicación Política y Comunicación en Internet, sobre los que ha publicado un gran número de comunicaciones, artículos y libros al respecto. http://www.uv.es/=guilopez/curriculum/index.htm
} 
Valencia y el gobierno de las ciudades más importantes, entre ellas las tres capitales de provincia.

El legado del gobierno del Partido Popular puede leerse como un 'reverso tenebroso' de los años de bonanza, con su obsesión por el ladrillo, la imagen y los grandes eventos. En efecto, la imagen de los valencianos, en el exterior, pero también entre nosotros, nunca había adquirido tintes tan negativos: la Comunidad Valenciana es vista por muchos como la quintaesencia de la corrupción, el despilfarro y la ineficacia en la gestión pública. Y, desde hace ya algún tiempo, en este proceso ha brillado con luz propia el sistema autonómico de radio y de televisión públicas engarzado en torno al ente de Radio Televisió Valenciana (RTVV), finalmente extinguido por la fuerza de los decretos - ley de urgencia emanados desde la Generalitat Valenciana.

El final de RTVV, por desgracia, estuvo a la altura de su devenir previo. Se trataba de unos medios públicos deslegitimados por su escasa audiencia y su acendrado partidismo (dos factores que a menudo vienen ligados), así como por el desbarajuste monumental en las cuentas, con una deuda superior a los 1.200 millones de euros.

Su cierre, justificado (por decir algo) desde el Consell como una medida inevitable de ahorro (pero, en realidad, vinculado más bien con el afán del presidente de la Generalitat, Alberto Fabra, por aparentar firmeza ante sus avalistas en el gobierno central y en los medios de comunicación madrileños, notoriamente el diario El Mundo), resultó trágico, cómico por surrealista y, en fin, terrible. Por las circunstancias en las que se dio y, sobre todo, por las consecuencias que comporta: los valencianos somos una de las pocas comunidades autónomas españolas (junto con Navarra, Cantabria y La Rioja) que no cuentan con medios públicos de dimensión regional.

Si pensamos en la dimensión de la Comunidad Valenciana, con cinco millones de habitantes, y en la incidencia de la lengua propia (el valenciano) y la importancia que para su aprendizaje y preservación tiene contar con un vehículo de difusión potente en los medios de comunicación, podemos hacernos una idea de la dimensión que adquiere la desaparición de RTVV. 
Este libro habla del cierre de RTVV, pero sobre todo habla de algunos de los motivos que condujeron al mismo, y también propone modelos de funcionamiento de los medios audiovisuales públicos que, ahora que se está debatiendo el modelo de la futura RTVV, que se espera comience su andadura en pocos meses, resultan particularmente oportunos. Tuve el placer de formar parte, hace dos años, del tribunal que evaluó la tesis doctoral de la autora, que es el germen de este libro. En la tesis, como en el libro, Carmen $\mathrm{M}^{\mathrm{a}}$ López nos explica perfectamente no sólo qué ocurrió en RTVV, sino por qué ocurrió.

Es una lectura agridulce, porque nos habla de la historia de un fracaso. Y porque lo hace, además, sin medias tintas, aportándonos datos apabullantes que avalan las condiciones de manipulación informativa sistemáticamente presentes en RTVV y sus insuficiencias como servicio público. Una lectura que va mucho más allá de la divulgación y el análisis argumentativo (sin duda necesarios, y que, de hecho, también están presentes), porque cimenta sus conclusiones en una investigación tan sólida y ambiciosa como fecunda en sus resultados. 



\section{Introducción: ¿Quién controla los medios?}

E STA cuestión está en constante revisión por la sociedad, los mercados, los políticos y todos aquellos sectores que quieren controlar los medios de comunicación, pues en definitiva tener poder sobre los mismos, significa controlar en gran medida a la opinión pública.

Como afirma Noam Chomsky, en una democracia hay una clase especializada que decide y guía a la sociedad basándose, en principio, en los intereses comunes del resto de la sociedad. Su función no es participativa, sino que los ciudadanos se convierten en espectadores que delegan en miembros de esa clase especializada. Ahora bien, como es una democracia y no una dictadura, de vez en cuando a los ciudadanos:

"se les permite decir queremos que seas nuestro líder, o, mejor, queremos que tú seas nuestro líder (...). Pero una vez se han liberado de su carga y traspasado está a algún miembro de la clase especializada, se espera de ellos que se apoltronen y se conviertan en espectadores de la acción, no en participantes. Esto es lo que ocurre en una democracia que funciona como Dios manda." (Chomsky, 1996:12)

Según Andreu Casero la importancia de la información política reside fundamentalmente en su función de definir la realidad a través de la realidad simbólica. Esto se debe a que es el recurso cognitivo y simbólico principal para el conocimiento social. Además, ordena y prioriza la agenda social otorgando más o menos relevancia a los 
temas que la sociedad debe prestar atención, mientras está formando la opinión pública (Casero, 2009).

Desde la Escuela de Frankfurt (1930-1970) ya "denunciaban que los medios de comunicación de masas estaban al servicio de las clases dominantes y manipulaban ideológicamente a los individuos, generándoles una falsa conciencia de que viven en una sociedad justa y democrática" (Cisneros, 2002: 12).

Ahora veamos quiénes son los actores que influyen en mayor medida sobre los medios de comunicación y cuáles son sus intereses.

\section{Agentes económicos}

Es cierto que los medios de comunicación son empresas y como tales, buscan beneficios, por ello el principal condicionante que amenaza la independencia de un medio es el Mercado. Si la titularidad del medio es privada o pública es indiferente, puesto que la principal diferencia es la procedencia de los recursos, pues de igual modo los medios públicos deben ser sostenibles para poder continuar prestando el servicio a los ciudadanos.

Por este motivo, las empresas informativas se centran en un enfoque de las noticias más espectacular y lúdico dejando cada vez más al margen lo que denominamos 'hard news', es decir: política, economía y cultura a favor de un info-entretenimiento que proporciona mejores resultados mercantilistas gracias a la audiencia. Sin embargo, "el potencial político, creativo e industrial de la televisión estaría en comunicar para ciudadanos y no para consumidores" (Rincón, 2006).

Los medios introducen cada vez más publicidad, en todo tipo de programas y en cualquier momento. En algunos casos, otorgándole más importancia a los anunciantes que a la propia información, porque según Mario Caciagli, "los medios televisivos están conectados con el dinero y pueden implicar una manipulación sin remedio" (Molins, et. al. 2006: 19).

Las cifras generales en Europa, con la mayor crisis económica registrada desde el Crack del 29 como contexto, revelan que la recesión ha afectado más a la televisión privada que a los canales 
públicos, debido a sus diferentes fuentes de financiación. Las primeras se sostienen fundamentalmente de la financiación pública, a través de tasas o de ayudas estatales, mientras que la privada depende de la publicidad y de su audiencia como posibles consumidores de los anunciantes (Campos-Freire, 2013).

En este sentido, la BBC británica tiene un modelo de financiación envidiable, gracias al cual consiguen mantener un presupuesto asequible y obtener ingresos tanto de los ciudadanos, como de la venta de sus producciones.

Sin embargo, también tienen sus propios quebraderos de cabeza. En el plan estratégico 2011-2016 se vio obligada a reducir en un $25 \%$ el presupuesto, debido a la congelación del canon (169.8 euros al año por vivienda) y a cancelar la inversión en la Web. En 2016 ha recortado el presupuesto de la televisión en 12 millones de libras, debido a la pérdida de 150 millones de libras que se estima en la recaudación del canon para 2016/2017. Esta caída de ingresos está causada por el aumento de usuarios en BBC iPlayer y de otras plataformas como Netflix o Lovefilm en detrimento de la televisión off-line ${ }^{2}$.

Por otro lado, desde los escándalos Saville y McAlpine en 2012, su credibilidad se ha visto afectada indirectamente (Ibíd., 2013), pudiendo influir en parte en el consumo televisivo. Ahora bien, sigue siendo un modelo en el que poder mirarse otras televisiones públicas, que todavía no alcanzan el grado de madurez de la corporación británica.

\section{El poder político}

Los políticos son el segundo agente que intenta interferir en los medios de comunicación con mayor intensidad. En primer lugar, controlan los medios desde el momento en el que el Ejecutivo es quien distribuye las licencias a las empresas mediáticas. Pueden asegurarse qué empresas son más cercanas a su política y por extensión el contenido que éstas ofrecerán también.

\footnotetext{
${ }^{2}$ Noticia consultada el 25-02-2016 en http://www.audiovisual451.com/bbcreduce-el-presupuesto-de-television-en-12-millones-de-libras-pero-no-toca-lasseries-dramaticas/
} 
Además, deciden si prefieren "el impulso del sector público o del sector privado y las propuestas legislativas que regulen la actividad, los controles y las exigencias" (Cebrián, 2004: 37). De hecho, esta práctica ha llevado a generar grandes conflictos con la implantación del TDT en lugares como Elche (Alicante), ya que su televisión local Tele $\mathrm{Elx}^{3}$ quedó fuera del reparto de licencias, en pos de la empresa Mediamed. Compañía que fue creada con el fin de presentarse al concurso, siendo uno de los implicados en la trama Gürtel su accionista mayoritario (Xambó, 2010:13). Mediamed, fue el mayor adjudicatario de licencias en 2005, obteniendo trece de las cuarenta y dos licencias que salieron a concurso en la Comunidad Valenciana.

En definitiva, el poder político busca según Casero (2009):

- Acceso al espacio informativo. Buscando una visibilidad sistémica

- Dominar los diferentes modos de presentar la información. Eligiendo el mejor horario y/o espacio en que aparecen, cambiar la estrategia ofensiva por defensiva si la información sobre el partido o el líder es negativa, e intentan controlar la información negativa para que no aparezca ni tenga relevancia en los medios.

\footnotetext{
${ }^{3}$ El Tribunal Supremo anula la resolución de 30 de enero de 2006 firmada por el entonces Conseller de Relaciones Institucionales y Comunicación, Esteban González Pons. Atiende así el recurso presentado por la propietaria de Tele Elx, una de las 46 firmas que no logró ninguna de las frecuencias que se adjudicaron. Esta sentencia considera ilegal el reparto de emisoras que el Consell de Francisco Camps abordó a través de la empresa Doxa Consulting. El 18 de julio de 2008 el Tribunal Superior de Justicia de la Comunidad Valenciana dio la razón a la Generalitat y desatendió el recurso presentado por Tele Elx. En aquel polémico reparto la empresa Mediamed Comunicación Digital, presidida por el constructor José Luis Ulibarri, se llevó 13 concesiones. Ulibarri, está imputado en el caso Gürtel por el presunto pago de 3 millones de euros en comisiones por obras para su empresa UFC en ayuntamientos controlados por la trama de Correa. Noticia consultada el 15-09-2012 en http://www.levanteemv.com/comunitatvalenciana/2012/09/14/supremoanul a-reparto-44-tdt-consellprivatizo-seleccion-ofertas/935878.html

Finalmente, tras interponer la correspondiente denuncia, el Tribunal Supremo ha dado la razón a la televisión local ilicitana y ha conseguido mantener su licencia de emisión.
} 
- Dominar el tratamiento y enfoque informativo. Protegiendo su mensaje para que llegue íntegro a su audiencia sin que sea procesado por los medios. Por ejemplo, las cada vez más frecuentes señales realizadas que los partidos ofrecen a los medios durante los mítines. Mientras lo venden como una facilidad para los profesionales, en realidad, están mermando su autonomía.

Para ejercer dicho control se utilizan cuatro estrategias fundamentalmente:

- Adoptar la lógica de la televisión en la creación del material que ofrecen. Si sigues las pautas de producción televisivas el mensaje no tendrá que ser adaptado y por tanto hay más posibilidades de que el medio lo utilice tal y como se lo entregas.

- Tutelar la información en campaña electoral. En algunos casos, como ocurría en Canal 9, los partidos y la cadena pactan qué actos de campaña quieren que sean cubiertos por los medios para ocupar el tiempo que la Ley Electoral pone a su disposición, según su representación parlamentaria en las elecciones anteriores.

- Alianzas con las empresas informativas. En ocasiones los propios partidos políticos tienen alianzas con grupos de comunicación que ideológicamente se posicionan a su favor, en algunos casos porque gente ligada a un partido pasa a ser parte del grupo. Ejemplo de ello es la contratación de Miguel A. Rodríguez, exsecretario de Estado de Comunicación con Aznar, por parte de la productora Secuoya ${ }^{4}$.

- 'Going public'. Es decir, emitir su mensaje directamente para el espectador sin tener que pasar por la producción periodística. Por ejemplo, los discursos en directo que hacen los presidentes de EE.UU. ante toda la Nación, o programas como los que realizaba Hugo Chávez en Venezuela, donde los ciudadanos le realizaban preguntas al presidente, etc. (Ibid., 2009)

\footnotetext{
${ }^{4}$ Véase epígrafe "Diferencias de financiación" en capítulo 3
} 
Huelga decir que en estos tiempos de descrédito para la política los esfuerzos de los partidos se intensifican, dando lugar a hechos tan inaceptables como el intento de control que sufrieron los profesionales de RTVE en 2011, cuando el Consejo de Administración del ente quería tener acceso a la herramienta de creación de noticias. Y qué decir de las 'estrategias' de los gabinetes de prensa de los partidos políticos. Estamos viendo a nuestros políticos negarse a responder preguntas o directamente no comparecer ante los periodistas, como la bochornosa actitud del presidente del Gobierno, Mariano Rajoy, que realizó sus declaraciones a través de una pantalla o su ya famosa respuesta a la pregunta sobre el encarcelamiento de Luis Bárcenas: "A la segunda ya tal".

A esto debemos sumar la calidad del lenguaje que usan nuestros políticos, abusando de los eufemismos o la innecesaria y errónea retórica de las palabras, que se convierte en un vehículo más para la manipulación y el control de la situación. Prueba de ello es la utilización de frases hechas como: guerra preventiva, daños colaterales, sin papeles, plan de reestructuración, crecimiento cero, cementerio nuclear, etc. y las metáforas más elaboradas de los últimos años como los "brotes verdes" del expresidente J. L. Rodríguez Zapatero o el despido "en diferido" de Dolores de Cospedal. En cuanto a las palabras grandilocuentes, algunos de los ejemplos que escuchamos en los medios son: tensionamiento en vez de tensión, intencionalidad por intención, problemática en vez de problema, etc.

Ya lo advertía el filólogo y miembro de la Real Academia de la Lengua Española (RAE), Fernando Lázaro Carreter:

"Los gobernantes deberían ser los primeros en cumplir con las leyes lingüísticas, y no lo hacen, (...) Deberían saber que el idioma es garantía de convivencia y de comprensión mutua. Es un instrumento esencial de la democracia." ${ }^{5}$

Las ansias de control son tales, que en la Comunidad Valenciana pudimos asistir al cierre de los repetidores que el grupo ciudadano

\footnotetext{
${ }^{5}$ Entrevista consultada el 26-09-2013 en http://elpais.com/diario/2003/01/21/cultura/1043103601 850215.html
} 
'Acción Cultural' decidió instalar en 1986 para ver TV3, ya que por aquel entonces no había televisión autonómica en la Comunidad Valenciana.

Con la llegada de ésta en 1989 los repetidores continuaron conviviendo con RTVV, hasta que en 2006 la Generalitat modificó la Ley audiovisual valenciana obligando con multas y demandas a que la plataforma ciudadana fuese apagando los repetidores. Finalmente, el 17 de febrero de 2011 se desconectó el último de ellos, dejando a la Comunidad Valenciana sin la señal de TV3 por motivos políticos, pues para algunos sectores valencianos, la televisión catalana se escapaba al control de la Generalitat Valenciana.

Estos ejemplos muestran el temor de los responsables públicos hacía el Cuarto Poder y como, cuando no son capaces de controlar la información, se atrincheran en la práctica del silencio. No obstante, sus intentos por el control no cesan, ni cesarán, porque es un pastel que todos quieren repartirse.

Desde el Consejo de Informativos de TVE, afirman que estas prácticas "denotan la baja calidad democrática de nuestros políticos". Por su parte, la ex editora del Telediario 1, Pepa Rodríguez realiza una autocrítica de los periodistas porque:

“A veces se selecciona el total más efectista en vez de el que tiene mayor importancia informativa, creo que es una cosa en la que hemos caído todos los medios de comunicación y forma parte de la relación entre periodistas y políticos, se retroalimenta. Entonces los políticos ya saben que si colocan el mensaje que quieren colocar en medio de una declaración absolutamente llamativa pues tienen más posibilidades de salir que si simplemente dan argumentos" (López, 2012)

Por ello, Rodríguez cree que desde los medios se está ayudando a promover la espectacularización de la política en detrimento de la información y esto se debe, en parte al entorno social, para el cual se elabora y difunde la información. Por eso "la televisión se entrega más a lo interesante que a lo realmente importante". Sin embargo, también depende de cómo ese hecho afecta a la sociedad, ya que "existe una agenda social de preocupaciones, de sensibilidades, de 
intereses que los medios tratan de cubrir." (Op. Cit. 2004:40) y que de igual forma influye en el tratamiento de la información.

\section{Las empresas informativas, la competencia y la concentración de medios}

Por último, el tercer condicionante que amenaza a los medios son las propias empresas informativas en sí mismas. Como ya hemos mencionado y puesto que son empresas, en ocasiones actúan de una forma meramente mercantil, sin atender a cuestiones deontológicas y profesionales, atentando contra su propia independencia y calidad informativa. En este caso las sinergias, los ERE, los recortes y la multidisciplinariedad de los profesionales, entre otros aspectos, ejercen una gran influencia en el contenido final de las noticias.

Los propios medios de comunicación atentan contra su independencia, en el momento en que basan sus contenidos en lo que la competencia cree noticioso. Actualmente los medios se vigilan constantemente, incluso entre distintos formatos, la prensa observa lo que se emite en las televisiones o se publica en Internet y viceversa. Todos se siguen para tener las mismas noticias que los demás. En definitiva, esta práctica deteriora la calidad de los contenidos informativos porque no son seleccionados por su interés noticioso sino porque deben estar para imitar a la competencia, lo que significa una homogeneización de la información que consumimos.

El Consejo de Informativos de RTVE insta a los periodistas a que "hagamos nuestro trabajo sin esa servidumbre del si yo no lo cubro, lo pondrá otro medio y cuando nos plantemos de verdad, seguramente los políticos tendrán que elegir" entre la atención de los medios y sus condiciones.

Ante este contexto, "los profesionales reaccionan y tratan de crear Comités de Redacción para alcanzar una mayor autonomía respecto al poder de la Dirección, pero se les niega bajo argumentaciones de diverso tipo", afirma Cebrián (2004), quien destaca que en los debates sobre autorregulación:

"Lo que subyace con frecuencia en esos debates no es un enfrentamiento de profesionales con la Dirección, sino entre profesionales contaminados o dominados por sus 
correspondientes grupos sindicales y políticos que quieren introducir sus planteamientos y controlar y dominar la información con el enfoque que les interesa a ellos o a su propio grupo en detrimento de lo que a unos y a otros les debería preocupar: el ciudadano bien informado." (Op. Cit., 2004:41-45)

De este modo, todos estos sectores toman partido en el intento de control mediático. El ex director de Programación y Gestión de Contenidos de TVE, Xavier Obach afirmaba en este sentido que, aunque se intente apostar por:

"la independencia y la pluralidad, esto no significa que no recibamos presiones de todo el mundo, a todas horas, todos los días del año; es decir todo el mundo llama para presionar, todos, desde la Coca-Cola, a las farmacéuticas, la patronal, los sindicatos, los indignados, las ONG, los partidos políticos, etc. Todo el mundo llama para que su versión de la realidad esté presente. Aunque nosotros no queremos calificar a todas esas llamadas como presiones, preferimos denominarlas intenciones comunicativas o voluntad de hacerse ver" (López, 2012: 34).

Desde la Teoría de la sociedad de masas, concretamente de la perspectiva de la Teoría de la Economía Política Crítica, los medios de comunicación sólo buscan el rendimiento económico y para ello aspiran únicamente a conseguir grandes audiencias que ofrecer a sus anunciantes, sin dar respuesta a las necesidades de la sociedad (Cisneros, 2002).

En cuanto a la concentración de medios, un número cada vez más reducido de empresas mediáticas son las que controlan todas las cabeceras de prensa, cadenas de televisión y radios del país.

"Los dos mayores consorcios europeos de televisión privada son RTL, del grupo alemán Bertelsman, y las plataformas Sky del Reino Unido, Italia, Austria y Alemania, participadas y lideradas por News Corporation, de la familia Murdoch". (Campos-Freire, 2013) 


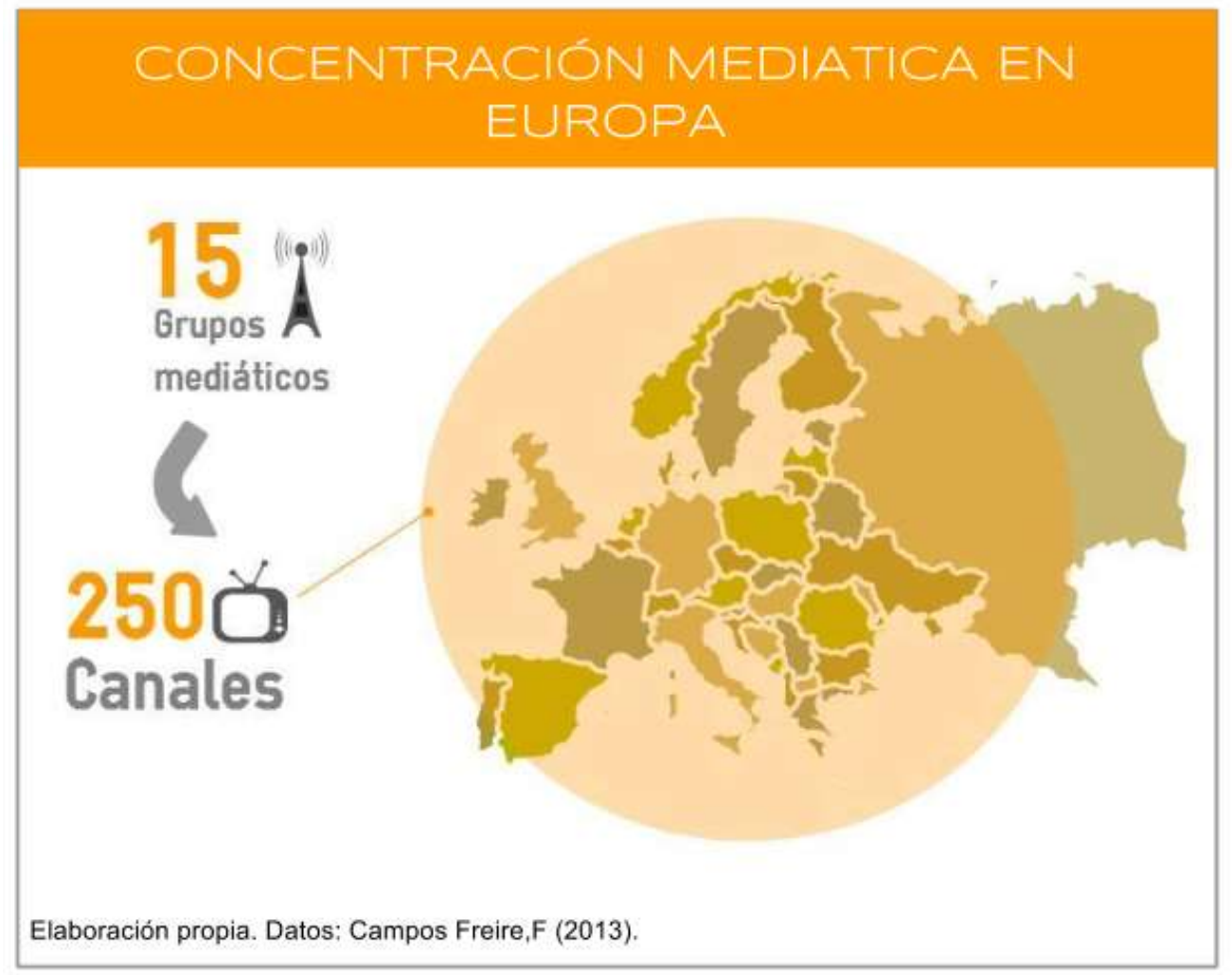

Ilustración 1. Concentración de medios en Europa

Los principales grupos mediáticos en España son Mediaset (Telecinco, Cuatro, FDF, La Siete, Boing, Divinity, Energy, Nueve), A3Media (Antena3, La Sexta, Nova, Neox, Nitro, Xplora, La Sexta3, Onda Cero, Europa FM ${ }^{6}$ ), Prisa (El País, Diario As, Cinco Días, Cadena Ser, Los 40 Principales, M80 Radio, Cadena Dial, Máxima FM y Radio Olé, Canal+, 40TV, 40Latino, Sportmania, Viajar y forma parte de Mediaset con un 18\% de acciones) y Unidad Editorial (El Mundo, Marca, Expansión, AXN, 13TV, Discovery Max, Orbyt TV, Popular TV, Radio Marca y esRadio).

Uno de los hitos en cuanto a concentración mediática de los últimos años fueron las fusiones de La Sexta y Antena 3, y por otro lado Cuatro y Telecinco en 2012. Estos hechos se produjeron tras la

\footnotetext{
${ }^{6}$ A3Media pertenece al grupo Planeta, uno de los grupos más grandes en todo el Mundo. Además de estos medios audiovisuales es propietario del diario La Razón, así como más de una treintena de editoriales; empresas de coleccionables, formación y venta directa en España y Latinoamérica.
} 
prohibición legal de participar significativamente ${ }^{7}$ en el capital social de varios operadores de televisión de forma simultánea.

El nuevo marco regulador propició nuevas estrategias como éstas, que extendieron el manto de acción de dos holdings de comunicación como Mediaset y A3media. Esta legislación sumada a la supresión de la publicidad en RTVE, marcaron el panorama mediático español. Además, hay que tener en cuenta el contexto de crisis en el que sucedieron estos hechos y en el que todavía estamos inmersos actualmente.

"La inversión publicitaria en esos años había sufrido unos descensos del 11\% y de más del 23\% (en 2008 y 2009, respectivamente). Una importante tendencia a la baja que se mantuvo en años posteriores.” (Pérez, 2013: 519)

A pesar de la caída en inversión publicitaria, como era de esperar, las televisiones privadas se beneficiaron de un aumento de anunciantes que no contaban con RTVE como espacio para publicitarse. Pero no todos los agentes de este negocio salían beneficiados. Los anunciantes comenzaron a temer un incremento de los precios en una situación de oligopolio, pues ya se vislumbraban las posibles fusiones. Si bien desde la UTECA (Unión de Televisiones Comerciales Asociadas) defendían las buenaventuras del libre mercado sin la intromisión de lo público en las reglas del juego del sector privado. Finalmente, así fue Mediaset y A3media poseen el 86\% de la inversión publicitaria. (Ibíd., 2013)

Por otro lado, el RD Ley 1/2009 posibilitó la concentración mediática suprimiendo la prohibición existente hasta el momento para poder participar en distintos operadores televisivos con un porcentaje significativo. Los únicos límites que contempla la legislación para no poder participar en varios medios son:

\footnotetext{
${ }^{7}$ La Ley General de Comunicación 7/2010 (Art. 33) establece por significativa la que represente indirecta o directamente: a) el 5\% del capital social; b) el 30\% de los derechos de voto o porcentaje inferior, si sirviera para designar en los 24 meses siguientes a la adquisición un número de consejeros que representen más de la mitad de los miembros del órgano de administración de la sociedad (Op. Cit.,2013)
} 
- Que la audiencia media del conjunto de los canales en los que se tiene participación (si son de ámbito estatal) supere el 27\% de la audiencia total durante los doce meses consecutivos anteriores a la adquisición.

- Que las empresas en las que se participa tengan derechos de uso sobre dominio radioeléctrico público superior con capacidad para dos canales simultáneos o uno si es de carácter autonómico.

- Que impida la existencia de al menos tres operadores televisivos privados de ámbito nacional.

De esta forma el Estado ha limitado las prohibiciones contra la concentración mediática, fomentando los oligopolios audiovisuales y reduciendo cada día más el pluralismo informativo. Por ello, los ciudadanos cuentan con menos opciones para elegir el entretenimiento e información que desean consumir.

Como consecuencia, la información que recibimos los ciudadanos se encuentra en las manos de apenas cinco o seis grupos mediáticos. Por tanto, a pesar de tener la impresión de que tenemos muchas opciones donde informarnos, la verdad es que la pluralidad de voces se ve reducida a la mínima expresión. 


\section{Control de la información política en las televisiones públicas}

廿 $\mathrm{N}$ el proceso de decisión de voto intervienen emociones, sentimientos y razonamientos, que se desarrollan a través de dos vías según Manuel Castells (2009): mediante el razonamiento enmarcado, o de manera exclusivamente emocional, según los marcos de Lakoff (2007).

Para el autor, los marcos "son estructuras mentales que conforman nuestro modo de ver el mundo", por lo que son nuestra base referencial a la hora de decidir, de creer, de interactuar en nuestro entorno, etc. No son algo físico, por lo tanto, sólo podemos intuirlos a través del lenguaje y el sentido común que muestra cada individuo.

Las estructuras o marcos de referencia de los valores familiares se extrapolan a las ideologías de los partidos conservadores o liberales en función de la manera en la que plantean su política y su idea de Nación y Estado.

Estos marcos también son utilizados por los medios de comunicación, sobre todo el miedo. Cuando una información se nos presenta desde la perspectiva del miedo nuestro cerebro se pone en alerta y presta mayor interés a dicha noticia. Por ejemplo, no es lo mismo decir que el paro ha aumentado un $26 \%$ en el último año, que decir que el crecimiento de empleo se ha reducido en el último año. La primera información resulta alarmante para cualquier ciudadano desde el momento en que puede afectarle a él mismo. Es una cuestión de lenguaje fundamentalmente, aunque también audiovisual. 
Otra estrategia mediática que influye en la toma de decisión electoral del ciudadano es la ampliación de la cobertura de los temas políticos, sobre todo en periodo electoral. Con este procedimiento, se aumenta la eficacia de los marcos de referencia pues aumenta el tiempo de exposición de la sociedad ante este tipo de contenidos.

Para Graber (2007), el enmarcado de la opinión pública se realiza a través de diversas técnicas: 'agenda setting' (los temas que seleccionan los medios), la indexación y el 'priming' (la priorización de los temas y su duración) y finalmente el 'framing' (el enmarcado). Todas estas prácticas influyen en el conocimiento que creemos tener sobre un tema y en nuestras emociones, ambos factores determinantes a la hora de tomar una decisión.

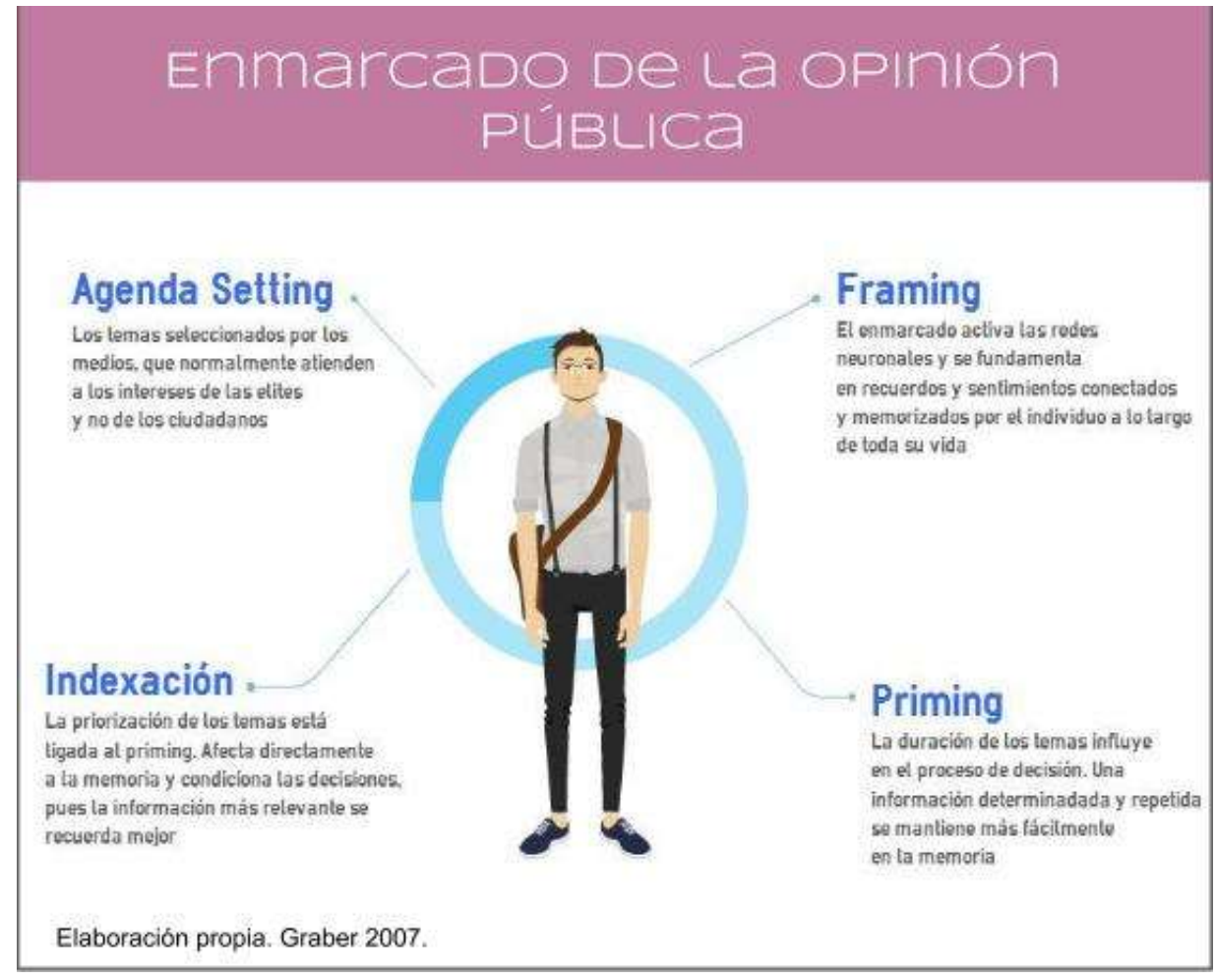

Ilustración 2. Técnicas del enmarado de la Opinión Pública de Graber.

Por otra parte, hay que tener en cuenta la teoría de los efectos del razonamiento motivado, que alega que cada individuo cree lo que quiere creer, es decir, busca información que reafirme sus convicciones. Además, esta tendencia aumenta cuanto más conocimiento tiene el sujeto sobre el tema en cuestión. Fundamentalmente, esto ocurre porque los electores están más condicionados por sus valores que por sus propios intereses, incluso 
la fidelización a un partido viene determinada por valores familiares o históricos. El enmarcado no es un sesgo sistemático, ya que puede ser premeditado o no (Castells, 2009: 212-221). La única forma de escapar a los enmarcados para Castells es adoptar un pensamiento crítico, dejar la actitud de consumidor de información y adoptar una posición de búsqueda de la misma a través canales no convencionales.

La televisión es el medio más poderoso a la hora de influir en nuestras decisiones ya que las ideas son imágenes en nuestro cerebro y la construcción de significados se hace a través de la creación de ellas, por eso en el ámbito de la política, los líderes que no están en los medios no existen para el público.

Sabemos que los medios no son los únicos factores que influyen en la decisión de voto, sin embargo, como afirma Castells (2009), los medios "son el espacio donde se crea el poder", pues no son neutrales, tienen sus propios intereses tanto políticos como económicos, ya que en definitiva son empresas. Por lo tanto, su intención reside principalmente en aumentar y afianzar su audiencia objetiva mediante el valor de su credibilidad. Como señalábamos con anterioridad, esto se transforma en un condicionante del propio medio de comunicación a la hora de ejercer las labores periodísticas de forma ética.

Según Yolanda Sobero ${ }^{8}$, ex presidenta del Consejo de Informativos de TVE, el pluralismo va más allá de lo que los partidos y la Ley Electoral entienden, puesto que:

“A los partidos lo único que les interesa es el tiempo. El 99,99\% de las denuncias viene por un reloj que marca que el señor correspondiente ha salido diez minutos u ocho y la oposición ha salido más y claro el tiempo es un factor, pero no es un factor de calidad, ni siquiera de pluralismo. A veces el peor favor que se le puede hacer a alguien, sobre todo en televisión, es sacarlo porque le dejas hablar y puede hundirse él sólo".

\footnotetext{
${ }^{8}$ Entrevista personal realizada el 03-11-2011 en los estudios de RTVE en Madrid.
} 
El ex miembro del Consejo de Informativos de TVE, Pedro Soler' apunta además la importancia de los criterios de la dirección de informativos, puesto que pueden confundir equilibrio con pluralismo y caer en presentar las dos versiones de forma sistemática, lo que conduce "al extremo, al paroxismo de que muchas veces sale un político y el otro, aunque no tenga nada que decir y siempre son los dos partidos políticos mayoritarios, PP y PSOE, eso no es pluralismo"

La política mediática según Castells, no sólo se lleva a cabo durante el periodo de campaña electoral, sino que es una tarea que se realiza día a día:

"Es el proceso continuado de información y difusión de imágenes relativas a la política lo que conforma la opinión pública de una manera difícil de alterar durante los momentos de mayor atención, a menos que se produzca algún acontecimiento o mensaje espectacular justo antes del momento de tomar la decisión."

Así lo confirmaba el ex consejero de Informativos de TVE, Pedro Soler:

"hay presiones, y los criterios del bloque electoral se utilizan por regla general durante todo el año", y a juicio de la ex presidenta del Consejo, Yolanda Sobero, se establecen estos repartos de tiempo porque "es lo más cómodo".

A pesar de que los procesos mediáticos se están homogeneizando mundialmente debido a la globalización, en cuanto a la profesionalidad y neutralidad podemos observar que impera un modelo generalizado. Sin embargo, existen diferencias en función de cada país y de su legislación electoral (Ibíd., 2009: 261-268), que igualmente se aprecian en la clasificación de Hallin y Mancini (2004).

Esta clasificación diferencia los medios dependiendo de: el desarrollo de los mercados de comunicación, las vinculaciones con la política, la

\footnotetext{
${ }^{9}$ Entrevista personal realizada el 03-11-2011 en los estudios de RTVE en Madrid
} 
profesionalización de los periodistas y el grado de intervención estatal sobre ellos.

- En primer lugar, se encontraría el modelo Mediterráneo (Pluralista Polarizado), en el que se halla España. Son medios con un interés muy político y hay tradición de periodismo de opinión. Además, es frecuente la instrumentalización de los medios por parte del Gobierno, partidos políticos, empresarios y financieros unidos a la política. El Estado es propietario, regulador y fuente de la financiación de los medios de comunicación que han sufrido una desregulación muy brusca dentro del espectro mediático.

- En segundo lugar, el modelo del norte y centro de Europa (Democrático Corporativo), cuyas características se fundamentan en la temprana aparición de la libertad de prensa y la industria de una prensa con grandes tiradas. El nivel de profesionalidad es alto, la libertad de prensa convive con una regulación de los medios por parte del Estado. La radiotelevisión pública suele seguir el modelo parlamentario o cívico/corporativo. La autonomía profesional en estos medios es considerable.

- Y finalmente el modelo del Atlántico Norte (Liberal). Se caracteriza por un desarrollo temprano de la libertad de prensa, aunque domina la prensa comercial. Profesionalización considerable, pero sin la organización formal del modelo anterior. Es más probable que la autonomía profesional esté amenazada por presiones comerciales que por una instrumentalización política. Predomina un periodismo orientado a la información.

En este modelo, la radiotelevisión pública y su regulación están organizadas según el modelo profesional. Están fuertemente aislados de un posible control político, por lo que el Estado tiene un poder limitado sobre los medios. Un claro ejemplo en el sector público sería la BBC. (López, 2012: 34, 35) 
No obstante, como ya hemos señalado, los medios de comunicación tampoco son el único factor que influye en la vida del ser humano y sus efectos, por tanto, también tienen limitaciones. Desde Lazarsfeld, abanderado de la teoría de los efectos limitados, hay una parte de los estudiosos de la comunicación que advierten de las limitaciones de los efectos que los medios de masas tienen con respecto a la creación de la opinión pública, en contraposición a la teoría de la aguja hipodérmica de Lasswell que atribuye a los medios de masas más poder de impacto sobre los ciudadanos.

Para los defensores de la teoría de los efectos limitados como Katz, la audiencia no está influenciada exclusivamente por los medios de masas, por lo tanto, el contexto es, en su conjunto, el responsable de la influencia que pueda tener el votante dependiendo de su edad, la familia, su pertenencia ideológica, etc. De este modo, la teoría concede a los ciudadanos una capacidad que los hace menos vulnerables que la concepción que tienen del público las teorías de sociedad de masas (Ferry et. al.1995:85-86).

Toda la teoría se sustenta en la exposición, percepción y retención selectivas que hace el individuo, siempre buscando información que ratifique sus propias opiniones, actitudes, creencias, valores $\mathrm{O}$ intereses. Este proceso se produce de forma consciente o inconsciente.

Por este motivo, los teóricos Katz y Lazarsfeld otorgan un poder decisivo a los líderes de opinión, que son el enlace entre los mensajes masivos y públicos. Como consecuencia, los medios no son omnipotentes, debido a que: los ciudadanos se relacionan en redes interpersonales y seleccionan los mensajes que reciben, perciben y retienen en su memoria. Desde la teoría de los efectos limitados se apuesta por la autonomía de la audiencia frente a los mensajes mediatizados, desechando la idea de que el público es dócil y pasivo ante ellos (Ferry et. al., 1995: 104,105).

La teoría de los efectos limitados concibe una audiencia heterogénea, formada por individuos que a su vez forman grupos dependiendo de sus elecciones. La comunicación se realiza en dos fases a través de los líderes de opinión, que son el nexo de unión entre los medios y los grupos de audiencia. Por lo tanto, los líderes moldean la información 
antes de llegar a los individuos y transforman la comunicación vertical mediática, en comunicación horizontal entre los grupos.

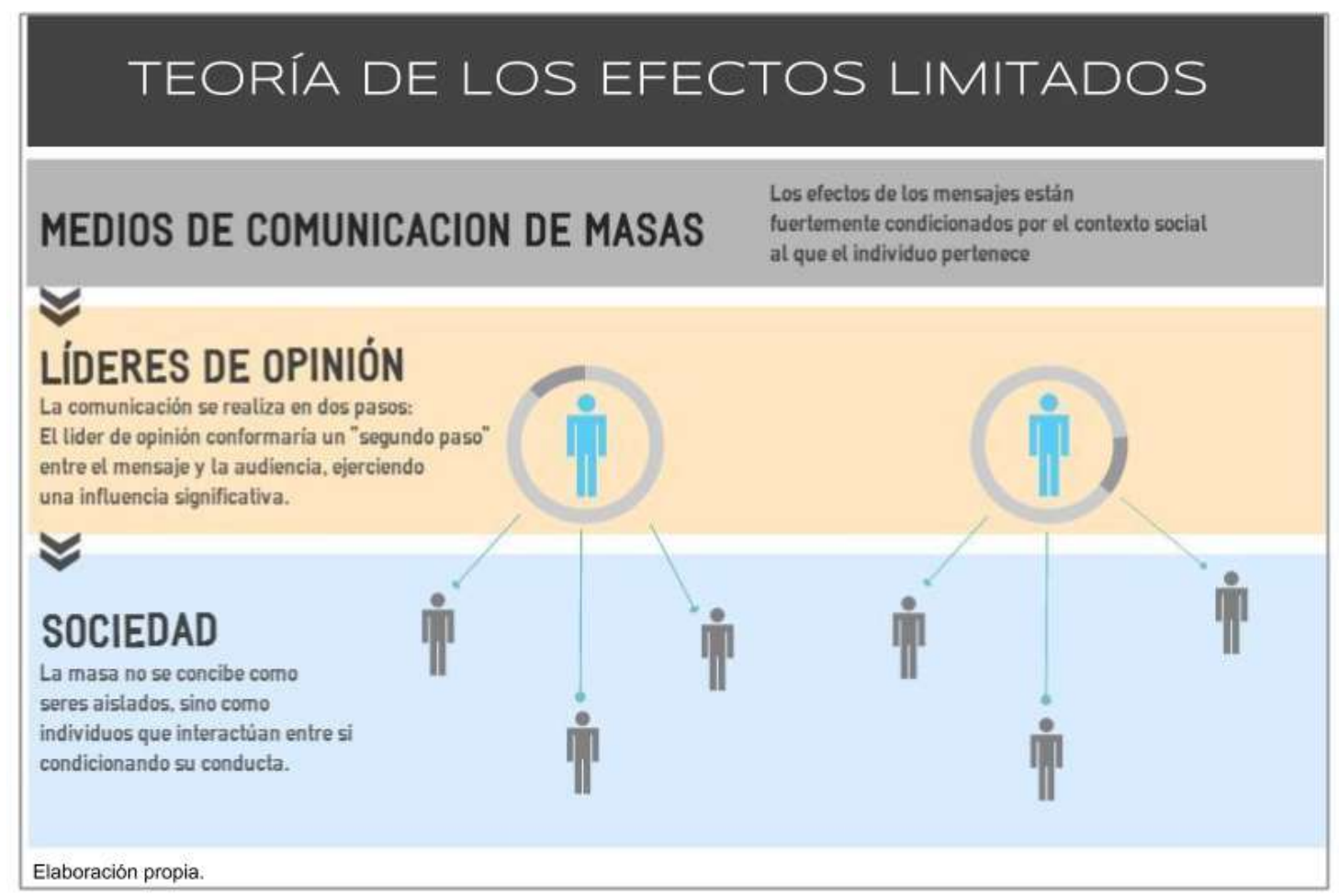

Ilustración 3. Teoría de los efectos limitados

Como resultado, autores como Klapper concluyen en sus investigaciones que la comunicación de masas persuasiva refuerza las opiniones más que modificarlas, en gran medida debido al entorno y algunos factores que envuelven dicha comunicación. Por lo tanto, es posible crear opinión si el público no tiene ningún juicio previo o no está a favor o en contra del tema en cuestión, pero si ya existe una opinión formada, sólo contribuirá a su refuerzo.

Sin embargo, las críticas más importantes a la teoría de los efectos limitados recaen en: su abuso del laboratorio en los estudios, medir los efectos de la persuasión sólo a corto plazo $^{10}$ y la pérdida de importancia de la figura del líder de opinión en la era de Internet (Muñoz et. al. 1990:245-251).

Lo que sí es incuestionable es el poder que tienen los medios de comunicación en nuestra sociedad, sobre todo la televisión e Internet.

\footnotetext{
${ }^{10}$ Mario Caciagli advierte que la persuasión en televisión es un proceso constante y a largo plazo.
} 
Aunque el primero es sin duda el medio preferido de la sociedad para informarse. La televisión agrupa ciudadanos de todas las edades y franjas socio-económicas, mientras que Internet tiene las limitaciones de la brecha digital ${ }^{11}$, pues las personas mayores y sin recursos no lo suelen utilizar.

Por tanto, la televisión es un medio muy influyente, también y más si cabe, durante los periodos electorales, pues transforma la realidad en una representación mediatizada más simple; se crea un espacio público virtual, no real, alejado de los problemas e intereses de la sociedad; y convierte al ciudadano en un mero espectador que no ejerce ninguna acción en la vida pública, sino que es un sujeto pasivo que consume un relato (Ortega, 2011:33-39).

Partiendo de la idea de que la televisión debe ejercer un servicio público, las cadenas de titularidad pública deberían: ser instituciones autónomas, no gubernamentales e independientes de los poderes, para ser perro guardián ${ }^{12}$; estar financiados públicamente sin condicionantes, por un canon de los propios usuarios, o la publicidad regulada sin atentar contra la competitividad en el mercado; respetar los principios de universalidad, continuidad, versatilidad y adecuación; y finalmente ofrecer calidad real y satisfacer necesidades sociales, educativas, culturales, de ocio y total accesibilidad para los ciudadanos (Pascuali, 2007:288).

\footnotetext{
11 "La brecha digital se define como la separación que existe entre las personas (comunidades, estados, países...) que utilizan las Tecnologías de Información y Comunicación (TIC) como una parte rutinaria de su vida diaria y aquellas que no tienen acceso a las mismas y que aunque las tengan no saben cómo utilizarlas" www.labrechadigital.org

${ }^{12}$ El papel de un periodista como 'Watchdog', es proveer a los ciudadanos la información que deben tener para evitar el abuso de poder y alertarlos sobre aquellos que están actuando en contra de sus intereses. Para que los periodistas puedan ser vigilantes del poder deben tener cierta distancia con el mismo y por tanto de las elites. Debido a esta separación del poder y su función supervisora, se denomina al periodismo como cuarto poder. La temática que el periodismo vigilante abarca incluye: escándalos personales, delitos financieros, la corrupción política, el enriquecimiento en la función pública y otros delitos.
} 
Podría considerarse que la televisión es el medio de comunicación más democrático, pues es accesible para la mayoría, con su espectacularidad la política es menos elitista, el elector medio accede más fácilmente a los programas electorales, fomenta los lazos sociales en el nuevo espacio público. Sin embargo, para autores como Regis Debray, la televisión "despolitiza la política, desmotiva al elector, desresponsabiliza al responsable y fomenta peligrosamente la personalización del poder".

Según Debray la imagen desbanca a la palabra y ahora es ley. Los políticos son conscientes y por ello dedican mucho esfuerzo en aparecer en televisión. Para conseguirlo le dan más importancia al medio que al mensaje y aparecen en el espectáculo televisivo junto a cualquier otro personaje mediático, a costa de perder su legitimidad como clase política mediática. En definitiva, llevando a la ciudadanía a la desmotivación política.

En este sentido, el ex editor de TVE, Miguel A. Hoyos, considera que actualmente:

"Es muy difícil diferenciar entre informativos y magazines en muchos casos; quedan muy pocos informativos de televisión que realmente lo sean y la frontera hacia el magazine, hacia el programa de entretenimiento, se cruza demasiadas veces para conseguir más audiencia. En cambio si las cosas se hacen bien la gente tiene interés en la información política".

La televisión tampoco es un adalid de igualdad, puesto que producir imágenes cuesta mucho más que producir textos. No todo el mundo tiene medios económicos para estar en la televisión y esto genera una desigualdad social entre los que aparecen en ella y los que no, los conocidos y los desconocidos para la sociedad. Esto atañe desde a los partidos políticos hasta asociaciones ciudadanas, culturales, religiosas...

La regulación de los contenidos por las preferencias de la audiencia es otro factor característico de la televisión actual y que, sin duda afecta al pluralismo informativo, pues reduce al denominador común la 
pluralidad de la sociedad, dejando fuera a las minorías (Debray, 1994:279-282).

Así lo cree también Enrique Bocardo Crespo quien afirma que la democracia es un sistema gubernamental:

"Cuya eficacia se basa en la creación, el manejo y control de la opinión pública. Es gobierno de mayorías, el gobierno de la opinión mayoritaria que inevitablemente es dictada por los centros de decisión afines a los intereses del poder" (Badillo, et al., 2003:95, 96).

Ante estas prácticas comunes que desembocan en una realidad sesgada e incompleta, es lógico pensar que el consumo de información únicamente a través de la televisión es insuficiente para tener una idea aproximada de la realidad. Esto se traslada también a los periodos electorales donde la información a la que accede el votante está seleccionada de acuerdo a distintos intereses de los medios, por este motivo su influencia será conscientemente dirigida por los mismos buscando favorecer al partido con el que simpatiza.

Con todo, hay profesionales como Miguel A. Hoyos, que apuestan por la información de calidad. Cree que las televisiones buscan lo fácil, lo previsible y se escudan en darle a la audiencia lo que supuestamente quiere, espectáculo, "nos estamos mintiendo a nosotros mismos. Y prueba de ello son éxitos de programas de información política como 'Tengo una pregunta para usted', con gran respaldo de la audiencia".

Por todos es sabido que los partidos políticos mantienen una estrecha relación con los medios de comunicación, pero sobre todo con la televisión, por su gran alcance en la población. Durante las campañas electorales este trato se intensifica y surgen dependencias entre ambas partes:

Por un lado, la televisión está inmersa en esa competición por tener las mismas informaciones que las otras cadenas y no por desmarcarse y quiere mantener a los políticos cerca para que no se escape ninguna información que pueda obtener posteriormente la competencia. Sin embargo, los partidos saben que las grandes audiencias de la 
televisión son fundamentales para acceder a gran parte del electorado y darse a conocer, dejarse ver, para tener opciones a la mayoría de votos (cit. Grijelmo, Berrocal, 2003:139).

Por este motivo, "lo primero que hace un partido político cuando accede al poder es controlar el gigantesco aparato estatal de propaganda política", para lograr movilizar la opinión pública a su favor y así conseguir mantenerse en el poder (Op. Cit. 2003: 96).

Según la ex-editora de TVE, Pepa Rodríguez:

"a los políticos en general les interesan las televisiones públicas en cuanto les sirvan para algo. Creo que una de las cosas que Zapatero hizo bien, que es una promesa que cumplió, fue despolitizar y desgubernamentalizar la televisión pública, pero es una marcianada" (López, 2012).

Las campañas han ido evolucionando desde que se estableció el sufragio universal, dependiendo de la tecnología que ha ido surgiendo. Aunque actualmente Internet está creciendo como canal para seguir las campañas electorales, la televisión es el medio más consumido por los ciudadanos, a veces, incluso el único. Por ello, los partidos trazan fundamentalmente una estrategia televisiva centrada en las noticias, las entrevistas, los debates y los anuncios publicitarios.

En relación a las noticias electorales, tratan de enseñar al público la actividad del partido en campaña ese día (Berrocal, 2003:138). Son una forma imprescindible para llegar al electorado, consecuentemente los partidos políticos muestran un gran interés por contactar con los periodistas, de hecho, en campaña, los partidos persiguen a los medios de comunicación, al contrario de lo que se podría pensar. Según Grijelmo (Ibíd., 2003:138-139), "la campaña televisiva legitima al partido y en el caso hipotético de que un partido no aparezca en televisión o aparezca menos de lo aconsejable se deslegitimaría". Por este motivo, y por las grandes audiencias televisivas, los políticos, y sobre todo en campaña electoral, necesitan de los medios más que nunca.

En el caso de Canal 9 sabemos que los actos de campaña se pactan con los partidos políticos, según fuentes consultadas. Mientras que en 
La 1 todos los periodistas entrevistados para la investigación, afirmaban ser libres de cubrir los actos que consideraran bajo criterios exclusivamente profesionales (Op. Cit. 2012).

Es importante saber, que en ocasiones los medios, en su intención de cumplir con su tarea de servicio público, realizan acciones que benefician los intereses partidistas. En estos casos, los medios de comunicación se dejan llevar por las técnicas del marketing político, ensalzando y comparando cualquier proceso electoral con los comicios generales. Esa referencia nacional se extiende a toda la población y a los propios políticos, fomentando la personalización y la presidencialización de la política. (Molins, et. al., 2006:223-240).

En este sentido, los medios de comunicación intentan ser neutrales, por eso acaban mostrando todas las partes y caen en el periodismo de declaraciones, convirtiéndose en meros canales de la información que los partidos quieren transmitir.

Aunque la personalización de la política es natural, pues la política la hacen personas y visibilizar en una persona las ideas facilita la comprensión de conceptos, según Martín Salgado, retransmitir las declaraciones de los políticos al electorado siendo un mero canal de comunicación, no muestra la verdadera personalidad del candidato, sino que la sociedad conoce la imagen que los 'spin doctors' ${ }^{13}$ han diseñado para su líder de partido.

Para la periodista Ana Pastor, la personalización "me suena a veces a espectáculo, me da un poco de miedo, no sé muy bien donde está el límite y creo que deberíamos medirlo”.

En general los medios abusan de los datos de encuestas, cubren las elecciones como una 'crítica del teatro" ${ }^{\text {"14 }}$ sobre lo que éstas suponen, reducen los tiempos de discursos a favor de la interpretación y la personalización, y de este modo, confunden los conceptos de

\footnotetext{
${ }^{13} \mathrm{El}$ spin es un tipo de propaganda dentro de las relaciones públicas. Los `spin doctors' son los encargados de organizar esta propaganda para manipular a la opinión pública.

${ }^{14}$ Término acuñado por Kuki Adatto (1990) haciendo referencia al periodismo que "informa más del arte escénico de la sustancia" (Molins et. al., 2006:226)
} 
independencia y neutralidad. Cayendo en la vehemencia que denuncia el Consejo de Informativos de TVE.

Suelen confundir independencia con neutralidad porque la objetividad no existe y su influencia personal es inevitable. Aunque el problema reside en la falta de transparencia o de independencia.

En realidad, un medio independiente tiene una opinión y se posiciona en los asuntos, e inevitablemente intenta convencer al público de su opción. Por otra parte, un medio dependiente no sólo toma parte, sino que su objetivo es vencer electoralmente, intentando mantener su reputación como independiente confundiéndola con la neutralidad, de este modo no es partidista abiertamente y persuade al público haciéndole creer que está tomando sus decisiones sin ningún tipo de influencia (Molins et. al. 2006: 225-239).

No obstante, el uso de los sondeos reduce el sentido de la campaña electoral exclusivamente a los datos y la convierten en una competición donde lo más significativo es quién gana y quién pierde.

Sabiendo que los medios tienen un espacio físicamente limitado, el problema de ocuparlo en exceso con los sondeos se debe al dudoso carácter informativo de éstos y porqué desplaza o elimina la información elaborada de forma tradicional, que es la que realmente concierne a los ciudadanos. Si bien, para Martín Salgado las noticias sobre sondeos aumentan porque "son fáciles de obtener, permiten una narración sencilla, tienen el gancho de la novedad y ofrecen la posibilidad de decir que la interpretación periodística de la campaña se basa en datos" (Molins et al., 2006:225).

La información en campaña está ligada a la teatralidad, a la espectacularidad y muchos creen necesario este entretenimiento para aumentar el interés de los ciudadanos por la política. Por otro lado, los medios no pueden sucumbir a estos artificios para finalmente, consciente o no, favorecer los intereses de los partidos, puesto que la información se queda en los aspectos técnicos, escenográficos y superficiales de las campañas. Los periodistas tienen acceso a la trastienda de los partidos y frecuentemente presentan la información como espontánea, cuando en realidad está absolutamente planificada por el marketing político. 
Observando la complejidad del tratamiento informativo de unas elecciones, la legislación española establece como deben ser las rutinas productivas en televisión durante las campañas electorales, concretamente se regulan a través de la L.O. de Régimen Electoral General (LOREG), que estipula en su artículo 66.1 que:

"El respeto al pluralismo político y social, así como a la igualdad, proporcionalidad y la neutralidad informativa en la programación de los medios de titularidad pública en periodo electoral, serán garantizados por la organización de dichos medios y su control previstos en las leyes."

Además, hace referencia a los medios de comunicación privados, a los que el artículo 66.2 insta a:

“(...) respetar los principios de pluralismo e igualdad. (...) también los principios de proporcionalidad y neutralidad informativa en los debates y entrevistas electorales, así como en la información relativa a la campaña electoral de acuerdo a las Instrucciones que, a tal efecto, elabore la Junta Electoral Central."

El proceso comienza cuando la televisión presenta el Plan de cobertura a la Junta Electoral Central (JEC), donde una Comisión de Radio y Televisión, aprueba dichos planes antes de la llegada de la campaña electoral. Esta comisión se halla bajo la dirección de la JEC y está compuesta por un representante de cada partido que concurra a las elecciones y que ya posean representación parlamentaria de los comicios anteriores. De este modo, los votos de los integrantes de la comisión, serán proporcionales a la composición de la Cámara en las últimas elecciones.

En cuanto a los espacios publicitarios durante la campaña electoral, en España no se pueden vender a los partidos políticos libremente, pues según el artículo 63 de la L.O. 5/1985 de Régimen Electoral General es la JEC quien se encarga de distribuir dichos espacios según la representación parlamentaria que obtuvo cada partido en los comicios anteriores. En el caso de partidos sin representación tienen 
acceso a un mínimo de tiempo según el número de provincias en las que se presentan sus candidatos ${ }^{15}$.

Igualmente, estos espacios publicitarios son gratuitos y pertenecen exclusivamente a las televisiones públicas, ya que las privadas no pueden vender este tipo de espacios, como recoge la Ley anteriormente citada y en la derogada L.O. 2/1988 ${ }^{16}$.

En España estos anuncios normalmente suelen emitirse después de los informativos. En general tienen un formato que realza la figura del candidato y personaliza la imagen del partido en la de su líder. Por ello tiene un carácter humano que produce una mayor identificación del electorado con el mensaje del partido. Por este motivo, es importante que el anuncio muestre la personalidad del candidato, presente las propuestas del partido y al final de la campaña electoral, utilice la publicidad negativa de forma más agresiva contra la oposición.

Por lo que respecta a la información electoral, la LOREG es más precisa a la hora de establecer cómo y cuánto tiempo le corresponde a cada partido. De este modo, los espacios informativos electorales se regulan a través del artículo 66 y a los principios de proporcionalidad que cada partido tiene en el Congreso de los Diputados.

En cambio, la JEC deja claro en algunas de sus resoluciones que la proporcionalidad no es matemática, pues esto llevaría a minutajes sin sentido en los informativos televisivos, como afirma también el ex director de Programación y Gestión de Informativos de TVE, Xavier Obach:

"La proporcionalidad debe entenderse en la totalidad de la campaña, porque si entendemos la proporcionalidad en términos de un sólo día, incluso de un sólo informativo nos

\footnotetext{
${ }^{15}$ Según el artículo 64.2 de LOREG, tendrán derecho a los espacios publicitarios gratuitos, los partidos que presenten candidaturas en más del 75\% de las circunscripciones comprendidas en el ámbito de difusión o programación del medio.

${ }^{16}$ Ley Orgánica 2/1988, de 3 de mayo, reguladora de la publicidad electoral en emisoras de televisión privada, cuya vigencia se extinguió el pasado 30 de enero de 2011.
} 
encontraríamos con situaciones absolutamente kafkianas, como que habría partidos que aparecerían un segundo, lo cual es inverosímil."

En cuanto a las entrevistas, en los últimos años se aprecia una tendencia que sigue el modelo estadounidense, como las apariciones de los candidatos en magazines, talk shows o late night shows ${ }^{17}$. En este tipo de programas el político utiliza un discurso más relajado y trivial, debido al carácter desenfadado de esta clase de espacios, donde el presentador no suele interrumpir o hacer preguntas comprometidas. Con estas apariciones consiguen llegar a una gran cantidad de espectadores que buscan en la televisión meramente una forma de entretenimiento, pues está perdiendo interés por los temas públicos de máxima relevancia.

A propósito de los debates, España no tiene una gran tradición en este género. En 1993 se realizó el primer debate electoral en España. Tuvo lugar entre Felipe González y José M. ${ }^{a}$ Aznar en una cadena privada cuya cuota de audiencia se disparó.

Cabe destacar que "el debate se articula como una confrontación entre dos políticos cuya única finalidad es convencer y llegar al público a través de sus argumentos. Por tanto, los telespectadores se convierten en el tercer actor, el más relevante" (Quintas, 2010:29).

De esa forma, una audiencia grande significa un gran número de votantes que pueden ser convencidos para dar su voto a uno u otro candidato. Prueba de dicha importancia se refleja en la audiencia que tuvo el debate entre Zapatero y Rajoy en febrero de 2008, que fue seguido por más de trece millones de telespectadores ${ }^{18}$.

\footnotetext{
${ }^{17}$ Montilla, apareció en el late night de Buenafuente (La Sexta) el día 22 de noviembre de 2010. (Una semana antes de las elecciones autonómicas catalanas). Y claro ejemplo han sido las Elecciones Generales de 2015 donde los candidatos de PSOE, Podemos, Ciudadanos, incluso Soraya Santamaría del PP han ido a programas de entretenimiento como "El Hormiguero"

${ }^{18}$ Audiencias.info. "Éxito de audiencia del debate ZP-Rajoy". Recuperado el 1 de marzo de 2014 de:

http://www.audiencias.info/2008/02/26/exito-de-audiencia-del-debate-zprajoy/
} 
Durante la campaña electoral de 2011, se realizó un único cara a cara entre Rajoy y Rubalcaba, se eligió la Academia de las Ciencias y las Artes de Televisión como escenario neutral. Este hecho no fue bien recibido en el Consejo de Informativos de TVE, que recuerda que en el resto de Europa las televisiones públicas son el escenario para estos debates, además entienden que:

"Si estás acusando de manipulación a unos informativos y a una empresa en general pues lógicamente sería una incoherencia por tu parte. Pero, ¿qué fundamento tiene que hagas eso cuando esta empresa, estos informativos y esta casa en general es la mejor valorada por la audiencia? Tiene un grado de aceptación que debería ser tenido en cuenta por los responsables públicos para elegirlo como el medio idóneo para hacerlo.” (López, 2012)

La imagen emitida por la Academia pudo ser adquirida por todos los canales que así lo quisieron, A pesar de ello, el 'Cara a Cara' provocó las quejas de los partidos de la oposición con representación parlamentaria como IU, CIU, UPyD, etc. ya que no tuvieron la posibilidad de participar en él y perdieron la oportunidad de ser vistos por doce millones de ciudadanos. ${ }^{19}$

Algunas cadenas privadas realizaron entrevistas con líderes políticos y La 1 de TVE, además organizó un debate con las cinco fuerzas parlamentarias con grupo propio, en el llamado 'Debate a 5'.

Los debates suscitan mucho interés para los ciudadanos ya que pueden comparar al mismo tiempo las posturas, ideas e imágenes de varios candidatos y en definitiva de partidos opuestos. Para los partidos su intervención busca afianzar a sus votantes y convencer a los indecisos para ganar su voto (cit. Perloff, Quintas, 2010).

En España no se conciben como en EE.UU. donde tanto el moderador como la propia ciudadanía, representada en el público,

\footnotetext{
19 “Según Kantar Media, al menos 22.300.000 de personas contactaron en algún momento con la retransmisión en algunas de las cadenas. El canal más visto fue La 1 de TVE, con 5.485.000 espectadores y 24,8\% de cuota de pantalla" (Casado Ruíz, 2011).
} 
tiene un papel importante en el mismo. Esta es otra de las reivindicaciones del Consejo de Informativos de TVE, que denuncia que:

"El moderador no modera, simplemente va repartiendo el tiempo. Entonces hemos convertido todo el debate político en cualquier cosa menos en debate, por ejemplo, en una tertulia sientas al que sea y ves el reparto, teóricamente llevas periodistas, pero los miras y están elegidos en función del grupo mediático al que pertenecen y a la tendencia de ese grupo mediático, con lo cual ahí ya no estamos hablando de periodismo estamos hablando de otra cosa".

En referencia a los debates en Canal 9, se emitieron en diferido y a las 23:30 horas, lo que suscitó las críticas de la oposición pues entendían que existía una clara voluntad de reducir el interés de los mismos, para que no fueran vistos por la audiencia. Además, el diputado de EUPV, Iganci Blanco apuntaba que la LOREG no indica nada sobre cómo realizar los debates, por ello hacer "una reforma legal, probablemente sea lo que hace falta, porque la Ley actual está hecha en los años 80 cuando no había debate en televisión".

Tanto en los debates en Canal 9 y La 1 durante las elecciones de 2011 analizadas, los presentadores fueron meros conductores, que otorgaban el turno de palabra a los correspondientes candidatos, sin realizar preguntas. Simplemente, enunciaban la temática de los bloques que conformaban el debate y que habían sido pactados previamente entre la cadena y los políticos.

La personalización en España no recae en conocer la vida del candidato, como ocurre en EE.UU., las informaciones sobre su vida privada son algo anecdótico que humaniza la política. Por el contrario, la máxima expresión de la personalización política en España se encuentra en el periodismo de declaraciones, del que se abusa tanto a través de las manifestaciones que realizan los propios políticos, como con la cobertura que los medios realizan de dichas declaraciones. No hay que olvidar que las declaraciones son importantes en política, siempre y cuando la afirmación del político tenga un valor informativo real por lo que manifiesta. 
En definitiva, los medios de comunicación en España ven las campañas electorales como un teatro y en lugar de centrarse en criticar las técnicas del marketing político, caen en su espectacularidad. En la mayoría de las campañas encontramos que las "estrategias electorales acaparan la atención como novedad noticiosa", sirviendo a los intereses de los partidos y dejando al margen la información relevante (Molins et. al., 2006:226, 238).

\section{Las campañas electorales estadounidenses como máximo exponente}

El gran modelo a seguir a la hora de realizar las campañas electorales es Estados Unidos. El país está lleno de expertos y precursores del marketing político, que desarrollan su trabajo en una tupida red formada por cientos de canales, mayoritariamente privados. Esta situación, deja a la televisión pública norteamericana en un segundo plano, sin especial relevancia, para una audiencia abrumada por la oferta privada. Sin embargo, la historia de la televisión está íntimamente ligada a este país de marcado carácter de espectacularización.

En 1952 surgió la National Educational Televisión (NET) que no tenía un futuro muy prometedor, puesto que estaba financiada por donativos de su audiencia. A continuación, en 1967, bajo el mandato de Johnson y gracias a aportaciones de fundaciones como Ford o Carnegie, nació una nueva televisión pública en EE.UU. con el nombre de Corporation Public Broadcasting (CPB). Actualmente, aunque es una corporación no lucrativa y no gubernamental, el gobierno es quien la financia anual o bianualmente con la aprobación del Congreso.

Sin embargo, con el control de las estaciones en manos de diversas empresas, el margen de maniobra para la CPB fue muy reducido. Un año después y con una nueva aportación de la fundación Ford, se creó una empresa privada, no lucrativa, que a modo de cooperativa aunó a las estaciones televisivas bajo el nombre de Public Broadcasting Service (PBS).

Finalmente, y para limitar la concentración de poder de una misma estación, se creó la empresa independiente NET, que se encargaría de 
la producción y distribución de contenidos. Tras fusionarse, pasó a denominarse WNET-TV (Sánchez, 1991:38-42).

De este modo, el servicio público de televisión norteamericano sigue siendo, hasta el momento, una red de televisiones públicas de diversa índole, con 169 operadores de licencias educacionales no comerciales $^{20}$ que operan 348 estaciones de televisión. Además de las características propias de la industria mediática estadounidense, pionera históricamente.

Finalmente, la distribución de fondos públicos la realiza la $\mathrm{CPB}$, mientras que la PBS es el organismo encargado de agrupar este conglomerado de estaciones.

A su vez, el sistema electoral de EE.UU. se fundamenta en su Constitución, de hecho, de las veintiséis enmiendas que se han aprobado desde su proclamación en 1787, más de la tercera parte hacen referencia al sistema electoral federal. Un sistema electoral indirecto, en el que, a través de elecciones primarias en los estados, se eligen a los representantes que a su vez volverán a presentarse en el congreso nacional de su partido y si son elegidos, serán los candidatos para las elecciones generales.

El hecho de que tengan un sistema electoral indirecto, condiciona el modo en que los medios de comunicación establecen sus rutinas productivas en cuestiones

electorales,

El marketing político moderno en EE.UU. se inicia en los comicios de 1952 entre Eisenhower y Stevenson, donde los Republicanos comenzaron a darle importancia al discurso político, simplificándolo y aplicando técnicas de venta. Además, tuvieron en cuenta la imagen de su candidato, tanto en el aspecto físico como en pequeños detalles ante la cámara: no leer los discursos, o aparecer con mascotas como hizo Nixon para explicar que no había cometido cohecho.

En 1956 surge la publicidad comercial como herramienta, se acortan los anuncios electorales y se sitúan lo más cerca posible de programas

${ }^{20} 86$ pertenecen a organizaciones comunitarias, 57 de colegios o Universidades, 20 de autoridades estatales y 6 de autoridades locales o municipales. 
con grandes audiencias. Los republicanos vuelven a innovar, realizando por primera vez los spots negativos en el que presentan a su oponente de forma crítica (Maarek., 1997:28-31).

Estudios realizados en EE.UU. donde la mitad del presupuesto de campaña se emplea en la publicidad, afirman que, partiendo de una situación de igualdad entre los partidos, "la publicidad desplegada, dentro de una estrategia de bombardeo mediático coordinado con la generación de noticias, puede marcar la diferencia entre la victoria y la derrota" (Berrocal, 2003:144).

Por otra parte, la personalización de la política en Estados Unidos tiene como objetivo conocer la vida privada del candidato, tanto del pasado como del presente, siendo beneficioso para la oposición cualquier escándalo (Molins et. al., 2006:238).

Otra aportación de los estadounidenses al marketing político son los debates, desde el primer debate televisado entre Nixon y Kennedy en la campaña electoral de 1960, nadie duda de la importancia de esta forma de acercarse al electorado. Está demostrado desde los años ochenta, tras un estudio de la Universidad de Michigan, que más de la mitad de la población votante tuvo en cuenta la información electoral proveniente de la televisión (Berrocal, 2003:144). Esta conclusión sigue imperando actualmente, tal y como lo exponen los trabajos de Katz y Feldman en su obra 'The Debates in the Light of Research: a Survey of Surveys'.

Con el debate Nixon-Kennedy, 1960 puede considerarse el año del nacimiento de la comunicación política moderna, comenzando una tradición, que al contrario que en España ${ }^{21}$, ha tenido mucha importancia tanto para los expertos en comunicación política como para los líderes políticos, quienes conocedores de los riesgos que entrañan los debates, han decidido no exponerse ante el electorado en algunas ocasiones, como sucedió en el periodo comprendido desde las elecciones de 1964 hasta $1972^{22}$.

\footnotetext{
${ }^{21}$ Donde hemos asistido a cinco debates desde el inicio de la Democracia.

${ }^{22}$ Desde 1980 los debates en EE.UU. se realizan con regularidad.
} 


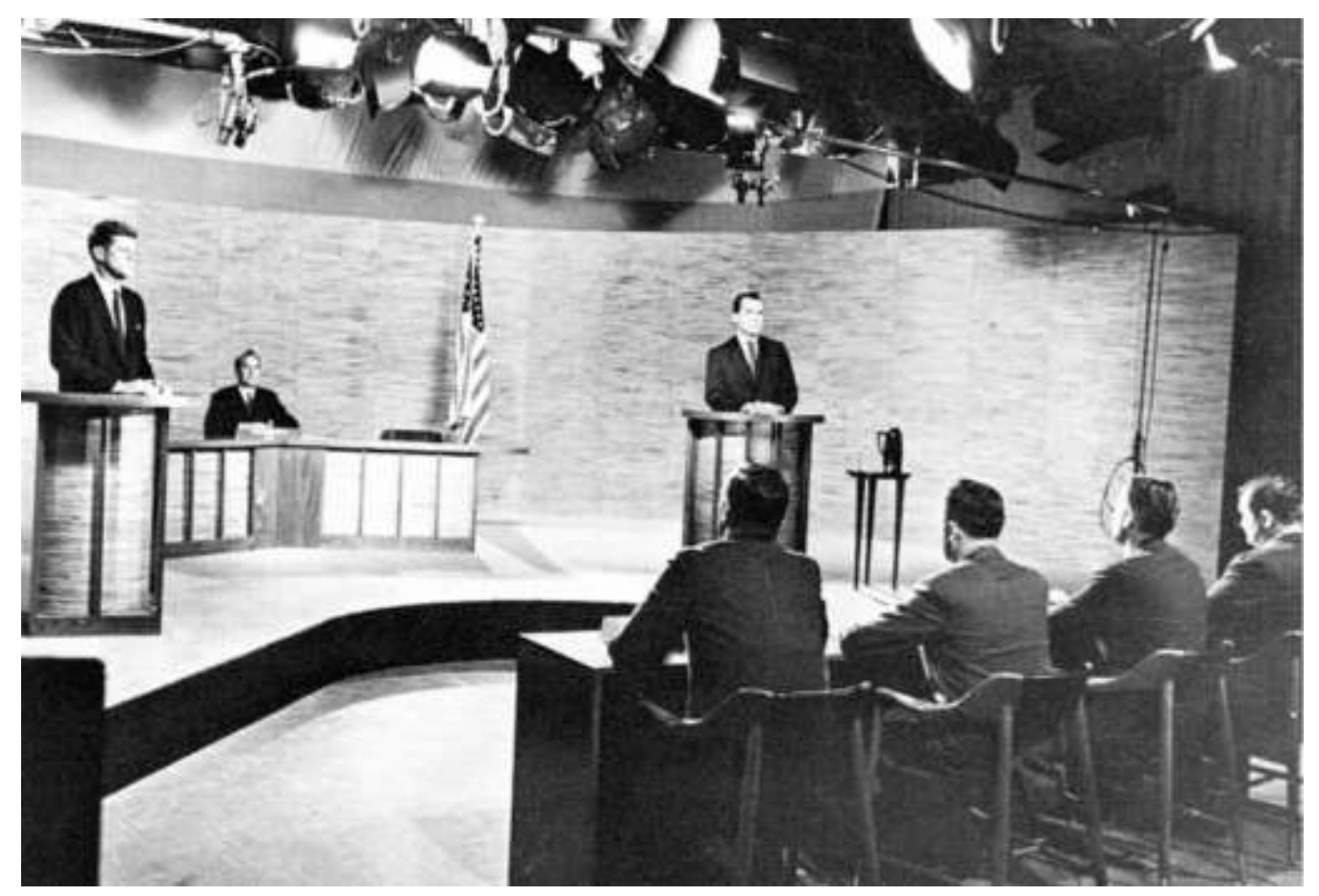

Imagen del debate Nixon - Kennedy en $1960^{23}$

Durante los años setenta, surgieron anuncios televisivos en los que el texto largo era el protagonista, pero la comunicación política maduró con la reanudación de los debates televisados y las facilidades para la publicidad política, que provocaron una mayor presencia de los anuncios electorales en televisión. En la década de los ochenta la televisión se consolidó como el medio más utilizado para informarse, por ello casi la mitad de los fondos federales que recibían los candidatos eran destinados a espacios televisivos; de ahí que el Tribunal Supremo limitara el gasto que los candidatos pueden hacer del fondo estatal. Este hecho ha empujado a los partidos y candidatos a la autofinanciación, por lo que en EE.UU. las campañas electorales alcanzan cifras astronómicas.

Estas técnicas de marketing político han sido utilizadas en la mayoría de sistemas electorales democráticos, esto se debe fundamentalmente al desarrollo de los medios de comunicación de masas en estos países. También lo ha fomentado la legislación en periodo electoral y el grado de desarrollo del país, aunque no se trate de un factor

\footnotetext{
${ }^{23}$ Imagen con licencia abierta consultada el 12-05-2014 en http://upload.wikimedia.org/wikipedia/commons/5/50/Kennedy Nixon De bat (1960).jpg
} 
concluyente pues hay países desarrollados con un nivel bajo en técnicas de comunicación política y viceversa (Op. Cit. 1997:33-38).

Cabe decir que la prensa norteamericana está más sensibilizada con el marketing político debido a su larga experiencia, y es mucho más perspicaz con las sutilezas del mismo. Actualmente, las campañas norteamericanas se cubren con el objetivo de desmontar las estrategias y técnicas persuasivas de los partidos. Por el contrario, con este empeño lo que consiguen es servir a los intereses de los partidos y a las mismas estrategias de campaña de las que hablan (Op. Cit. 2006:226).

\section{Tratamiento informativo en La 1 y Canal 9 durante las elecciones de 2011}

Las diferencias de gestión de la RTVE de Fran Llorente (2004-2008) y la RTVV de Luis Motes (2002-2007) o Lola Johnson ${ }^{24}$ (2007-2010), son abismales. Mientras la primera consiguió ciertos niveles de independencia entre sus profesionales, como elegir qué actos se cubrían en campaña electoral, en el ente valenciano no sólo se pactaban los eventos que iban a emitir con los partidos, sino que vetaban a ciertos políticos del propio PPCV o se informaba intencionadamente de las visitas sectoriales ${ }^{25}$ de los candidatos (a pesar de estar prohibido por la Ley Electoral), que en algunos casos se presentaban a la reelección del cargo que ya ostentaban ${ }^{26}$.

Según la investigación realizada durante las elecciones autonómicas en la Comunidad Valenciana y las generales de 2011, el tratamiento informativo que Canal 9 (RTVV) y La 1 (RTVE) dieron a los

\footnotetext{
${ }^{24}$ En junio de 2011, el Partido Popular, con el presidente Camps reelegido, la nombró consejera de Turismo, Cultura y Deporte de la Generalitat Valenciana y portavoz del Consejo gobernado por el PPCV. El 20 de diciembre de 2011, ya con Fabra como presidente, Johnson fue nombrada secretaria ejecutiva de coordinación de las Comisiones de estudio del Partido Popular de la Comunidad Valenciana, cargo de nueva creación en el partido.

${ }^{25}$ Inauguraciones de infraestructuras públicas.

${ }^{26}$ Entrevista realizada en 2011 a un profesional de RTVV, que deseaba mantener su anonimato por la sombra del ERE que ya planeaba sobre la televisión valenciana.
} 
comicios, distaba mucho del ideal de pluralismo político que los ciudadanos esperamos de una televisión pública.

En la tesis doctoral Pluralismo politico en los programas informativos de Canal 9 y La 1 (TVE) durante las elecciones autonómicas y generales de 2011 se concluye que, si tenemos como referente la línea editorial de la televisión pública BBC, La 1 debía mejorar para alcanzar los niveles de independencia y pluralismo del ente británico, aunque se acerca más a dichos estándares que la televisión pública valenciana.

Gracias tanto a las técnicas cuantitativas como cualitativas utilizadas en la investigación, se concluyó que TVE tenía un grado de independencia mayor durante el periodo de análisis que en etapas anteriores, como en el mandato José $\mathrm{M}^{\mathrm{a}}$ Aznar (1996-2004) con Alfredo Urdaci como director de Informativos.

No obstante, todavía dista mucho del nivel de independencia de la británica (BBC). Hechos como el intento de control del sistema de redacción de noticias en TVE (enews), por parte del Consejo de Administración fueron prueba de ello, pues esto no ocurriría bajo ningún concepto en la BBC. Para la ex editora del Telediario 1, Pepa Rodríguez, "con la Ley 17/2006, cuando se creó el Consejo de Administración, se desperdició la oportunidad de hacerlo estrictamente profesional, porque el actual responde mucho a las cuotas de poder político".

Para empezar, los mecanismos de protección de los profesionales con los que cuentan en la BBC, como el 'Trust', están establecidos desde hace mucho tiempo y su funcionamiento está garantizado por Ley, cumpliéndose escrupulosamente sus funciones. El 'Trust' se creó en 2007, sustituyendo a la anterior Junta de Gobernadores (creada en 1927), sus funciones son controlar al Consejo Ejecutivo en la prestación de servicios de la BBC y nombrar al presidente. Así como la Junta de Gobernadores en el pasado, el 'Trust' es independiente del Consejo Ejecutivo, siendo responsable ante la audiencia y el Parlamento británico de las acciones del ente público.

En cambio, en La 1 el Consejo de Informativos se creó gracias a la aprobación del primer Estatuto de Información de RTVE el 18 de abril de 2008, bajo el amparo de la Ley 17/2006. Como han declarado 
todos los expertos entrevistados para esta investigación, era una vieja reivindicación de los profesionales y fue fundamental el apoyo de la dirección de informativos, dirigida por Fran Llorente (2004-2011). Todos los trabajadores se sentían orgullosos de su existencia y deseaban que el Consejo siguiera adelante al margen del color del partido de Gobierno y de la dirección de turno en RTVE.

Como afirma la ex presidenta del Consejo de Informativos de TVE, Yolanda Sobero, "el Estatuto de Información marca un antes y un después en algo tan importante en nuestra profesión como la autorregulación, que nos sirve tanto para defender a los profesionales como para realizar críticas internas sobre lo que hacemos mal".

Pero TVE es todavía muy joven y no es comparable con la BBC. En RTVE se está empezando el camino, no se han conseguido los mecanismos ni las herramientas con las que cuenta el ente británico, que va muy por delante de la televisión pública española, por la raíz de sus principios constituyentes y, como es lógico, por su larga trayectoria. Para la periodista Ana Pastor, "nos falta dignidad, la BBC ha dado muchas veces un golpe en la mesa frente a la política y cuando invitaban a un político a un debate y ponía condiciones dejaban la silla vacía". En la corporación pública española siguen existiendo muchas presiones políticas y la conexión directa del Congreso de los Diputados con el Consejo de Administración de RTVE, limita mucho la capacidad de actuación de los periodistas.

Por otro lado, en la investigación se concluyó que el nivel de pluralismo de las televisiones públicas está condicionado por el poder político, por tanto, es preciso crear un órgano de control de los medios de comunicación públicos, que sea independiente del Ejecutivo.

Con respecto al tratamiento que Canal 9 dio a los partidos durante la precampaña $^{27}$ se observó como el discurso informativo fue el más utilizado, a pesar de que también existían referencias positivas hacia el PPCV y negativas para el PSPV. También ocurrió durante la campaña electoral, donde continuó el sesgo negativo con el PSPV y positivo con el PPCV.

${ }^{27}$ Periodo no regulado por la Ley Electoral. 
De la misma manera, en el caso de La 1, el tratamiento informativo fue el más utilizado en precampaña, en cambio, se apreció un claro discurso negativo hacia el PP y el PSOE, aunque en menor medida. En este caso las diferencias entre ambos partidos fueron menores que en Canal 9, donde el tratamiento informativo fue el predominante y hubo informaciones positivas y negativas hacia otros partidos de forma más uniforme. Ahora bien, como apuntó el propio abogado de la Junta Electoral de la Comunidad Valenciana, Juan Antonio Martínez Corral: "la proporcionalidad no puede ser matemática". Mientras que en el caso de Canal 9, hubo informaciones negativas de PSPV, EUPV y Compromís, pero ninguna del PPCV. Partido que recibió mayoritariamente referencias positivas por parte de la televisión autonómica valenciana.

Este asunto vuelve a abrir el debate sobre la necesidad de control legislativo para garantizar el pluralismo y la neutralidad informativa. Asimismo, deberíamos cuestionarnos si la normativa actual es suficiente para velar por una buena información durante la campaña electoral, sobre todo en los medios de titularidad pública.

El endurecimiento de la Ley Electoral o su concreción parece que no gusta a nadie, pues iría en contra de la demanda de los profesionales de poder distribuir el tiempo exclusivamente bajo criterios noticiosos y no por cuotas políticas.

De este modo, existe la necesidad de crear un órgano de control independiente del Consejo de Administración de los medios públicos, pues ¿quién sino puede vigilar el cumplimiento de estos valores sin ser parte del proceso informativo? Que haya políticos en el Consejo no es negativo de por sí, pues "el Parlamento representa la decisión de los españoles, por tanto, que en el Consejo estén presentes los representantes de la soberanía popular, a mí no me parece mal", afirma la periodista Pepa Bueno. Sin embargo, resulta necesario un organismo que pueda supervisar la actuación de los políticos y que vele por la audiencia y los trabajadores del medio, como ocurre en la BBC. 
Actualmente el presidente de RTVE es elegido por el Parlamento, ahora bien, el cambio de legislación que promulgó $\mathrm{Rajoy}^{28}$ y que posibilita la elección en segunda vuelta por mayoría simple, ha limitado la necesidad de consenso entre las distintas fuerzas políticas. Así la elección del presidente de la Corporación pública queda a merced del partido en el poder y la independencia del ente respecto al Gobierno se reduce todavía más. Igualmente ocurría en RTVV, cuyo presidente se elegía directamente por el presidente de la Generalitat Valenciana. Si bien, con la creación del nuevo Estatuto de RTVV antes de su cierre, se adoptó el mismo sistema impuesto en RTVE con la nueva legislación del PP.

De modo que, debería haber una división de poderes más clara en las televisiones públicas españolas, ya sea con un órgano interno (autorregulación) o con un Consejo Audiovisual Nacional (regulación), que podría controlar todo el espectro radiotelevisivo (público y privado) en España.

En cambio, hay algunos profesionales que tienen reservas sobre la creación de un órgano más, que pueda volver a ser instrumentalizado por los políticos y desean una institución totalmente profesional. Desde el Consejo de Informativos de TVE apuestan por la creación del Consejo Audiovisual Nacional "que regule la situación, pero es clave que tenga competencia sancionadora para que sirva para algo". Además, denuncian el desinterés de todos los partidos políticos que han gobernado el país, que prometieron su creación y que han ido posponiéndolo hasta el día de hoy.

Otra de las conclusiones que se extraen de la investigación es la confirmación de que tanto La 1 como Canal 9, cumplieron con la legislación electoral y respetaron los tiempos determinados por la misma en campaña. Por lo que la Ley Electoral se plantea como un elemento indispensable para garantizar un mínimo de pluralismo, pues los resultados de la semana precampaña mostraron una menor pluralidad. En las ilustraciones 4, 5 y 6 se aprecia la proporcionalidad que requiere la LOREG a la hora de repartir el tiempo, para que cada

\footnotetext{
${ }^{28}$ Real Decreto Ley 15/2012, de 20 de abril, de modificación del régimen de administración de la Corporación RTVE, previsto en la Ley 17/2006, de 5 de junio.
} 
partido político lance sus consignas y publicidad electoral durante la campaña.

En los análisis de contenido se concluyó que, los dos entes públicos tuvieron en cuenta el conjunto de la campaña electoral para cumplir con dicha proporcionalidad, pues como advertía el ex director de Programación y Gestión de Informativos de TVE, Xavier Obach, si midieran el tiempo por programas "nos encontraríamos con situaciones kafkianas y habría partidos que aparecerían un segundo". Asimismo, hay que matizar que, por ese mismo motivo, la LOREG no establece una proporcionalidad matemática.

Además de los resultados obtenidos en esta investigación, hay que resaltar que las denuncias que se produjeron sobre los planes de cobertura no fueron admitidas por las respectivas Juntas Electorales, por lo que el cumplimiento de la Ley fue indiscutible.

Asimismo, queda demostrado que en Canal 9 hubo cierta propensión por el partido que ostentaba el poder. RTVV era una corporación pública progubernamental.

En Canal 9 se constató como en la última semana de precampaña, antes de las elecciones autonómicas de 2011, existía una clara preferencia informativa hacia el Partido Popular de la Comunidad Valenciana (PPCV) y de su líder y presidente de la Generalitat, Francisco Camps. En el tratamiento audiovisual que realizó Canal 9 a los candidatos en el periodo no regulado por Ley, observamos que no utilizaba los planos favorables o desfavorables, para no ensalzar o denostar la imagen de ninguno en particular. No obstante, en campaña, Canal 9 manejaba los planos favorables tanto con el candidato del PPCV, como del PSPV, con una leve mayoría para Francisco Camps, en aquel momento presidente de la Generalitat Valenciana.

En cuanto a los comentarios de los presentadores de los programas informativos y los periodistas invitados como tertulianos, se apreciaba una clara predilección hacia el PPCV y Camps, ya que el 95,9\% de los comentarios positivos se referían a ellos y nunca tuvieron una opinión negativa al respecto durante la precampaña. Por el contrario, al principal partido de la oposición, Partido Socialista del País 
Valenciano y a su líder Jorge Alarte, les dedicaron el 87,7\% del total de comentarios negativos que realizó la cadena autonómica.

En el periodo de precampaña, libre de legislación, quedó patente que la televisión pública valenciana estaba totalmente condicionada por el partido que gobernaba entonces (PPCV), al que claramente favorecía cuando no había un control sobre el contenido informativo del medio. De hecho, según profesionales consultados en la investigación, "fuera de campaña, en ocasiones, se han recibido órdenes desde la dirección de que no aparezcan imágenes de Eduardo Zaplana ${ }^{29}$ o de José Joaquín Ripoll’"30, puesto que ambos fueron voces críticas dentro del Partido Popular valenciano, formando una facción interna contraria a Francisco Camps. Episodios como los ocurridos en plena campaña electoral cuando, durante el debate entre candidatos $^{31}$, se situó deliberadamente un rótulo delante de Mónica Oltra (Compromís) tratando de ocultar su camiseta de denuncia contra Canal 9; las órdenes de no decir la palabra indignados porque en la Comunidad Valenciana todo iba bien; o no hablar del Caso Gürtel $^{32}$ hasta que no hubo más remedio, etc. Estas prácticas denotaban una intencionalidad, a la hora de ocultar la información que no era favorable a los intereses de la directiva de RTVV o del PPCV, que gobernaba la Generalitat.

Las declaraciones de fuentes consultadas para esta investigación doctoral, apoyaban los resultados de la misma con experiencias personales que demuestran el control que ejercía la dirección de RTVV sobre sus trabajadores. Entre las más reveladoras se encuentran las afirmaciones del ex presidente del Comité de Empresa de RTVV, Vicent Mifsud, quien aseguró que "lo que hay es una pauta

\footnotetext{
${ }^{29}$ Presidente de la Generalitat Valenciana por el PPCV desde 1995 hasta el 2002.

${ }^{30}$ Presidente del PPCV de la provincia de Alicante entre 2004 y 2011.

${ }^{31}$ Debate emitido en Canal 9 el 18 mayo de 2011

${ }^{32}$ Fuera del periodo de esta investigación, la representante del PSPV, Cristina Moreno, realizó una queja el 6 de abril ante la JECV porque en el informativo NT9 $1^{\circ}$ edición, informaron durante casi 3 'del comienzo del juicio del socialista valenciano, Ángel Luna, pero no mencionaron nada sobre la noticia que circulaba durante ese día de la audiencia preliminar sobre los trajes de Camps, ni apareció en ningún medio de RTVV.
} 
de cobertura que marca la dirección, la estructura está montada para que llegue a través de peldaños, pero nunca se podrá probar que las órdenes llegan de ningún partido". Por eso, entre otros motivos, Mifsud explicaba que la dirección utilizaba el 3\% de contratación libre para situar a personas muy afines ideológicamente. Como por ejemplo al ex-jefe de prensa de Esteban González Pons ${ }^{33}$ (PP), que fue contratado para cubrir la información electoral de Jorge Alarte, candidato del PSPV; o las condiciones privilegiadas que tenía Isabel Durán, presentadora en ese momento del programa de Canal 9 'DBT', quien cobraba 3.000 euros por programa y además, se le facilitaban las instalaciones públicas de RTVV para realizar su programa de radio 'La espuela' de Intereconomía. Este programa, remarcaba Mifsud, era el principal competidor de Radio 9 en esta franja horaria. Simplemente los salarios de la presentadora y los tertulianos del programa, suponían un coste semanal de 8.820 euros a todos los valencianos.

El secretario de Comunicación de EUPV, Ignaci Blanco, alertaba de que la "manipulación es diaria y evidente, desde no informar sobre el caso Gürtel hasta estigmatizar cualquier manifestación pública contra el PPCV'. Finalmente ponía como ejemplo el programa 'DBT' en el que "todos los comentaristas son de extrema derecha y secundan una línea argumental propia de las cadenas más ultra". Blanco fue tajante al afirmar que "no hacen falta pruebas de que no hay pluralismo en Canal 9, es una evidencia tan grande como que el sol sale cada mañana". También el entonces responsable de Comunicación de Compromís, Enric Cuenca, explicaba como 'Info-tv' ${ }^{34}$ emitió un video en el que "se podía ver a la jefa de prensa de Camps, Nuria Romeral, dando instrucciones a una reportera de Canal 9 sobre cómo enfocar la noticia".

En definitiva, según Mifsud los favores en RTVV se hacían con frecuencia, sin ir más lejos el directivo Pedro García fue el responsable de firmar los contratos del ente público para la visita del

\footnotetext{
${ }^{33}$ En el momento de la investigación Vicesecretario general de Comunicación del PP.

${ }^{34}$ Es la marca comercial de Infovalència Televisió, SA, una empresa creada el 2004 y que tenía como objetivo principal poner en marcha un canal de televisión independiente, profesional, plural y en valenciano.
} 
Papa, constituyendo según investigaciones policiales, una empresa paralela a la que desvió 500.000 euros. "Entre Correa, Pablo Crespo, Pedro García y Álvaro Pérez robaron el salario de 400 trabajadores en un año", concluye el presidente del Comité de Empresa de RTVV refiriéndose a la trama Gürtel.

Otra de las conclusiones a las que se llegó en la investigación fue que la legislación electoral era la única garantía de visibilidad para los líderes de la oposición en la Comunidad Valenciana. Gracias a la Ley 1/1987 Electoral Valenciana y a L.O. 5/1985 Régimen Electoral General, que obligan a las televisiones públicas a garantizar la proporcionalidad y la neutralidad durante el periodo de campaña electoral, se advirtió una clara diferencia en cuanto a la visibilidad de los partidos de la oposición, entre el periodo legislado y no legislado, aumentando su aparición en Canal 9 cuando así lo dictaba la Ley.

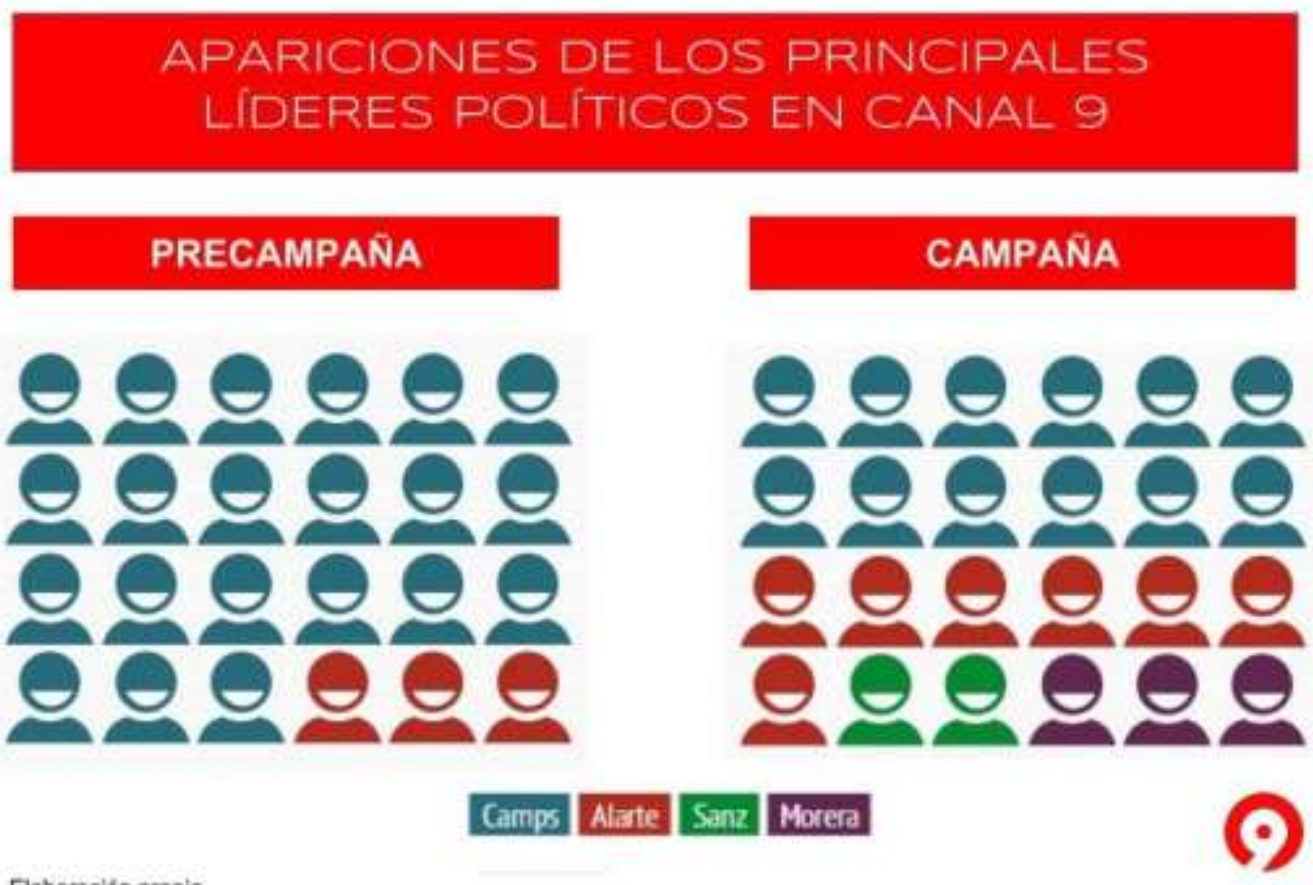

Elaboración propia

Datos Tesis doctoral (Lopez. 2012) Elecciones autonómicas Comunidad Valenciana 2011

Ilustración 4. Visibilidad de los líderes en los programas informativos de Canal 9 durante las elecciones autonómicas de 2011.

Podemos apreciar como en Canal 9 la visibilidad del líder del PPCV, Francisco Camps, era superior al resto de líderes en precampaña. Así pues, vemos como del total de declaraciones de todos los líderes políticos, Camps ocupaba el 86\% del tiempo analizado, Alarte (PSPV) 
el 14\% y Sanz (EUPV) y Morera (Compromís) ni si quiera aparecían haciendo declaraciones en Canal 9 durante la última semana de precampaña. Mientras en campaña electoral, se observó como en Canal 9 los líderes del resto de partidos aparecieron haciendo declaraciones de manera proporcional y el discurso de Camps no acaparó el tiempo en pantalla de forma tan drástica.

Otro ejemplo de cómo evolucionó el tratamiento informativo en Canal 9 quedó patente en los rótulos que aparecían en los programas informativos. Hay que destacar que en precampaña, Canal 9 utilizó los rótulos informativos mayoritariamente, seguido de los sensacionalistas y los opinativos. Sin embargo, durante la campaña, el canal público valenciano amplió considerablemente el número de rótulos informativos, en detrimento del resto de rótulos subjetivos, que suponían únicamente un 1,6\% del total.

Como explicó el ex jefe de Gabinete de Alarte (PSPV), Josep Moreno, "a lo largo de la legislatura, desde que fue elegido nuestro candidato Jorge Alarte, sólo ha aparecido en Canal 9 durante 15 minutos en una entrevista del programa 'Bon Día Comunidad Valenciana' presentado por Xavier Carrau". Y para el resto de formaciones tampoco era fácil. Del mismo modo, el secretario de Comunicación de EUPV, Ignaci Blanco, afirmó: "nosotros comunicamos lo que hacemos a todos los medios con ruedas de prensa, etc. y alguna vez viene algún redactor o cámara de Canal 9". Algo de lo que también protestaban en Compromís pues: "es incomprensible que no cubran casi nada con una plantilla sobredimensionada y lo peor son las excusas, que son de risa", afirmaba Enric Cuenca.

En definitiva, la legislación era el principio que permitía, que los líderes de la oposición de partidos minoritarios pudieran realizar declaraciones en la televisión pública valenciana.

Además, la tesis evidencia que La 1 de TVE y Canal 9 dieron más visibilidad a los dos partidos mayoritarios en el periodo no legislado, favoreciendo el bipartidismo y relegando al resto de partidos a una aparición en pantalla mínima. 
Los resultados obtenidos en esta investigación sobre Canal 9, desvelaron claramente una mayor presencia del partido de gobierno (PPCV) y de su candidato sobre los demás.

Durante la precampaña el PPCV apareció tanto como partido, como a través de la propia información institucional de la Generalitat, abarcando un total el 79\% del tiempo de información política. Por otro lado, el PSPV acumuló el 19\% del total y EUPV y Compromís se visibilizaron un $1 \%$ cada uno.

Esta circunstancia fue diferente en el periodo de campaña, puesto que la Ley exige la presencia de los partidos con representación parlamentaria y la visibilidad de EUPV y Compromís aumentó considerablemente del $1 \%$ al $11,32 \%$ y el $10,71 \%$ respectivamente. En cuanto al PPCV apareció el 46,77\%, incluida la información institucional de la Generalitat y el PSPV el 30,62\% del total de la información política en campaña. En resumen, se observó una mayor proporcionalidad entre todos los partidos.

En consecuencia, se demostró que Canal 9 tenía una fuerte dependencia del poder y que, sin la obligación legal de dar cabida a los partidos de la oposición, hubiese sido mucho menos plural en el periodo de campaña electoral.

Fuera del periodo legislado, se escudaba en el criterio profesional, un aspecto muy subjetivo, para justificar la ausencia del resto de partidos que no estaban en el Gobierno. Ejemplo de ello fue el silencio informativo de la manifestación multitudinaria contra la corrupción, que se celebró el 26 de marzo de 20011 en Valencia, y que siguiendo los criterios de la dirección de RTVV no era información de interés. Aunque claramente respondía más a intereses políticos, porque perjudicaba la imagen del Gobierno de la Generalitat. En definitiva, según fuentes consultadas" " "los casos puntuales como la corrupción o cualquier cosa que afectaba al PSPV se magnificaba de manera descomunal, y lo que afectaba al PPCV al revés, o no se daba, o se daba de manera muy liviana."

\footnotetext{
${ }^{35}$ Algunos trabajadores de RTVV entrevistados durante la investigación quisieron mantenerse en el anonimato.
} 
A pesar de que La 1 de TVE informaba sobre otros partidos en la última semana de precampaña, su visibilidad con respecto a PP y PSOE fue mínima.

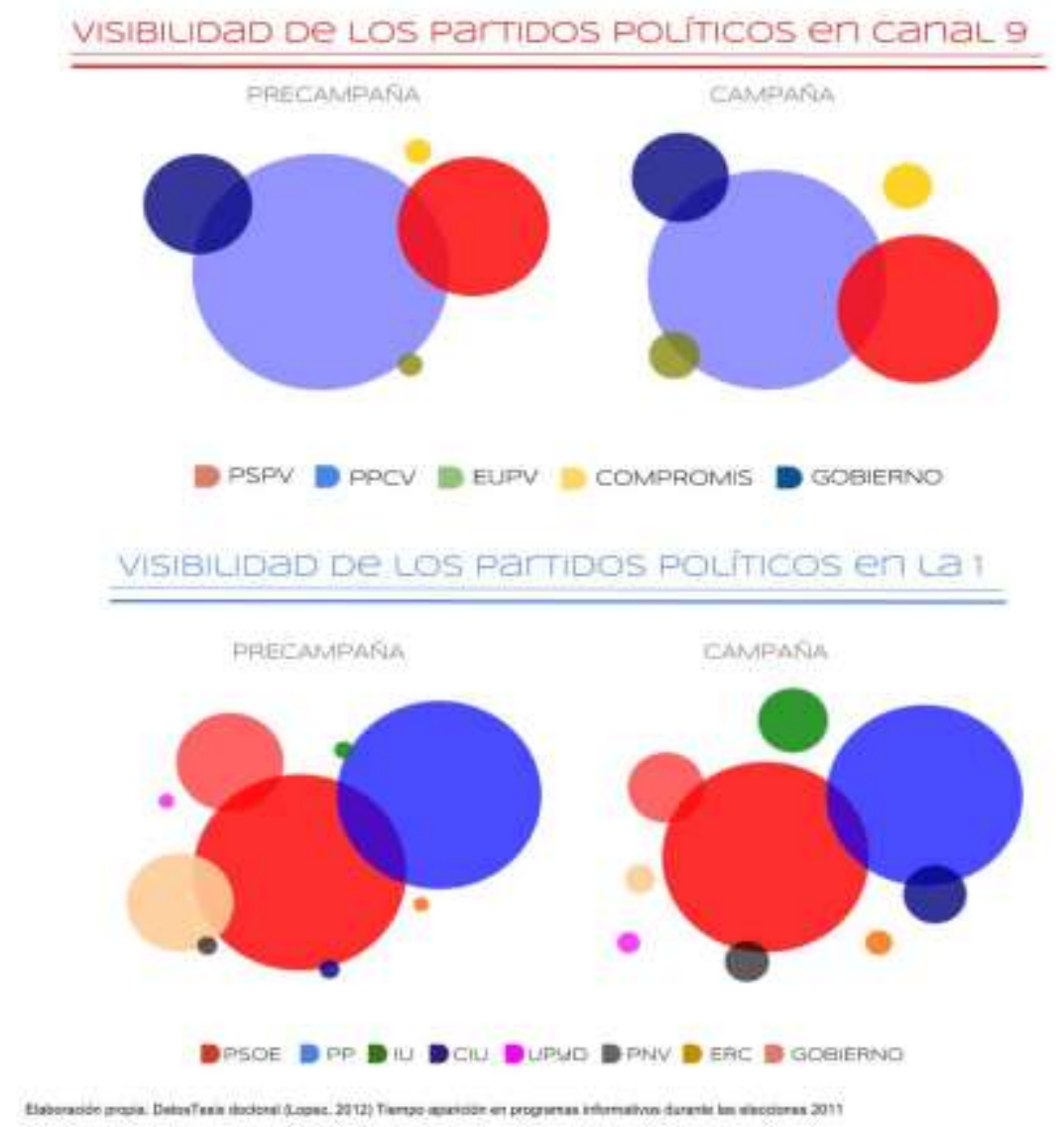

Ilustración 5. Tiempo de aparición de los partidos en los programas informativos de Canal 9 y La 1 durante las elecciones autonómicas y generales de 2011.

Cabe destacar, que durante la última semana de precampaña el PP $(34,09 \%)$ aparecía más que el PSOE (31,84\%), partido en el Gobierno en el periodo de la investigación, mostrándose la intención del ente en ese momento de ser plural y no gubernamental. Sin embargo, vemos que el resto de partidos no tuvieron apenas cabida cuando no había regulación. Los pesos de sus apariciones fueron: IU el 1,22\%; CIU 1,64\%; PNV el 1,60\%; ERC el 0,75\%; UPYD un $0,50 \%$; BNG el 0,04\%; ICV-EUIA 0,29\%; EQUO un 0,19\% y UPN $(14,12 \%)^{36}$.

\footnotetext{
${ }^{36}$ Caso que estuvo sujeto a la actualidad por el incidente que sufrió Yolanda Barcina, presidenta de Navarra, que fue entrevistada en 'Los Desayunos' el 31 de octubre de 2011.
} 
En cambio, durante la campaña la proporcionalidad en la cadena pública estatal aumentó y los partidos con menos presencia fuera del periodo regulado, cobraron más protagonismo, quedando repartido el tiempo de información política de esta manera: PSOE 33,95\%; PP 30,02\%; IU 7,73\%; CIU 7,20\%; PNV 5,27\%; ERC 2,53\%; UPyD 2,90\%; BNG 1,84\%; CC 1,66\%; GBAI 0,05\%; Amaiur 0,05\%; PRC 0,03\%; ICV-EUIA 0,02\%; EQUO 0,04\% y FAC 0,05\%.

Igualmente, fueron más visibles los líderes de los partidos mayoritarios (Alfredo P. Rubalcaba y Mariano Rajoy), aunque al contrario que en Canal 9, sí hubo cabida para los candidatos del resto de formaciones políticas durante la precampaña.

Cabe destacar el repunte en campaña de Josu Erkoreka del PNV, pues su presencia en el 'Debate a cinco' de La 1 le proporcionó más minutos como candidato, puesto que a ese debate acudieron representantes del PSOE, PP, IU, y CIU que no eran los propios líderes de partido.

\section{APARICIONES DE LOS PRINCIPALES LÍDERES POLITICOS EN LA 1}

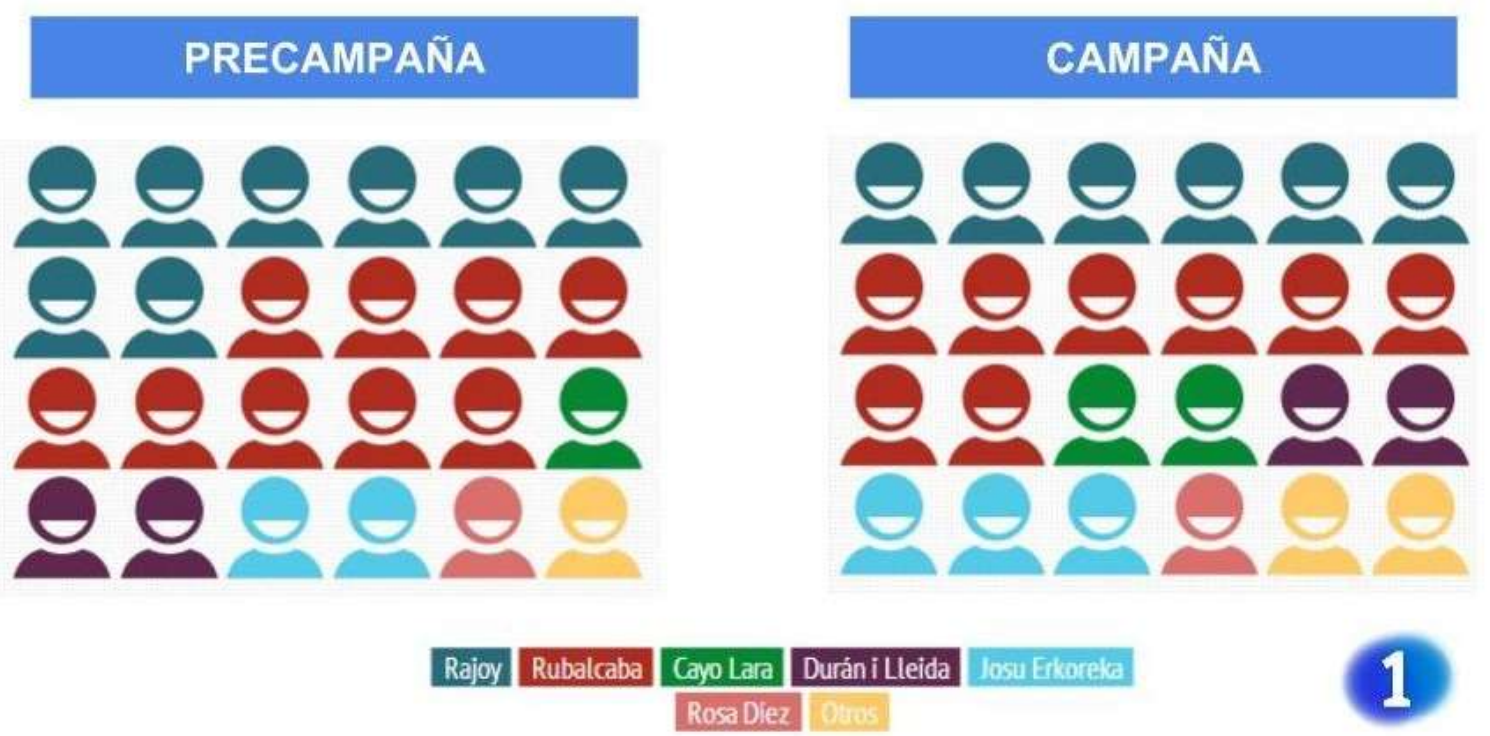

Elaboración propia

Datos Tesis doctoral (Lopez, 2012) Elecciones Generales 2011

Ilustración 6. Visibilidad de los líderes en los programas informativos de La 1 durante las elecciones generales de 2011. 
Ahora bien, en el total de tiempo de aparición de campaña, el PNV apareció de forma proporcional a los resultados obtenidos en las elecciones generales del 2008, como el resto de formaciones.

Aunque la diferencia entre los partidos mayoritarios y minoritarios fue mayor en Canal 9, las dos televisiones públicas analizadas, otorgaron mayor visibilidad a los principales partidos políticos cuando no había legislación.

En otro orden de cosas, el estudio constató que existe una demanda por parte de los profesionales de la información, para que se reparta el tiempo electoral entre los partidos bajo criterios noticiosos y no legales como hasta ahora.

Estas diferencias nos llevan a plantearnos si la regulación de los tiempos de cada partido debe venir marcada por la LOREG, basándose en la proporcionalidad de la representación parlamentaria de cada formación política en los comicios anteriores o si, por el contrario, debe ajustarse a criterios noticiosos como reclaman algunos profesionales del periodismo.

El debate está abierto, pero si nos apoyamos en los datos obtenidos en esta investigación, la Ley Electoral es una garantía más para que los medios de comunicación, públicos y privados, respeten unos mínimos en cuanto al pluralismo político. Fuera de los periodos electorales en los que no hay regulación, queda patente que el pluralismo está a merced de la profesionalidad y el buen hacer de la dirección del medio, que a veces defiende más los intereses políticos o económicos que los del público.

Sin embargo, desde el Consejo de Informativos de TVE apoyan a los trabajadores del ente, que apuestan en su mayoría por desregularizar la campaña electoral y permitir a los profesionales gestionar el tiempo que se dedica a los partidos en función de su interés periodístico, porque a pesar de que los partidos mayoritarios "tengan más votos no significa que generan más noticias", afirma su ex presidenta, Yolanda Sobero. 
De hecho, al comienzo del bloque electoral en los Telediarios, los presentadores advertían que: "La información electoral se la contamos en el orden y la proporción de tiempo que marca la JEC en función de los votos que consiguieron los partidos en las últimas elecciones. Algo que no comparte el Consejo de Informativos de TVE, que defiende el criterio estrictamente profesional".

No obstante, durante la investigación se concluyó que La 1 fue más plural y neutral que Canal 9. A pesar de que ambas televisiones públicas debían mejorar en cuanto a los niveles de independencia y pluralismo político, se apreció claramente que la televisión nacional era más plural y neutral que la autonómica en el momento de este análisis.

Entre otros factores, en los resultados de este estudio se ha observado la variedad de partidos políticos que tuvieron cabida en la cobertura informativa de las elecciones generales y autonómicas en cada televisión. Mientras La 1 de TVE incluyó, aunque brevemente, información de partidos que ni siquiera tenían representación parlamentaria (EQUO, Amaiur, FAC, etc.) sin romper con la proporcionalidad que exige la Ley Electoral, Canal 9 sólo se limitó a dar visibilidad a los partidos con representación en Les Corts valencianas, incluso dejó patente la ausencia de los candidatos de EUPV y Compromìs durante la precampaña, donde no hay legislación.

Incluso en la rotulación de las informaciones de La 1 se observó una gran diferencia con Canal 9, pues todos los rótulos de la televisión nacional fueron informativos tanto en precampaña como en campaña, mientras en la televisión valenciana se abusó de los opinativos y sensacionalistas en precampaña, lo que denota una clara diferencia entre las prácticas de ambos canales públicos en este sentido.

Cabe destacar el uso normalizado en La 1 de imágenes realizadas por los propios partidos, que seleccionaban contenidos y planos favorables de sus candidatos. Es reprochable el abuso de imágenes editadas por las formaciones políticas, aunque siempre las señalizó como tal. Sin embargo, hay que remarcar que en Canal 9 el uso de señal realizada por los partidos era menor, por lo que la 
intencionalidad a la hora de la realización de las imágenes fue responsabilidad de la cadena pública autonómica.

Otro elemento importante en el grado de independencia y pluralismo, son las herramientas con las que contaba cada una de las televisiones públicas analizadas. La 1 tenía su reciente, pero eficaz, Consejo de Informativos, con el que todos los profesionales decían sentirse satisfechos, amparados y vigilados cuando se equivocan, ayudándoles a mejorar.

Por el contrario, Canal 9 contó con un Consejo de Redacción que desapareció después de desempeñar su papel propagandístico para el PPCV, afirmaba el expresidente del Comité de Empresa de RTVV, Vicent Mifsud. En el momento de la investigación, este organismo no estaba en funcionamiento, puesto que ningún trabajador quería formar parte del mismo por las presiones de la empresa, lo que indica una diferencia abismal en el ambiente de trabajo, la independencia profesional entre ambas cadenas públicas y en todo lo referente a las relaciones laborales.

Sobre la evolución o involución del concepto de pluralismo en ambas cadenas, los responsables de comunicación de los partidos se mostraron muy críticos: Para la entonces responsable de Comunicación de Geroa Bai, Nerea Martínez, "hay pluralismo en TVE, aunque siempre se puede pedir más". Igualmente, el responsable de Comunicación de IU, Armando Recio, trasladaba en ese momento el sentir de su partido, donde pensaban que: "hay un pluralismo razonable y que la televisión pública ha evolucionado y mejorado desde 2004 hasta hoy. Esperamos que siga siéndolo y que no se vuelva a la etapa de Aznar ${ }^{37}$ y Urdaci" 38 .

\footnotetext{
${ }^{37}$ José Ma Aznar, presidente del Gobierno (1996-2004) por el Partido Popular.

38 Periodista, director de Informativos de TVE de 2000 a 2004. Sigue recordándose el episodio con CC.OO. que denunció a TVE por haber manipulado las informaciones en favor del gobierno, antes y durante la huelga general del 20 de junio de 2002, en el segundo mandato de José María Aznar como presidente. Urdaci leyó la rectificación tras los créditos y la sintonía del fin del informativo, a una velocidad mayor de la habitual y diciendo el nombre del demandante como "ce, ce, o, o", cuando la lectura de siglas es una práctica inusual en televisión y radio.
} 
Desde el PNV, en aquel momento su responsable de comunicación, Iñaki Bernardo, afirmó que "depende quien controle RTVE hay pluralismo o no, pero no demasiado, aunque con la Ley son más plurales que otros medios", además alegó sentirse satisfecho con el tratamiento que le dio TVE a su partido "fuera de campaña, pero en campaña se ha fomentado el bipartidismo utilizando también los espacios no electorales y fuera de control de la Junta Electoral para conseguirlo". Tampoco estaban satisfechos con el trato recibido en UPYD y así lo dejó patente su entonces responsable de comunicación, Juan de Ávila, quien aseguró que en la televisión pública nacional "hay pluralismo, pero escaso". En este sentido esta investigación analizó los programas informativos con toda la información política en su conjunto, no sólo los bloques electorales, y se puede concluir que la proporcionalidad legal se cumplió.

Por lo que respecta a Canal 9, todos los partidos de la oposición consultados declararon sentirse insatisfechos con el tratamiento que se les dio en Canal 9 durante la campaña y mucho más durante toda la legislatura. Cabe mencionar que el PSPV fue el partido que más denuncias realizó sobre los programas informativos de Canal 9 ante la Junta Electoral de la Comunidad Valenciana, si bien ni sus reclamaciones ni las que efectuó EUPV, Compromís y Coalición Verdes y Ecopacifistas fueron admitidas.

Según Josep Moreno, ex responsable del Gabinete de Alarte (PSPV), Camps llevó a las últimas consecuencias un modelo creado por Berlusconi: "Un partido sin ideología, sin compromisos, que se limita a decirle a la gente lo que quiere oír y una vez llegas al poder completas la perversión del sistema con la televisión pública, devaluándola y desprestigiándola”.

En aquel tiempo el responsable de Comunicación de Compromís, Enric Cuenca, denunció que "la falta de pluralidad en Canal 9 es muy problemática no sólo con los partidos sin representación parlamentaria sino con asociaciones y colectivos ciudadanos que tampoco tienen espacio". De igual forma el secretario de Comunicación de EUPV, Ignaci Blanco, afirmó que en su partido se 
sienten "desplazados en Canal 9 como toda la oposición política y social en el País Valenciano".

Finalmente, al término de la tesis doctoral, quedó manifiesto que la accesibilidad y transparencia de La 1 fue mayor que en Canal 9.

En la investigación se planteó desde el principio la necesidad de contar con todas las voces implicadas. Por lo que respecta a los principales objetos de estudio (Canal 9 y La 1) hubo grandes diferencias en cuanto a la accesibilidad y la transparencia a la hora de facilitar información.

Desde la dirección de RTVV no quisieron participar en ningún sentido en esta investigación, por ello la observación no participante se realizó en Alicante en la jornada electoral y no en Valencia, gracias a la colaboración personal de Ignacio Lara, profesor de la Universidad Miguel Hernández y coordinador de Informativos de Canal 9 Alicante.

En el caso de RTVE la comunicación fue mucho más fluida, desde el primer momento estuvieron abiertos a facilitar el acceso a Torrespaña en Madrid, para poder realizar todo el estudio de observación no participante durante los últimos días de campaña. De la mano del ex director de Programación y Gestión de Informativos, Xavier Obach, se organizaron entrevistas con editores de informativos, presentadores, directores de programas informativos y miembros del Consejo de Informativos.

El ambiente de trabajo en TVE fue muy distendido, las entrevistas se desarrollaron con naturalidad y pude conocer sus instalaciones de Torrespaña con total libertad. Mientras que en Canal 9, la observación se limitó a una pequeña estancia en la redacción de Alicante, y la mayoría del tiempo a ver el trabajo del equipo enviado a la sede del PPCV alicantino mientras se esperaban los resultados electorales.

Al mismo tiempo se observaron diferencias entre los partidos políticos que gobernaban en el momento de la investigación (PPCV en la Comunidad Valenciana y PSOE en el Gobierno central) y la oposición, siendo éstos últimos más colaborativos. 
Hay que señalar negativamente la poca predisposición que manifestaron los partidos que estaban en el poder (tanto a nivel autonómico como nacional) durante esta investigación. Ni el PPCV, ni el PSOE quisieron realizar ninguna declaración al respecto. En cambio, la oposición en la Comunidad Valenciana colaboró en su totalidad (PSPV, EUPV, Compromís), a través de entrevistas personales que se efectuaron en sus oficinas parlamentarias en Les Corts valencianas.

Por otra parte, fue más difícil contactar con los partidos nacionales, pero a pesar de todo, se consiguieron entrevistas a los responsables de comunicación de IU, PNV, UPyD, GBAI y Compromís-Q ${ }^{39}$.

Como declaró la ex editora del Telediario 1, Pepa Rodríguez, "a los políticos en general les interesan las televisiones públicas cuando les sirven para algo" 40 . En definitiva, ante este concepto crítico, los departamentos de comunicación de los partidos de Gobierno han mostrado demasiadas reservas a la hora de responder a los interrogantes planteados en esta investigación.

\footnotetext{
${ }^{39}$ En la Comunidad Valenciana, EQUO se unió a la coalición Compromís para las elecciones, formada por el BLOC, IdPV y EV-EE. En las Elecciones Generales de 2011 consiguieron un diputado, Joan Baldoví.

${ }^{40}$ Siguiendo la misma línea de Iñaki Gabilondo, en el programa de La Sexta 'Salvados' del 04-11-2012, en el que declaró que "en las autonomías cuando ganabas las elecciones te daban una televisión y una caja de ahorros".
} 



\section{La deriva de las televisiones públicas en España}

\section{Del modelo BBC de Fran Lorente en RTVE a los ERES, el telepartidismo y las privatizaciones}

— $\mathrm{N}$ contraposición a nuestro modelo de televisión pública independencia con el poder político y adalid de la ética periodística.

En 1922 el Gobierno británico creó la British Broadcasting Corporation, un conglomerado de seis empresas radioeléctricas que comenzaron a emitir a través de la radio con el beneplácito de la Corona. El rey Jorge V realizó el primer mensaje de Navidad y cuatro años después (1926) les concedió la Carta Real (Royal Charter), la Carta de Constitución que la convertía en empresa pública. Esta carta se renueva cada diez años por el propio Rey, la última fue otorgada por la Reina Isabel II de Inglaterra en 2006.

Las emisiones de televisión comenzaron en 1936, como instrumento para controlar la información desde el Gobierno británico. John Reith fue el primer director general de la corporación británica y de sus valores escoceses y presbiterianos han quedado las máximas de la BBC: informar, educar, y entretener. Igualmente se mantiene su promesa de imparcialidad en política, noticias y asuntos de actualidad. Para asegurar la imparcialidad, la BBC nació con la prohibición de tratar temas controvertidos y a pesar de que el Gobierno eliminó esa 
norma en 1928, ha seguido siendo un principio básico para el ente estatal.

Los fines públicos establecidos en la Carta Real son la base de la constitución de la Corporación británica cuya misión es "enriquecer la vida de las personas con los programas y servicios de informar, educar y entretener". Su visión es "ser la organización más creativa del mundo", por ello sus valores son:

"La confianza es la base de la BBC: somos independientes, imparciales y honestos; las audiencias están en el corazón de todo lo que hacemos; estamos orgullosos de ofrecer calidad y valor por lo que paga la audiencia; la creatividad es el elemento vital de nuestra organización; nos respetamos y celebramos nuestra diversidad para que todos puedan dar lo mejor de sí; somos uno porque las grandes cosas suceden cuando trabajamos juntos" ${ }^{\prime 4}$.

Su financiación depende de un canon impuesto por el Gobierno, regulado en el artículo 364 de la Ley de Comunicación de 2003, según el cual todo ciudadano que quiera ver la BBC, tanto por Internet como a través de la televisión, debe pagar. Los precios varían y existen descuentos para receptores en blanco y negro, y personas con minusvalía. Además, parte de su presupuesto proviene de la venta de las producciones propias a medios de todo el Mundo.

Su estructura empresarial está encabezada por el Chairman (presidente de la Corporación). La gestión se divide en dos organismos fundamentalmente: la BBC 'Trust' (Consejo de Confianza) y el Consejo Ejecutivo. El primero se ocupa de hacer cumplir la Carta Real y los principios de servicio público, así como ser garante del canon. Su personal es independiente del Consejo Ejecutivo y no actúa nunca en su nombre. Está formado por un presidente, un vicepresidente y diez comisarios entre los que hay un representante de cada una de las naciones del Reino Unido ${ }^{42}$. El segundo, tiene responsabilidad operativa y se encarga del funcionamiento del medio de comunicación. Del Consejo Ejecutivo

${ }^{41}$ Inside the BBC www.bbc.co.uk
${ }^{42}$ Irlanda del Norte, Gales, Escocia e Inglaterra. 
emana la figura del director general de la $\mathrm{BBC}$, que es el responsable de la línea editorial y del control de la actividad profesional del ente.

Otro organismo fundamental para garantizar los valores de la BBC es el Audience Council (Consejo de Audiencia), que garantiza la diversidad de todas las naciones británicas en la corporación, para ello hay representantes de cada una de las cuatro naciones; aconseja y asesora al 'Trust' sobre el cumplimiento de las funciones de la BBC para satisfacer las necesidades de sus abonados, para lo cual presenta un informe anual y atiende consultas y reclamaciones de la audiencia.

Tanto el 'Trust' como el Consejo Ejecutivo son los responsables de solucionar incidencias con los profesionales de la casa y de presentar las cuentas anuales del ente público, a las cuales tiene acceso el Secretario de Estado, el Secretario de Relaciones Exteriores y cualquier persona designada para tales fines.

Por su parte, la historia de RTVE es muy distinta, pues nace bajo un Gobierno dictatorial que duró 40 años y dejo a España aislada del Mundo en muchos sentidos.

El 28 de octubre de 1956 comenzaron oficialmente las emisiones regulares en España. A las 20:30 horas, el primer programa consistió en la retrasmisión de una misa, unos discursos oficiales, la exhibición de dos entregas del NO-DO, unos reportajes filmados y las actuaciones de unas orquestas y de los Coros y Danzas falangistas. Las emisiones se producían desde el Paseo de la Habana en Madrid, donde disponían de un minúsculo plató de unos cien metros cuadrados. Durante casi tres años TVE fue una televisión local con ámbito de cobertura exclusivamente en la ciudad de Madrid.

Dos años después, en febrero de 1959, se estrenaba el servicio en las ciudades de Barcelona y Zaragoza, agotando todos los televisores que estaban a la venta en la Ciudad Condal. Esta expectación se repetía en todos los lugares a los que iba llegando la televisión.

Si bien se tardaron varios años hasta que la gran mayoría de los españoles tuvieron acceso al servicio. La televisión llegó a Castilla La Mancha y Castilla y León a través del repetidor de la sierra de Guadarrama, en octubre de 1959; a Valencia en febrero de 1960; a 
Bilbao en diciembre de 1960; a Galicia y Sevilla en octubre de 1961 y, dando por completada la red, en Canarias en febrero de 1964.

Cuando los españoles hicieron de la televisión su principal forma de ocio, TVE experimentaba su época dorada. Sin problemas financieros significativos y sin competencia, era una máquina de hacer dinero, con capacidad de producción para elaborar programas propios de calidad. Este avance se debió probablemente a que en España, al contrario que en las televisiones públicas europeas, la publicidad televisiva no estaba prohibida o restringida. Esto configuró un modelo de financiación comercial, y los ingresos de TVE se conseguían a partir de la recaudación por los anuncios emitidos. Como consecuencia, y gracias a la total desregulación existente, el ente aumentaba el tiempo de publicidad o las tarifas de anuncios según sus propias necesidades presupuestarias.

El marco jurídico en aquellos primeros años atribuía la gestión del ente a la Dirección General de Radiodifusión y Televisión, dentro del Ministerio de Información y Turismo. El Decreto 2460/1960, del 29 de diciembre es la primera norma que contempla específicamente el nuevo medio.

Puede decirse que este periodo se inicia con la inauguración de los estudios de Prado del Rey en 1964, que acaban con la precariedad técnica de los orígenes. El despegue del ente continúa con la puesta en marcha el 15 de noviembre de 1966, de un segundo canal de TVE (TVE 2), conocida en sus orígenes como UHF, por utilizar para su emisión esta banda de radiofrecuencias. En TVE 2 se emitirían los contenidos culturales, deportivos y de servicio público de baja audiencia de TVE.

Durante la etapa franquista, el ente público sirvió como instrumento de propaganda del régimen dictatorial, por lo que durante los años cincuenta y sesenta el gobierno español no percibió la oleada de capital que las televisiones privadas, en otros países, estaban obteniendo gracias al crecimiento de la publicidad. Por esta razón, terminó alejándose del ideal de servicio público imperante en Europa en ese momento. El modelo de financiación privada, el desinterés por la producción que promocionó la ficción estadounidense y la 
homogeneización de los contenidos por el control del régimen, caracterizaron esta etapa de la televisión pública española.

En la transición el patrón autoritario anterior se mantiene en un primer momento, la aprobación del Estatuto no cambió las cosas, y la televisión seguía siendo un aparato propagandístico, jerarquizado, centralizado y vertical.

La gubernamentalización del ente con el nombramiento de su director y el modelo financiero, sumado a una gestión ineficaz e incontrolada, contaminaron la televisión pública española en esta etapa. El clientelismo y la ambigüedad entre servicio público y financiación; la ambición de los políticos por mantenerse en el poder y la ausencia de un proyecto representativo de la pluralidad cultural de la nación y como espacio de la esfera pública, son las asignaturas pendientes que tuvo España comparándolo con otros países europeos de la época (Bustamante, 2006:52-53, 88-90).

Derivado del artículo 20.3 de la Constitución Española de 1978, que establece la organización y el control parlamentario de los medios de comunicación de titularidad pública, ve la luz el Estatuto de la Radio y la Televisión Española del 10 de enero de 1980. En él se declaran los servicios de radiotelevisión como servicios públicos esenciales (Soler, 2001:123). La ley 4/1980 englobó en el Ente Público RTVE las sociedades estatales Radio Nacional de España, Radio Cadena Española y Televisión Española.

Durante la primera etapa socialista el panorama radiotelevisivo público no cambió significativamente, continuó manteniendo una fuerte dependencia gubernamental y la organización y gestión, permanecieron ancladas en el autoritarismo.

Durante los años ochenta, se consolidó un modelo mercantilista en RTVE, algo insólito en Europa, que junto al clientelismo gubernamental y el monopolio que ostentaba la corporación no contribuyó en nada a fomentar la conciencia social con respecto al servicio público. A pesar de que durante los años noventa el déficit de RTVE creció, se siguió manteniendo ese modelo comercial que no hacía más que aumentar un endeudamiento amparado por el Gobierno. 
A esta coyuntura, hay que añadir el reparto de licencias a empresas privadas en función de intereses políticos y particulares, una oposición que sólo utilizaba la Comisión de control parlamentaria para descalificar al gobierno. Todos estos factores unidos a la falta de una autoridad independiente, que no fomentó el Gobierno de Felipe González, no ayudaron a mejorar el estado de RTVE, más bien hipotecaron la concienciación de servicio público.

La desregulación y la introducción de la competencia privada sin la previa adecuación del servicio público, llevó hacia la quiebra al ente (Op. cit. 2006:135-138).

Los mandatos del PP profundizaron todavía más en las políticas anteriores. La manipulación se convirtió en algo sistemático, la gestión con mucha influencia del Gobierno, y la transferencia del control a la SEPI (Sociedad Estatal de Participaciones Industriales), multiplicó casi por cinco el déficit de RTVE, y agravaron la comercialización. A pesar de ir en contra de la doctrina de la Comisión Europea, quien abrió un expediente.

Sindicatos, oposición y trabajadores del ente público se opusieron a la manipulación que sufrían por parte de sus directivos, colaboracionistas del Gobierno. Dichos directivos comenzaron a alternar su presencia entre los medios públicos y privados, generando un estándar de puerta giratoria.

Este modelo se expandió hasta las corporaciones autonómicas, el endeudamiento y la escasa financiación pública provocaron una exención gubernamental que se premió situando como directivos de los entes públicos de comunicación a miembros de los partidos en el poder.

En este periodo, el poder político llega a su máxima influencia en los medios privados a través tanto de la propiedad como la regulación de los mismos, extendiéndose también al mundo digital y al mercado de la comunicación. La concentración de medios estaba completamente desreglada, las concesiones se basaron en el clientelismo, y algunas compraventas de medios fueron dirigidas desde el Gobierno. Todo ello dio lugar a una fuerte concentración en el sector, aparecieron fuertes grupos multimedia que, con el apoyo del capital internacional, 
consiguieron mantener una posición dominante y minimizar la presencia de los medios españoles. No obstante, sigue existiendo la necesidad de una autoridad independiente que regule el espectro radiotelevisivo español.

Las empresas privadas no jugaron limpio en esta etapa, pues bajo la idea de servicio público indirecto, no dejan de ser empresas privadas, lo que les garantiza parte de su competitividad y autonomía ilimitada. Finalmente, y a pesar del control de medios públicos y privados ejercido por el PP y la utilización electoralista del 11-M, el PP no pudo salvarse de la derrota en las urnas (Ibíd. 2006:191-193).

En la etapa de Rodríguez Zapatero, se realizan diversas reformas como la Ley de la Radio y la Televisión Estatal de 5 de junio de 2006 (Ley 17/2006) que disolvió el ente y las sociedades TVE, S. A., y RNE, S. A. creando la actual Corporación RTVE. Una de las novedades de esta ley fue el nombramiento del Director General de RTVE. En un intento de dar más independencia al ente, se decidió que en lugar de ser nombrado por el Gobierno, debería ser elegido en el Parlamento. En una primera vuelta era suficiente la mayoría simple y en el caso de necesitar una segunda votación, se aprobaba con dos tercios de la Cámara. Esta medida tuvo buena acogida entre los trabajadores del mismo, que lo vieron como un intento de despolitización del ente.

Hay que mencionar además que, gracias a la Ley 17/2006 y a la disposición de la dirección de informativos con Fran Llorente a la cabeza, salió adelante el Estatuto de Información en 2008, del que posteriormente surgió el Consejo de Informativos de TVE, un organismo que hace el papel del Trust en la BBC. Velando por el cumplimiento de la deontología de la información y de la libertad de expresión de los profesionales de RTVE.

El Consejo de Informativos está funcionando día a día, como demostró al frenar el intento de control político del Consejo de Administración de RTVE a través del sistema de creación de noticias E-NEWS. Sin embargo, su incipiente creación y los intentos de presión que sufren los trabajadores de manera habitual, denotan que todavía estamos muy lejos de la independencia de la que goza la 
televisión pública británica, pero desde luego fue un paso hacia delante que se ha visto frenado con el último cambio de gobierno.

Al mismo tiempo, el Gobierno de Zapatero, puso en marcha un polémico plan de reestructuración y saneamiento de RTVE que redujo la plantilla en 4.855 trabajadores mediante jubilaciones anticipadas y bajas incentivadas, a pesar de ser uno de los grupos de radiotelevisión públicos con menos personal en Europa ${ }^{43}$.

\section{NÚMERO DE EMPLEADOS EN ENTES PÚBLICOS DE LA UE}

\section{$B|B| C$}

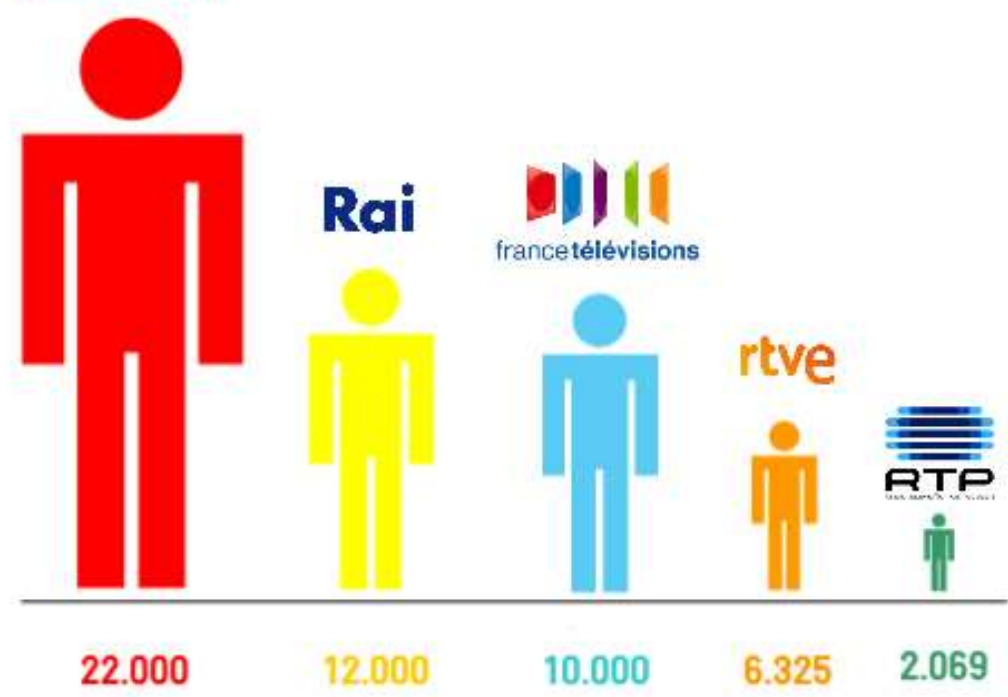

Elaboración propia.

Ilustración 7. Nivel de capital humano de RTVE y otras corporaciones públicas europeas

\section{Diferencias de financiación}

En 2009 el Gobierno presentó su Anteproyecto de Ley de Financiación de la Corporación RTVE, basado en el modelo francés,

\footnotetext{
${ }^{43}$ Noticia consultada el 12-06-2014 en http://www.huffingtonpost.es/2013/06/12/situacion-televisionespublicaseuropa n 3429772.html
} 
que suscitó críticas sindicales por la falta de consulta a otros organismos e instituciones, así como por la implantación de forma inmediata y no progresiva, como sucediera en Francia (Jivkova, 2011:76).

Los españoles son los únicos ciudadanos europeos que no pagan un canon por el servicio de radiotelevisión pública. La financiación de la televisión pública española limita la producción de la televisión, pues su presupuesto se reduce a lo estipulado en los Presupuestos Generales del Estado, que "si lo dividiéramos entre todos los españoles serían aproximadamente unos diez euros por persona al año, mientras que en la BBC la cantidad supera los cien euros ${ }^{44}$ por familia", alega el ex director de Programación y Gestión de Informativos de TVE ${ }^{45}$, Xavier Obach.

Si se planteara a los ciudadanos el modelo de la BBC, creo que muy pocos concebirían la idea de que eso ocurriera en España, dirían: ¿pagar por ver la televisión?, ¡si la tenemos gratis! Y creo que ese es el error, los españoles nunca hemos tenido conciencia de lo público, nada es gratis, sale de los impuestos que nosotros mismos pagamos, ahora bien, el desinterés por unos presupuestos poco detallados y la desinformación a la que nos someten los políticos e instituciones, son la causa de esa sensación de gratuidad. La falta de transparencia en nuestro sistema posibilita esta creencia y además nos deja indefensos ante un mejor o peor reparto del presupuesto en cada partida. Sin embargo, si hubiese un canon como en el Reino Unido sería más fácil definir cuánto dinero se destina a RTVE.

Por otro lado, en este periodo de crisis económica, social y política en el cual nos encontramos, es difícil defender la necesidad de una información libre, plural y de calidad para todos. Son la sanidad, la educación y el empleo los principales derechos que garantizar, como no puede ser de otro modo, pero no por ello es menos importante que la sociedad esté bien informada. La influencia de los medios de

\footnotetext{
${ }^{44}$ Concretamente 145.50 libras por familia. Tasa congelada desde 2010 hasta 2016 (Dato de Licence Fee en la Web oficial de BBC).

${ }^{45}$ Desde el 23 de abril de 2013 este cargo lo ostenta Miguel Ángel Toledo, tras la dimisión de Cecilia Toledo, quien envió por error un email al Consejo de Informativos criticando a sus propios miembros.
} 
comunicación es muy fuerte y juega un papel determinante para la formación del pensamiento crítico en la sociedad.

El modelo de financiación de RTVE ha sido mixto, con ingresos publicitarios y ayudas públicas. Desde enero de 2010 esto cambia tras la decisión de Zapatero ${ }^{46}$ de suprimir la publicidad privada en los canales de RTVE, su funcionamiento comienza a ser financiado mediante una partida de los Presupuestos Generales del Estado que cubre el 50\% de los gastos. El 50\% restante proviene de un impuesto extra del $0,9 \%$ a las compañías de telecomunicaciones, el 3\% de los ingresos de las televisiones privadas abiertas y el 1,5\% de las televisiones de pago. Asimismo, el ente percibe el $80 \%$ de lo recaudado por la tasa sobre reserva de dominio público radioeléctrico regulada en la Ley General de Telecomunicaciones, los ingresos obtenidos por el ejercicio de sus actividades y la comercialización de sus servicios y productos.

Con todas estas medidas insuficientes y el déficit adquirido durante años, se generó una deuda que debe asumir el Estado. Por ello en $2012^{47}$, el Gobierno popular de Mariano Rajoy decidió recortar los ingresos gubernamentales para el ente un 21,6\% menos de lo que la Ley de financiación de RTVE de Zapatero había establecido en un primer momento. Esta bajada de ingresos se ha mantenido hasta la actualidad $^{48}$.

Los presupuestos son una de las grandes diferencias entre el ente británico y el español. RTVE es un órgano dependiente del poder político que además tiene unos recursos mucho más limitados que la $\mathrm{BBC}$, que se refleja en la calidad y variedad de sus producciones. Con

\footnotetext{
${ }^{46}$ Ley 8/2009 de 28 de agosto, de Financiación de la Corporación de Radio Televisión Española

${ }^{47}$ Presupuestos 2012 RTVE consultado el 19-10-2013 en http://www.prnoticias.com/index.php/television/185-tve-/20113406-elpresupuesto-de-rtve-para-2012-es 245 -millones-y-mas-de-un-20-inferior-al-de$\underline{2011}$

${ }^{48}$ Noticia consultada el 18-02-2014 en http://www.formulatv.com/noticias/33200/rtve-apruebapresupuesto-2014cifrado-940-millones-euros/
} 
más de tres mil millones de libras ${ }^{49}$ el Grupo BBC puede realizar contenidos de alta calidad gracias a cuya venta a otras televisiones de todo el Mundo, se convierte en una fuente de financiación muy importante.

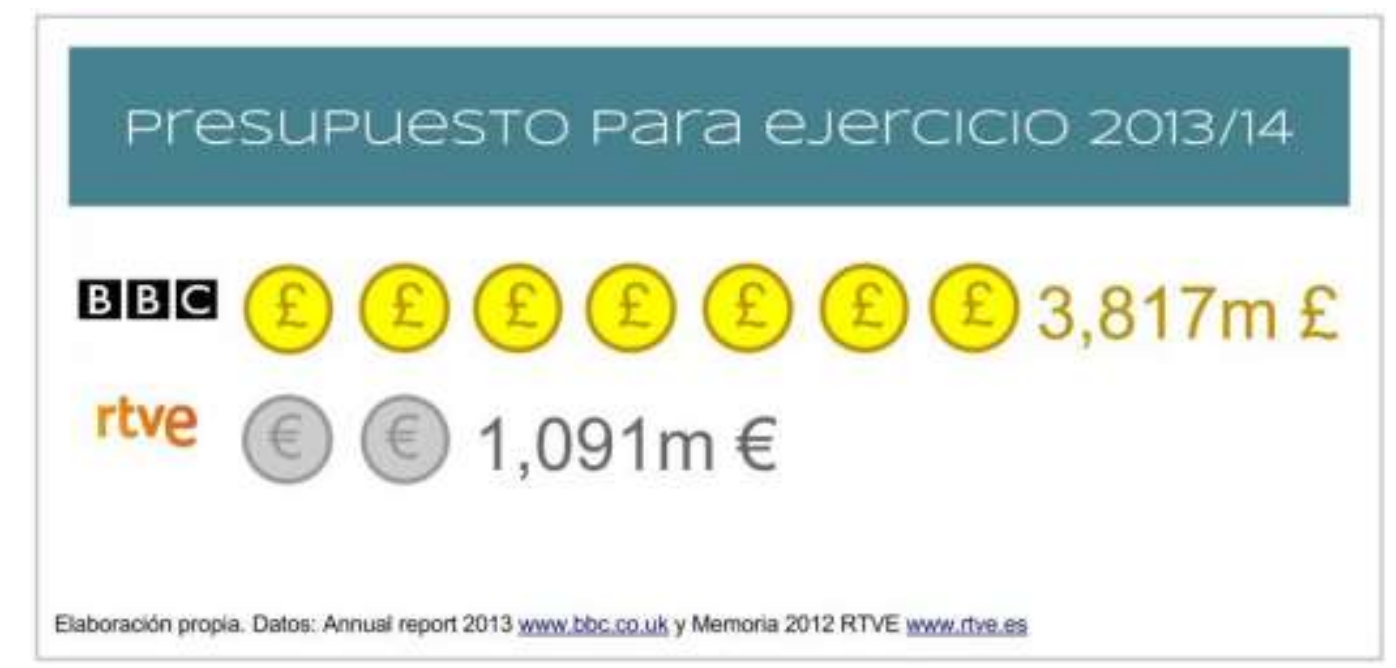

Ilustración 8. Comparativa presupuestaria entre RTVE y BBC.

Si bien, los ingresos de RTVE dependen en gran medida del Gobierno, que según el partido que se encuentra en el poder, influye en mayor o menor grado en su independencia. Igualmente, no tiene capacidad $^{50}$ para crear productos de tanta calidad que puedan retroalimentar el funcionamiento del ente público y aumentar sus ingresos. Es un bucle del que, en principio, no podrá escapar RTVE si no cambia la dinámica del modelo de financiación, pues se trata de un lastre que todavía hoy sigue pendiente de resolverse y "la televisión es un negocio que debe ser rentable en lo económico y en lo social" (Estrella, M y Rincón, O; 1999: 61).

Por otro lado, el nacimiento de la TDT, supuso que Televisión Española fuera el principal motor del desarrollo de la televisión digital en España, tras la implantación de La 1, La 2, 24h, Teledeporte, Clan, Canal Parlamento y TVE HD. Del mismo modo

\footnotetext{
${ }^{49}$ Annual report 2012 - BBC Group consultado el 21-09-2013 en http://www.bbc.co.uk/annualreport/2013/executive/ finances/chief-financialofficers-review.html http://downloads.bbc.co.uk/annualreport/pdf/201213/bbc-full-financial-statements-2012-13.pdf

${ }^{50}$ Memoria anual 2012 RTVE consultado el 03-05-2013 en http://www.rtve.es/files/70-38062FICHERO/MEMORIA2012.pdf
} 
TVE Internacional y $24 \mathrm{~h}$ puede verse vía satélite y de manera gratuita en todo el Mundo.

Pero la situación actual resulta desoladora para las televisiones públicas en España. Los ERES, las privatizaciones y la actual desregulación en cuanto a concentración mediática nos dejan un futuro poco alentador, con pocas oportunidades de tener una información de calidad y para todos los ciudadanos.

\section{Privatización de las televisiones públicas}

En 2010, a través de la Ley General de Comunicación Audiovisual (LGCA), el Gobierno de Rodríguez Zapatero blindó la posibilidad de privatizar las televisiones autonómicas, sin embargo, en 2012 el Gobierno de Mariano Rajoy abrió la puerta para que las Comunidades pudieran vender sus corporaciones ${ }^{51}$. La "Ley de modificación de la Ley 7/2010 de 31 de marzo, para flexibilizar los modos de gestión de los servicios públicos de comunicación audiovisuales", se aprobó con el voto a favor del PP, la abstención de CiU y el rechazo del PSOE, CHA (en nombre de la Izquierda Plural), UPyD y ERC ${ }^{52}$.

Con esta modificación de la Ley 7/2010 los gobiernos autonómicos podrán decidir si la gestión de sus televisiones es: pública, gestionada con sus propios recursos técnicos y humanos; externalizar algunos servicios, como la producción de programas, la publicidad, etc.; o sacar a concurso una licencia que se cederá a un operador privado. Todo esto con la excusa de limitar el presupuesto de los trece entes regionales, que en total suponen una veintena de canales de radio y televisión.

Los ejecutivos de Castilla La Mancha y Madrid ya han decidido que la privatización es la solución para sus corporaciones mediáticas. Por su parte, la Comunidad Valenciana optó por el modelo mixto hasta el

\footnotetext{
${ }^{51}$ Noticia consultada el 24-06-2013 en

http://sociedad.elpais.com/sociedad/2012/04/20/actualidad/1334934731 620534.html

${ }^{52}$ Noticia consultada el 12-05-2013 en http://www.elmundo.es/elmundo/2012/06/07/comunicacion/1339071601.ht $\underline{\mathrm{ml}}$
} 
cierre de RTVV. Sin embargo, desde el Gobierno andaluz se sigue apostando por la continuidad del modelo público en el que la gestión dependa exclusivamente de la Junta de Andalucía.

Cabe decir, que desde 2012 las productoras se han afanado en tomar posiciones para quedarse con parte del pastel de las autonómicas. Las más importantes son Vértice $360^{\circ}$, que gestiona la continuidad en la televisión pública de Canarias y ha conseguido adjudicaciones en Castilla La Mancha y Aragón a través de Videoreport; y Grupo Secuoya, que compró Vnews (agencia de noticias de Antena 3) para ofrecer servicios externos a las autonómicas en un futuro cercano.

Además de estas alianzas y adquisiciones corporativas, comenzaron a incorporarse personas influyentes a sus plantillas o consejos de administración. Este fue el caso de Secuoya que cuenta con Miguel Ángel Rodríguez, exsecretario de Estado de Comunicación con Aznar, o Santiago González, ex director de TVE. El objetivo es que actúen como lobbies de presión, de tal modo que las compañías tengan una mayor fuerza en futuras negociaciones con las televisiones públicas a las que presentaron su oferta ${ }^{53}$.

De la misma forma, a través de su filial CBM (Central Broadcaster Media) ya gestiona los informativos de la televisión pública balear IB3 y las coberturas informativas de Telemadrid. ${ }^{54}$

Privatizar las televisiones autonómicas supone perder un espacio que en teoría es de todos y para todos, donde los distintos grupos que forman una sociedad deben tener su lugar y verse representados. Al mismo tiempo es una forma más de ceder un nicho económico a los grandes empresarios de siempre, en muchos casos, personas cercanas al poder ejecutivo de turno.

\footnotetext{
${ }^{53}$ Noticia consultada el 13-06-2013

http://ccaa.elpais.com/ccaa/2013/04/11/valencia/1365696399243615.html? $\underline{\mathrm{rel}}=\mathrm{rosEP}$

${ }^{54}$ Noticia consultada el 15-06-2013 en http://sociedad.elpais.com/sociedad/2012/08/27/actualidad/1346091419 37 2027.html
} 
Al fin y al cabo, las televisiones públicas se están convirtiendo en otro jugoso pastel que repartir. Es un negocio redondo para el sector privado, pues hay que tener claro que las empresas que se privatizan son las más rentables, los grandes empresarios no son tontos y por ello sólo compran las empresas públicas que producen beneficios. Compran muy barata una empresa que ha sido creada con recursos públicos, para luego explotarlos a mayor precio.

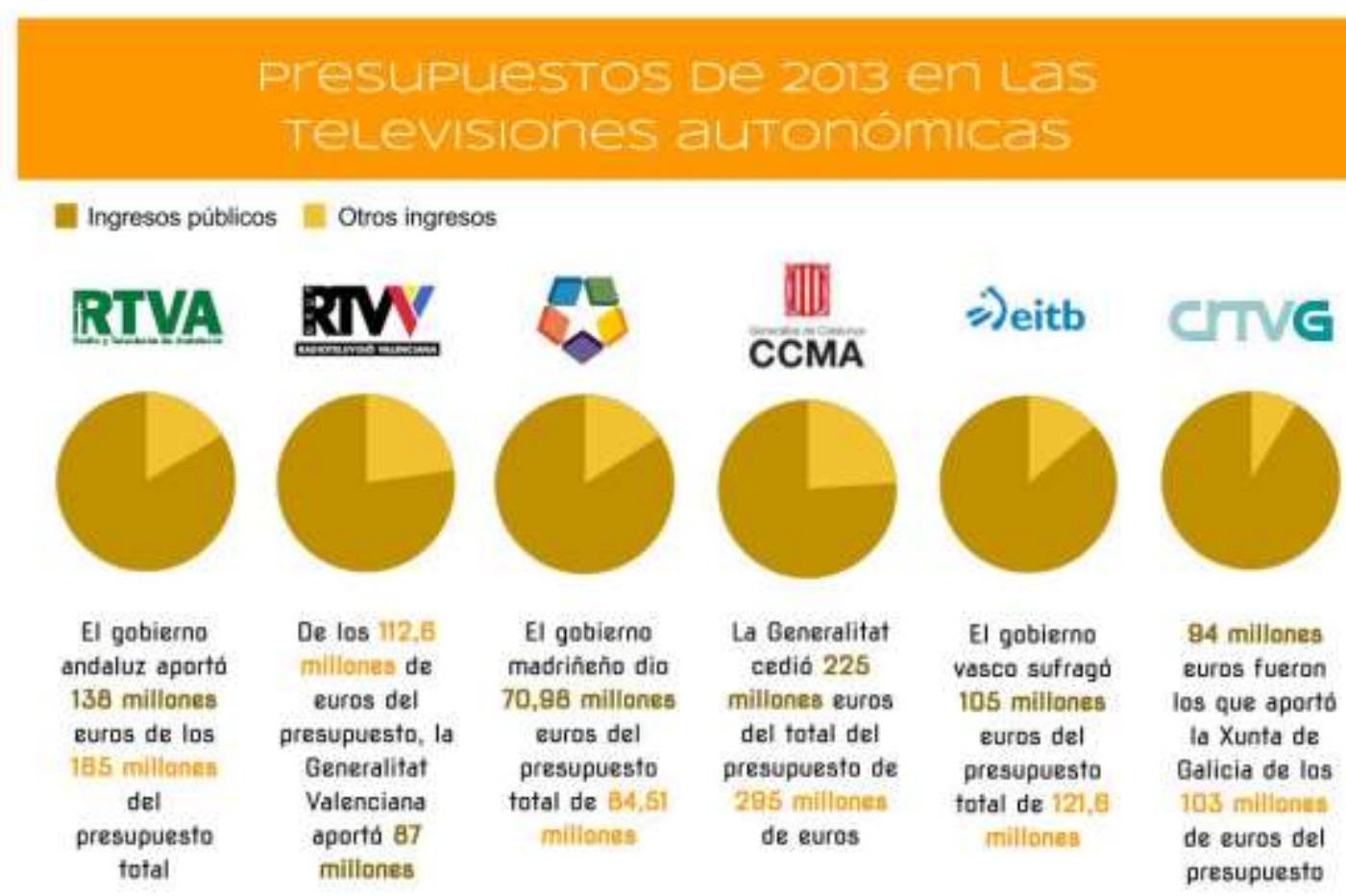

Elaboración propia. Datos: mwer.aletodalalcom y wmw elpais.com vebse bittiografia

Ilustración 9. Ejemplos de capital público y privado en los presupuestos de corporaciones autonómicas.

Como podemos observar en el siguiente gráfico ${ }^{55}$, el dinero que los gobiernos autonómicos invierten en sus televisiones públicas garantiza la existencia de las mismas y que ofrezcan un servicio público a pesar de que en ocasiones, como en el caso de Canal 9, no fuera el objetivo principal.

\footnotetext{
${ }^{55}$ Diferencias presupuestarias de 2013 entre las distintas televisiones autonómicas consultados el 13-09-2013 en

http://ccaa.elpais.com/ccaa/2013/03/15/andalucia/1363343799 812790.htm l? rel=rosEP http://www.alertadigital.com/2013/07/01/el-presupuesto-detv3-supera-al-de-rtve/
} 
Quizá el error estuvo en crear unas televisiones autonómicas que se convirtieron en un feudo de los gobiernos regionales, sin supervisión externa de un órgano competente como podría ser el Consejo Audiovisual. Institución que continúa siendo reclamada por gran parte del sector y que ningún gobierno ha materializado a día de hoy.

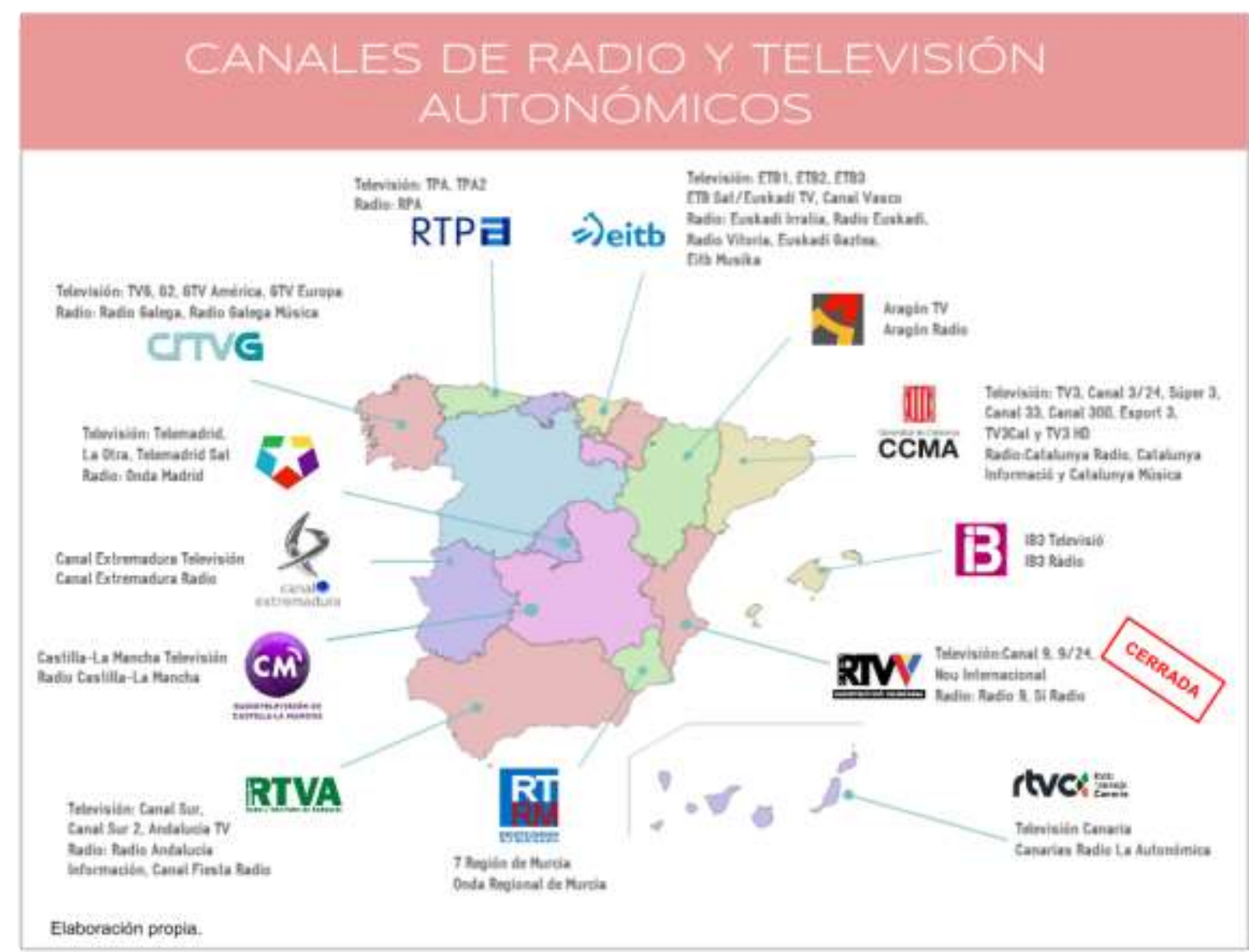

Ilustración 10. Mapa de las radiotelevisiones públicas autonómicas en España.

¿Por qué no se planteó un modelo centralizado como el de la BBC? Podríamos pensar que esto tampoco evitaría el problema de la instrumentalización política, pero sería más fácil unificar criterios y vigilar a una sola institución que a diecisiete. Concretamente, fue absurdo desaprovechar la gran infraestructura de la que disponía ya RTVE. De hecho, se hubieran evitado duplicidades como las desconexiones territoriales en los informativos de RTVE.

Una de las razones que sustentaban la creación de las televisiones autonómicas fue la identidad lingüística. En cambio, con el paso del tiempo se ha comprobado que no ha sido una prioridad para muchas 
de ellas, exceptuando Televisión Catalana (TVC) y el primer canal de ETB (Euskal Telebista) cuyas programaciones son íntegramente en catalán y euskera respectivamente. (Moragas et. al. ,1999:170-178)

En España coexisten 13 operadores públicos regionales de radiotelevisión. Excepto Navarra, Castilla y León, Cantabria y La Rioja, todas las comunidades autónomas cuentan con una corporación mediática que engloba en casos como la catalana CCMA, hasta 8 canales de televisión.

En Reino Unido existen fuertes diferencias regionales y nacionales. A pesar de ser una Mancomunidad de Naciones centralizada en el Parlamento de Westminster, en Londres (Inglaterra), las capitales del resto de Naciones (Escocia, Gales e Irlanda del Norte) que la componen albergan sus propios parlamentos, que tienen competencias legales, educativas, sanitarias y sociales.

Las directrices del ente británico establecen en su capítulo 2 los valores que deben seguirse con respecto a dichas diferencias:

"En el Reino Unido hay diferentes sensibilidades nacionales y regionales que debemos respetar y atender en nuestro trabajo [...] Debemos ser precisos, exactos y coherentes en nuestra cobertura de los hechos y evitar estereotipos o clichés.

Cualquier productor de contenidos que pretenda producir programas sobre Irlanda del Norte o proyectos importantes que traten sobre la República de Irlanda debería cambiar impresiones sobre sus planes lo antes posible con el responsable del área de Irlanda del Norte. De igual manera, los productores de contenido que no se encuentren en Escocia $\mathrm{o}$ en Gales deben informar por escrito al responsable de área de esas naciones sobre sus proyectos de producir material que se refieren de manera relevante a asuntos y temas de esas naciones o que aluden a ellas.

En asuntos concernientes a las naciones y regiones, el responsable del área debe recibir información sobre toda 
cuestión que sea de consulta obligatoria con el responsable de Política Editorial.” (BBC, 2007:7)

La cuestión es realizar un trabajo independiente y plural, que respete a todos los ciudadanos que integran un Estado y desde luego nuestras televisiones públicas no lo han conseguido hasta el momento, ni RTVE ni las autonómicas.

No obstante, podríamos haber buscado un modelo más eficiente para optimizar los recursos y atendiendo a la misión de servicio público en vez de a criterios meramente electorales como parece que sucedió, pues "el café para todos" también tuvo lugar en el sector audiovisual de manera que,

"el nacimiento de las televisiones públicas regionales no es sino el fruto del proceso de configuración del estado español como un Estado Autonómico" (Manfredi et. al, 1999).

Las televisiones públicas deberían seguir funcionando por y para los ciudadanos, y aunque su coste sea elevado deberíamos optimizar sus cuentas, y sobre todo conseguir que realicen su función de servicio público. Pero desde luego privatizarlas no es una solución que favorezca a la ciudadanía, que ha invertido con sus impuestos en la creación de estos entes y que actualmente están contemplando como las empresas privadas se benefician de todos sus recursos. Si algo no funciona habría que replantear el modelo y solucionar los problemas existentes. Debemos ser conscientes que la salida rápida que algunos gobiernos autonómicos plantean está pensada sólo para favorecer al sector privado de la comunicación, no a los ciudadanos.

\section{Televisión pública partidista}

Actualmente la Corporación RTVE tiene naturaleza jurídica de sociedad anónima y su capital social es de titularidad íntegramente estatal. A pesar de que es institucionalmente independiente respecto del Gobierno y la Administración General del Estado. No ocurre lo mismo económicamente, ya que pertenece indirectamente a la SEPI (Sociedad Estatal de Participaciones Industriales), que depende del Ministerio de Hacienda y Administraciones Públicas, es decir, del Gobierno. 
Una de las primeras acciones del PP en RTVE fue el nombramiento de Leopoldo González Echenique al frente de la corporación como presidente (2012-2014) $)^{56}$, quien cesó al director de Informativos de TVE, Fran Llorente, poniendo en el cargo a Julio Somoano. A estos cambios en la dirección se sumaron el cese de los editores del Telediario 1, 2 y de Fin de Semana: Pepa Rodríguez, Pepa Bueno y Miguel A. Hoyos respectivamente, y el de Ana Pastor como directora y presentadora de 'Los Desayunos'. Además de otros profesionales del ente como Toni Garrido, Juan Ramón Lucas o Xabier Fortes que también fueron apartados de RTVE tras la llegada de la nueva dirección del ente.

Finalmente, si comparamos nuestras televisiones con la BBC, concretamente los entes públicos que se analizaron (RTVE y RTVV) en la tesis doctoral que nutre este ensayo. Cabe decir que la radiotelevisión valenciana estaba muy lejos de tener los mecanismos de autorregulación de la BBC, puesto que sólo contaba con el Estatuto de creación de 1984, "papel mojado" según un periodista de RTVV que prefería mantener su anonimato por el efecto ERE.

Además, no contaba con un código de regulación específico sobre las directrices editoriales, ni con consejos que protegieran la independencia de sus profesionales y de su audiencia en el momento de la investigación. Si bien es cierto que con el primer Gobierno del PPCV en 1995, RTVV tuvo un Consejo de Redacción para garantizar la independencia de los trabajadores, para el expresidente del Comité de empresa de RTVV, Vicent Mifsud ${ }^{57}$ :

"A la empresa le interesó para decir que habían fomentado la creación de un órgano que garantizaba la pluralidad en la televisión, pero pasados tres años y después del efecto propagandístico y de ver que ese organismo ponía en evidencia la manipulación que había, la empresa presionó a la gente para que no se presentara nadie para formar parte de él".

\footnotetext{
${ }^{56}$ Su sucesor como Presidente de RTVE fue José Antonio Sánchez Domínguez (2014-actualidad)

${ }^{57}$ Entrevista personal realizada en Valencia el 13 de junio de 2011.
} 
Las presiones y el hecho de que tuviera que renovarse anualmente con una plantilla "muy presionada" por la dirección del ente valenciano "sobre todo después de la penúltima mayoría de Camps", propició que la situación fuera "de control férreo y al servicio de la empresa", afirma Mifsud.

Los profesionales de RTVV sabían muy bien lo que es realizar su trabajo bajo la supervisión de la dirección en temas sensibles para el PPCV como: el 15M, el accidente de metro de Valencia, o la aparición de ex líderes del partido que no eran ya bien recibidos en seno del PP valenciano.

En cuanto a RTVE la situación era algo más alentadora en el momento de la investigación. A pesar de que queda mucho camino para llegar a la estructura del ente británico, la corporación española cuenta con un Manual de Estilo en el que se recogen los principios editoriales para el tratamiento de temas más sensibles: los menores, la política, violencia, género, terrorismo, etc. así como cuestiones específicas relacionadas con medios interactivos, la radio, la televisión y el lenguaje.

Este manual puede ser comparable a las directrices editoriales de la BBC que apuntan a diversos aspectos como la legalidad (derecho a la intimidad, responsabilidad social, daños y perjuicios), el tratamiento de temas delicados (menores, guerra, terrorismo, política, religión, justicia) o valores profesionales (exactitud, precisión, imparcialidad, diversidad de opinión, integridad editorial e independencia).

Como explicó para la investigación la ex editora del Telediario 1 de TVE, Pepa Rodríguez, "como periodista tenemos la misma independencia que la $\mathrm{BBC}$, el problema es que la empresa no tiene el mismo grado de independencia". A tenor de estas declaraciones, es importante contemplar el grado de independencia de la empresa informativa. En este caso y después de ver el recorrido histórico de RTVE podemos afirmar que nunca ha sido independiente del Ejecutivo. 
Esta última etapa de RTVE nos ha dejado claros ejemplos de ello ${ }^{58}$ :

1. Manipulación gráfico descenso del paro. El Telediario 1 del 3 de septiembre de 2013 abre con los datos de descenso del paro con un gráfico cuya curva no se correspondía con los números (que sí eran correctos). Se apreciaba una curva exagerada que dejaba intuir que el paro había bajado casi al $0 \%$

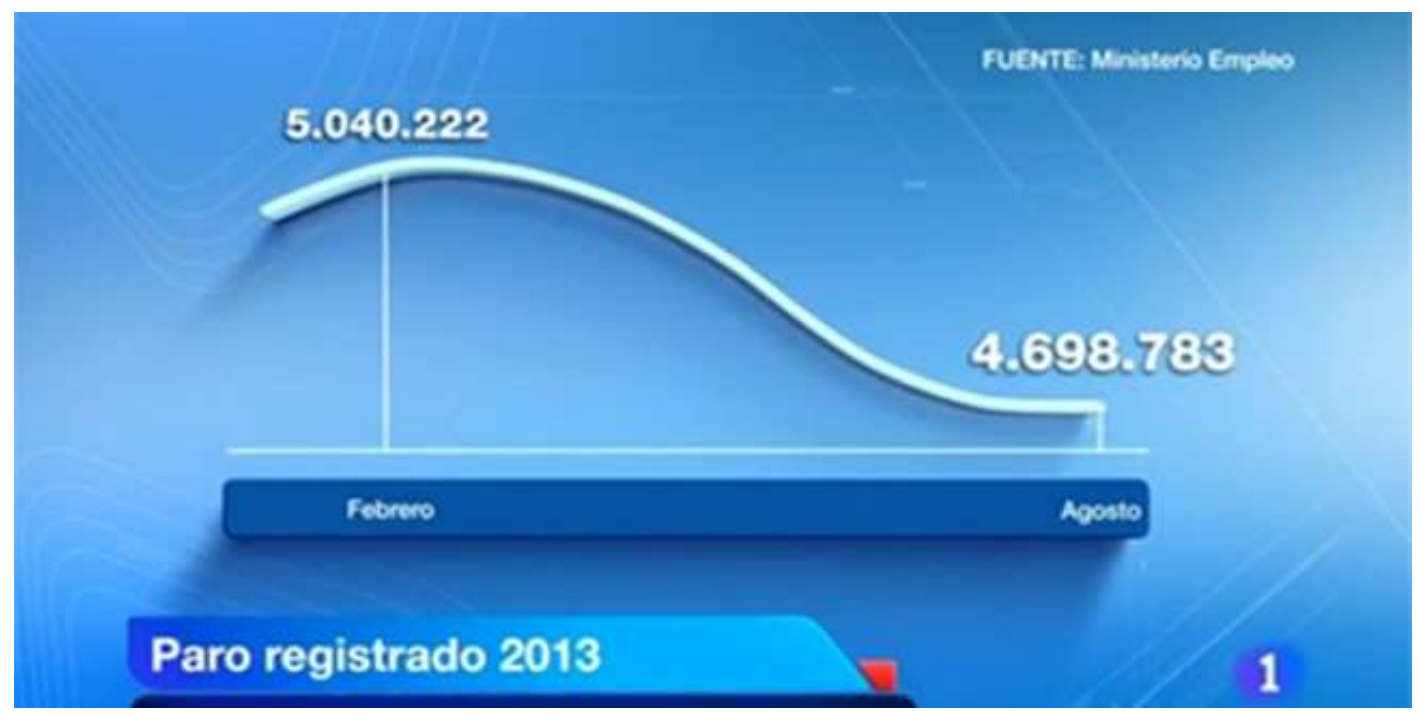

Ilustración 11. Imagen del gráfico manipulado sobre la tasa de paro emitido en La $1^{59}$.

2. Mantener la atribución del 11M a ETA. El 29 junio 2013 en el programa Parlamento de Canal 24horas se volvía a atribuir el atentado del $11 \mathrm{M}$ a ETA afirmando: "hace ya más de tres años que ETA no comete ningún acto violento, aunque permanecen grabados en nuestra memoria atentados como el de Hipercor o el 11M". De este modo RTVE mantiene la línea argumental que tuvo el PP y que finalmente se demostró que era falsa.

3. La iglesia es la solución. El Telediario 2 del 7 de mayo de 2013 cerró con una noticia sobre las cererías y la

\footnotetext{
${ }^{58}$ Noticia consultada el 20-09-2013 en http://www.vayatele.com/tve-1/cincoacusaciones-demanipulacion-hacia-la-actual-tve

${ }^{59}$ Imagen recuperada el 12-06-2014 de http://i.blogs.es/2faf23/grafico3deseptiembre/original.jpg
} 
crisis. La presentadora la introducía diciendo: "según los psicólogos acercarse a un altar puede ayudar a calmar la ansiedad por la falta de trabajo o el temor a perderlo".

4. Ley de costas. En el Telediario 1 del 9 de mayo de 2013 se realizaron dos reportajes sobre las detenciones de miembros de Greenpeace por manifestarse en el Congreso de los Diputados y otro alabando la citada ley sin presentar las voces en contra. Este hecho, llevo a la propia presentadora, Ana Blanco, a quejarse por el tratamiento del tema.

5. Escraches a políticos. En el programa Informe Semanal del 27 de abril de 2013 se realizó un reportaje sobre los escraches que la Plataforma de Afectados por la Hipoteca $(\mathrm{PAH})$ realizaba a los políticos. En él se vertieron muchas informaciones negativas sobre la $\mathrm{PAH}$ sin recoger declaraciones de sus integrantes hasta el final, donde apenas apareció su presidenta. El Consejo de Informativos interpuso una queja por la falta de proporcionalidad de este reportaje, que además incumplía las normas del Estatuto de Información y el Manual de Estilo de la corporación.

Estas políticas informativas han sido rechazadas por gran parte de los ciudadanos, como demuestra la caída de audiencia sufrida por RTVE desde que Julio Somoano dirige los informativos. En octubre de 2012 ya habían perdido 525.000 espectadores en la segunda edición y 311.000 en la primera edición, presentada por Ana Blanco. Estos datos, dejaron patente que la nueva línea editorial no está siendo respaldada por los ciudadanos. Mientras los informativos de La Sexta, Salvados y Al Rojo Vivo ganaron audiencia ${ }^{60}$

A pesar de llevar más de tres décadas en Democracia, queda un largo trecho para poder equiparar los medios públicos españoles a la estructura corporativa de la BCC, para ser empresas que garanticen el cumplimiento de los valores del mejor periodismo y del servicio

\footnotetext{
${ }^{60}$ Noticia consultada el 25-12-2013 en http://www.periodistas21.com/2012/11/los-telediarios-de-tvepierdenmedio.html
} 
público. Podemos decir incluso, que la televisión de todos retrocede en el tiempo más que nunca.

El Consejo de Administración es un instrumento del poder político para controlar o en su defecto vigilar la actividad profesional de RTVE. Hay que ser conscientes de que la televisión pública española ha sido utilizada por todos los gobiernos, sin excepción, que hemos tenido y ese el gran obstáculo. Un problema que parece endémico, del que no podemos escapar y que somete a la ciudadanía a la información única y sectaria de la que es difícil no contagiarse.

Como sociedad, propietaria además de esa empresa pública, debemos luchar por una información pública para todos. Una radiotelevisión en la que todos los grupos sociales estén presentes, donde todas las ideas estén reflejadas, porque al fin y al cabo la televisión pública es de todos por derecho.

Teniendo en cuenta el aumento de la concentración de medios en el sector privado, cada vez es más difícil obtener una información plural. Estar bien informado cuesta, pues es necesario hacer un esfuerzo para encontrar diferentes voces.

Además de la falta de pluralidad informativa y de agentes comunicativos independientes, el ciudadano se encuentra con otro inconveniente para poder informarse bien: la gran cantidad de información que existe hoy en día, sobre todo en Internet. Que dispongamos de mucha información no significa que sea plural y veraz, pues la cantidad no garantiza la calidad. Cómo diferenciar la información buena de la mala, es otro de los factores que dificulta a los ciudadanos el derecho de estar bien informados.

Una persona que quiera conocer la mayor cantidad de puntos de vista, saber todo lo que ocurre sin censura y finalmente formarse su propia opinión sobre un tema, tiene una tarea ardua por delante, y no todo el mundo está dispuesto a realizarla. Ahora bien, si las personas que de verdad son conscientes de la importancia de estar bien informados, deciden ponerse manos a la obra, tendrán que saber separar la paja del grano en el contexto de "sobreinformación/ infoxicación" al que estamos sometidos de forma continua y que paradójicamente no beneficia, distorsiona. 
Actualmente en Internet encontramos información que no sólo viene de los medios de comunicación tradicionales, los únicos que seleccionaban la información hasta hace unos años. También los propios ciudadanos aportan contenido en la red, a través de las redes sociales, los blogs, comentarios en las noticias, etc. Este nuevo contexto en la Sociedad de la Información favorece la "infoxicación" pues el lector no tiene tiempo para constatar la veracidad de tanta información (Caldevilla, 2013).

Por ello y aunque parezca que vivimos en una sociedad más informada, gracias sobre todo a la accesibilidad que nos da Internet, no es más que un espejismo ya que la sobreinformación nos sume en un caos en el que resulta complicado encontrar la verdad.

De este modo, la función de las televisiones públicas debería ser más valorada que nunca por los ciudadanos. Tenemos derecho a que una empresa que pagamos todos, sea por y para todos pues podemos exigirle su deber de servicio público. En cambio, en el sector privado no podemos interferir, cada medio elige la línea editorial que estima oportuno según sus intereses, pero en un medio público sus intereses deberían ser los ciudadanos.

Por tanto, el discurso demagógico: las televisiones públicas no sirven para nada, son un derroche, es mejor cerrar una televisión que un colegio, etc. que algunos sectores sociales intentan vender, no tiene sentido. Una televisión pública de calidad es tan importante como un colegio, un hospital o cualquier otro derecho. No olvidemos que la información que tenemos de nuestro entorno nos forma como individuos e influye en última instancia, en nuestra elección política en cuanto a los representantes que gestionan el sistema en el que vivimos.

Si una televisión pública no funciona sería aconsejable solventar los errores y mejorarla, pero su cierre es una salida cómoda que atiende a los intereses de ciertos políticos en detrimento de los ciudadanos. 



\section{Cómo se cierra una televisión pública: El caso de Canal 9}

R ADIO Televisión Valenciana (RTVV) se creó bajo el amparo R del Estatuto de Autonomía de la Comunidad Valenciana, aprobado por ley orgánica el 1 de julio de 1982. Éste señala, en su artículo 37, la potestad de la Generalitat para crear, regular y mantener cualquier medio público de comunicación social para el cumplimiento de sus fines, dentro del marco legislativo del Estado.

Antes del nacimiento de Canal 9 en 1989, la Comunidad Valenciana tenía programación autonómica propia en La 2 , gracias al centro regional de $\mathrm{TVE}^{61}$. Según determina el propio Estatuto de Autonomía, éste debía articular una programación específica en un régimen transitorio hasta tener el canal autonómico propio. Sin embargo, con la promulgación de la Ley del Tercer canal en 1983 y la posibilidad de crear un tercer canal de TVE para las desconexiones territoriales, las autonomías se apresuraron a crear sus propias televisiones, para evitar la dependencia centralista con RTVE.

En 1983, Les Corts valencianas afrontaron la Ley de Creación de Radio Televisión Valenciana a los tres meses de ser promulgada la Ley de Tercer Canal. En febrero de 1984 Alianza Popular presentó un primer borrador, muy parecido al Estatuto de RTVE y la Ley

${ }^{61}$ Desde 1974 se realizaban pequeños informativos bajo el nombre de Aitana. Actualmente RTVE emite los informativos territoriales a las 14.00 horas y después del informativo nacional, a las 16.00 horas, sin ser íntegramente en la lengua autonómica, en este caso valenciano. 
creadora de la Corporación Catalana de RTV, proponiendo una comisión mixta compuesta por miembros del ente público RTCV (Radiotelevisión Comunidad Valenciana) y de RTVE, con el objetivo de poner en funcionamiento el tercer canal autonómico. Dicha propuesta fue rechazada en Les Corts con la mayoría del PSPV, quienes propusieron un nuevo proyecto sin referirse a la Ley del Tercer canal, amparándose en el artículo 37 del ya mencionado Estatuto, que obligaba a "fomentar el desarrollo de las peculiaridades del pueblo valenciano", siguiendo el ejemplo de Madrid y Andalucía.

El proyecto reproducía literalmente gran parte del articulado del Estatuto de la Radio y la Televisión Española, con una salvedad importante, en el artículo 2.1.a que antepone "la promoción y protección de la lengua propia de la Comunidad Valenciana" y el artículo 7.1.a que dictamina que corresponde al Consejo de Administración proponer al Consell de la Generalitat el nombramiento y cese del director general, el cual sólo podrá designarlo libremente si el Consejo de Administración no consigue una mayoría de dos tercios del Consejo de Administración o, transcurrido un mes después, por mayoría absoluta según el artículo 8.2. Finalmente, en 1984 el anteproyecto de ley se aprobó por unanimidad, aunque con algunas matizaciones del grupo parlamentario de Alianza Popular que acusó al gobierno central de falta de voluntad política y puso en duda el modelo de financiación mixta (A. Cubells, 2002:38-40).

José $\mathrm{M}^{\mathrm{a}}$ Anchells Cubells explica en su tesis doctoral, los modelos que la Dirección General de Medios de Comunicación Social (DGMCS) de la Generalitat Valenciana consideró para crear la televisión valenciana:

Modelo A:

- La producción propia se fundamenta en los informativos (plenos y de ámbito local, regional, nacional e internacional), retransmisiones, debates, y magazines. No cuenta con medios técnicos para documentales y grandes musicales.

- La producción ajena se da en ficción, dramáticos, documentales, musicales, dibujos... Busca un equilibrio entre 
criterios de protección a la industria nacional y de rentabilidad. No fomenta las inversiones para producción autóctona.

- La emisión se centraliza exclusivamente en Valencia (Burjassot) con centros de producción en las tres provincias y con una programación de máximo 50 horas a la semana.

- Esta opción se fundamenta en buscar la rentabilidad a corto plazo, introduciéndose pasivamente en el mercado como lo hacen las televisiones privadas italianas que programan durante los horarios de mayor audiencia.

- La ventaja es su sencillez y rapidez de implantación, y la financiación del coste de los servicios por la publicidad. Y los inconvenientes son la dificultad y lentitud con que se incorpora la producción propia y los altos costes de doblaje al valenciano de la producción ajena.

- Modelo B:

- La producción propia se basa en los informativos, retransmisiones, debates, magazines y similares, pero se tienen medios suficientes para realizar una programación concreta.

- Se promueve la producción propia a través de la colaboración con el sector privado o con la creación de empresas mixtas.

- La emisión tendría un techo de 70 horas semanales.

- Este modelo se basa en la maximización del servicio social, cambiando la naturaleza del producto a ofertar con respecto al modelo A.

- Como ventajas se observa la necesidad de un Centro de Producción de Programas, medios consolidados para autofinanciarse y poder cubrir la programación regular de producción propia, y el control y limitación de la compra de producción ajena. 
- Sobre los inconvenientes se tiende a una empresa ajena a TVV, una empresa mixta, con peligro de privatizarse debido a la necesidad de inversión.

- Modelo C:

- La producción propia tiene mucho peso en todo tipo de programas, con fuerte presencia del valenciano. La producción ajena se limita a criterios comerciales, admitiendo coproducciones.

- El máximo de horas semanales sigue siendo de 70.

- El planteamiento central sería el mismo que el B, siendo su modelo de referencia una TVE a menor escala o el modelo de TV3.

- Las ventajas de este modelo, con mucha producción propia, es la autonomía que tiene sobre el sector privado y la producción ajena. Asimismo, se fomenta una organización vertical del proceso de producción, emisión y distribución.

- El mayor inconveniente es el empobrecimiento del sector audiovisual privado autonómico. Además, con la financiación pública necesaria se produciría un gran endeudamiento o déficit a medio-largo plazo.

- Modelo D:

- Este modelo adopta las características de producción propia y ajena del $\mathrm{B}$, pero su estructura de emisión está fraccionada en parte con los centros de producción provinciales.

- El máximo se situaría también en las 70 horas semanales.

- Se fundamenta, a diferencia de las otras en que se sitúan como modelo empresarial, como una cadena regional de televisiones locales con programación fragmentada en parte.

- Su ventaja es que "permite una mayor descentralización del medio, facilita el acceso y atención informativa independiente 
de áreas social y económicamente diferenciadas, posibilita la cooperación económica de las corporaciones locales en la extensión de la red y sus servicios y, en suma, permite un mejor aprovechamiento del tercer canal y una mayor pluralidad".

- Desventajas de esta opción son que "al afectar en lo esencial a la red de emisores y re-emisores exige compatibilizar competencias de la administración central en materia de red con la potestad del Consell para contribuir a su desarrollo, lo cual reabriría una batalla jurídica: no en vano la inclusión del cable en la Ley de Creación de RTVV fue recurrida por el Gobierno central. También exige un incremento de la inversión en la red, condicionando la organización interna de los servicios e incrementando ligeramente a su vez los costes de explotación” (Ibíd.2002:40-47).

Finalmente, el DGMCS se decantó por el modelo B, pero el director general de RTVV, Amadeu Fabregat se decidió por un híbrido entre los modelos A y B.

Con el Real Decreto de 8 de abril 1988 llegó la concesión gubernamental del tercer canal, en mayo el Consell de la Generalitat Valenciana aprobó el anteproyecto de Presupuestos para RTVV que sumaban 2.056 millones de pesetas. Siguiendo la Ley de Creación del Ente Público RTVV, el 9 de marzo de 1988, Les Corts valencianas eligieron por mayoría cualificada los primeros miembros del Consejo de Administración de RTVV con Enrique Linde Paniagua del PSPVPSOE como presidente. Como contemplaba la citada ley 7/1984 y a propuesta del Consejo de Administración, el 5 de abril de 1988 el Consell nombraba a Amadeu Fabregat Mañes como director general del ente público (Ibíd. 2002:50,51).

El 9 de octubre de 1989, coincidiendo con el Día de la Comunidad Valenciana, Canal 9 realizó su primera emisión en todo el territorio autonómico, algunas zonas de la provincia de Tarragona, Baleares, Murcia, este de Castilla-La Mancha y áreas próximas de Teruel. El 11 de agosto de 2008 también emitió a través de la Televisión Digital Terrestre (TDT) en Cataluña, donde pudo verse el canal internacional de RTVV hasta 2010. 


\section{cronología HISTórIca DE RTVV}

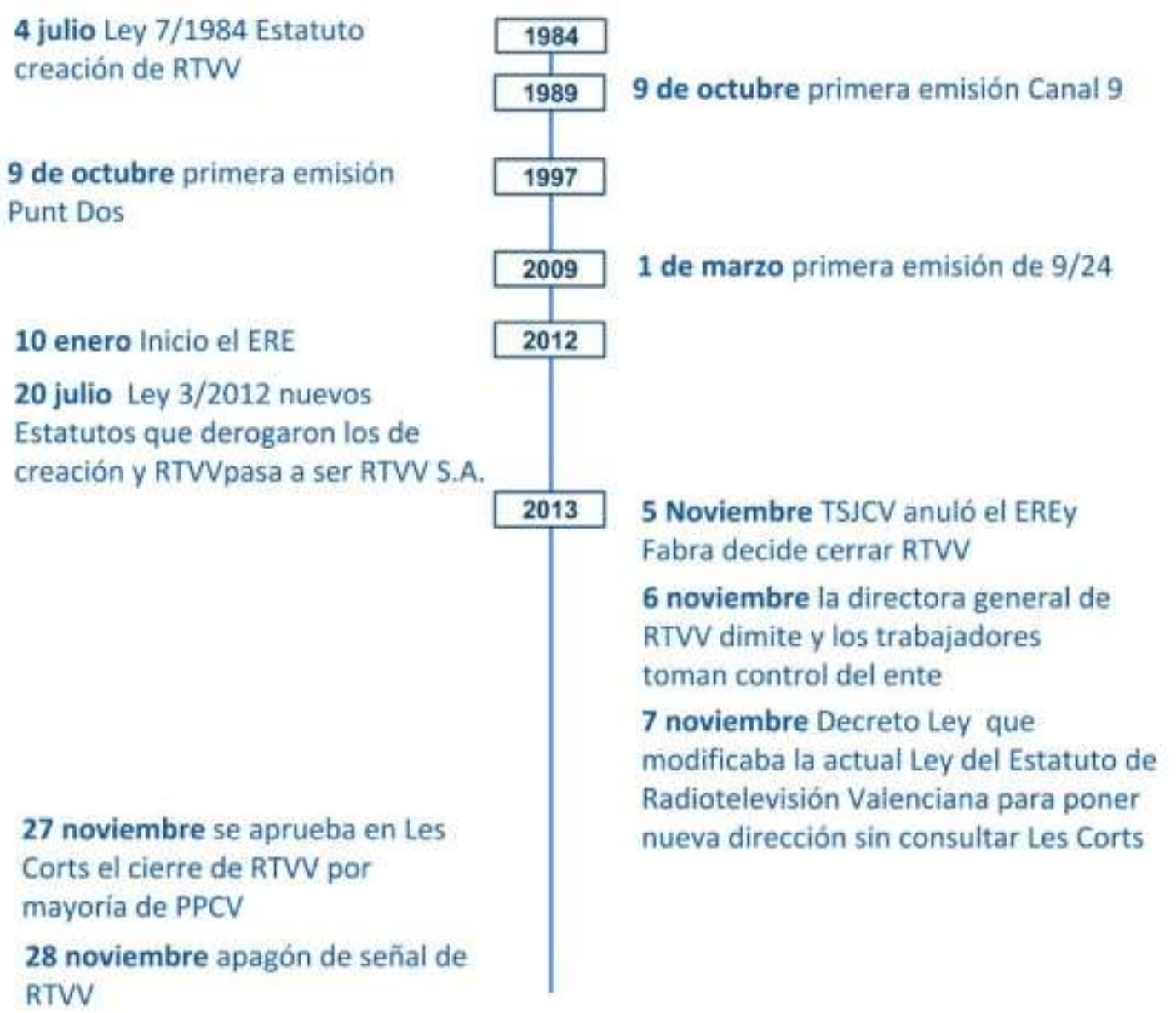

Elaboración propia.

Ilustración 12. Cronología histórica de RTVV

En la Comunidad Valenciana, dejó de emitirse la señal de la televisión pública catalana TV3 por motivos políticos, pues para algunos sectores valencianos la televisión catalana se escapaba al control de la Generalitat Valenciana. El grupo ciudadano de la Comunidad Valenciana 'Acción Cultural' decidió en 1986 instalar repetidores para ver la TV3, pues la Comunidad Valenciana carecía de televisión autonómica propia en esos momentos. Con la llegada de ésta en 1989, los repetidores continuaron conviviendo con RTVV hasta que en 2006 la Generalitat modificó la Ley audiovisual valenciana, obligando con multas y demandas a que la plataforma ciudadana fuese apagando los repetidores. Finalmente, el 17 de febrero de 2011 
se apagó el último de ellos dejando a la Comunidad Valenciana sin la señal de TV3.

RTVV estaba compuesta por la cadena principal del ente Canal 9 en la que se combinaba el castellano con el valenciano, la producción propia y la ajena y era la que contaba con el mayor presupuesto. La segunda cadena Nou 2, emitía por primera vez el 9 de octubre de 1997 bajo el nombre de Punt Dos. En ella destacaba la producción propia y se emitía íntegramente en valenciano. La programación infantil, los documentales, el deporte y la cultura valenciana eran sus ejes de programación. El 30 de marzo de 2009 pasó a emitir en digital (Televisión Digital Terrestre, TDT) y cedió su señal analógica al nuevo canal del ente, Nou 24.

Finalmente, Nou 24 fue el tercer canal de la corporación autonómica, comenzó sus emisiones el 1 de marzo de 2009 denominándose 9/24, pero en 2010 adoptó el de Nou 24. Se distinguía por su contenido informativo. Realizaban mini informativos cada media hora y repetían los informativos de Nou 2 en diferido. También incluían pequeñas entrevistas y reportajes en profundidad.

Como todas las televisiones autonómicas, Canal 9 siguió el modelo de TVE, incluso en la financiación mixta. Si bien es cierto, optó por una programación muy agresiva y comercial, con una calidad de producción propia baja, y emitía la totalidad de su ficción en castellano. Aunque para la ex presidenta del Consejo de Informativos de TVE, Yolanda Sobero, "las televisiones autonómicas se crearon siguiendo el peor modelo de lo que era esta casa, se reprodujo lo malo y a veces con ninguna de las virtudes, que alguna habría".

Por este motivo las quejas comenzaron a tomar fuerza, fundamentadas en el incumplimiento del Estatuto de creación del ente, por la falta de fomento de la lengua autonómica, inexistente en el 'prime time', y por los conflictos con los actores de doblaje y empresas audiovisuales valencianas.

Con la llegada de las televisiones privadas nacionales, Canal 9 pasa al cuarto puesto de las televisiones más vistas en la comunidad, y en este ranking de audiencia permanecerá hasta el final salvo algún periodo de excepción. 
Desde que el Partido Popular (PP) se hiciera con el poder de la Generalitat en 1995, RTVV fue el foco de numerosas críticas parlamentarias y sociales por su falta de independencia política, su gestión económica, de recursos humanos y su pésima programación.

Su imagen quedó determinada por los escándalos causados por la falta de transparencia económica, y los beneficios que el ente dio a empresas ligadas al $\mathrm{PPCV}^{62}$. RTVV se vio sumida en una inestabilidad que se materializó en los cuatro directores generales que tuvo en algo más de tres años (Xambó, 2010:13).

Desde distintos sectores de la sociedad valenciana se consideraba que el modelo de RTVV necesitaba un cambio acorde con las necesidades sociales, culturales, económicas y políticas de la Comunidad Valenciana. Para ello, según el socio-lingüista valenciano, Toni Mollà (2010), Les Corts deberían haberse implicado y plantear una estrategia y una legislación audiovisual nueva, incluyendo la creación del Consejo Audiovisual Valenciano, una Ley Audiovisual y la reforma del régimen jurídico del ente público. Para Mollà, con estas transformaciones se deberían haber ampliado las miras con el propósito de cumplir con la legislación europea, definir claramente la noción de servicio público y garantizar el desarrollo de la sociedad digital.

La instauración de nuevos operadores y tecnologías, obligaban a RTVV a realizar cambios para devolverla a la realidad del sector audiovisual, tanto a nivel nacional como europeo. Pero para renovarlo Mollà no pensaba que la privatización ni directa (con el cambio de la titularidad y accionistas), ni indirecta (con la gestión de contenidos, ingresos, etc.) fuera la solución, pues condicionaría el desarrollo del medio público.

Para este autor, la renovación debía devolver la legitimidad social a RTVV, democratizando la corporación, mediante una programación

\footnotetext{
${ }^{62}$ Entre otras la concesión de licencias televisivas con la implantación del TDT. De las 14 demarcaciones 13 fueron para Mediamed, empresa creada con el fin de presentarse al concurso y cuyo accionista mayoritario está implicado en la trama Gürtel (Xambó, 2010:13). Como el caso de Tele Elx que quedó fuera de dichas licencias y que, tras interponer la correspondiente denuncia, finalmente el Tribunal Supremo ha dado la razón a la televisión local ilicitana.
} 
de calidad que representara y cubriera las necesidades de toda la sociedad de la Comunidad Valenciana. Pues la televisión pública es la garantía para "fomentar los principios y valores que no pueden ser garantizados nada más a partir del mercado". En consecuencia, el camino a seguir lo marcaban las directrices comunitarias que mostraban las claves para mantener un sector público fuerte, que no pueda ser sustituido en sus funciones como garante de pluralismo, formación, entretenimiento y de acceso igualitario. En el caso de RTVV que fuera el motor del sector audiovisual valenciano (Mollà, 2010:66).

Sin embargo, todas estas teorías de cambio no fueron puestas en práctica y definitivamente en agosto de 2012, ante la ruina financiera del ente, el Consell y la dirección de RTVV comenzaron a ejecutar un ERE que, en opinión de estas instituciones, era la única solución posible para salvar RTVV. Con los primeros despidos, las reemisiones de programas antiguos ocupaban el 98\% a la parrilla semanal en Canal 9, que mantenía solamente la producción de cinco programas: Ocupa't, Futbolistes, Societat Anònima, De festa en festa y Babalà. Llegando a reponer algunas películas hasta una veintena de veces $^{63}$.

Sin embargo, según el ex jefe de Gabinete de Alarte (PSPV), Josep Moreno ${ }^{64}$, "el PPCV soñaba con una privatización en la que ellos gestionaran sólo los servicios informativos". Incluso, había otras posibles soluciones que no se contemplaron. Según el Consejo de Informativos de TVE, se podría hacer extensible la Ley de Radiotelevisión Estatal a todas las autonómicas, puesto que también son públicas. Esta medida también tendría una incógnita preocupante: que los políticos tuvieran "la tentación de cambiar la Ley audiovisual, y ya que están, dejar que se privatice o haya una gestión privada de las televisiones autonómicas, etc.", apuntaba

${ }^{63}$ Noticia consultada el 12-05-2013 en http://ccaa.elpais.com/ccaa/2013/02/28/valencia/1362084404 467005.html ${ }^{64}$ Entrevista personal realizada en las dependencias del grupo parlamentario de PSPV en Les Corts en Valencia, el 14-06-2011. 
Yolanda Sobero, ex presidenta del Consejo de Informativos de $\mathrm{TVE}^{65}$.

El siguiente paso fue la aprobación en julio de 2012 de unos nuevos estatutos (Ley 3/2012) que derogaban la Ley 7/1984 de creación de RTVV. Con esta nueva ordenanza el ente RTVV pasaba a ser RTVV S.A., una sociedad mercantil de titularidad pública con especial autonomía. En el nuevo estatuto, que se verificaría cada nueve años, se estipulaba la creación de un contrato programa que debía revisarse cada tres años por el Consell y RTVV S.A. Además, se estableció una financiación mixta (pública ${ }^{66}$ y privada), que diferenciaba el contenido de servicio público del que no lo era. Aunque este fue uno de los puntos más controvertidos por la dificultad a la hora de determinar dichos términos. Otro punto importante del contrato, era la limitación del gasto público en 69.5 millones de euros por año.

El modelo mixto parece ser la tendencia imperante en las televisiones públicas europeas. Según Campos-Freire (2013):

"El futuro de la televisión y el audiovisual europeo es híbrido, convergente, conectado, interactivo y cada vez más de pago. (...) En esta década las grandes preocupaciones son: lograr mantener la financiación suficiente para garantizar su viabilidad, tratar de estar presente en todas las plataformas posibles de difusión y sobre todo en Internet, avanzar y acertar en los procesos de reestructuración sin dañar los principios generales de servicio público de calidad y lograr mantener la credibilidad a través de la mejora de la gobernanza $^{67}$

\footnotetext{
${ }^{65}$ Entrevista realizada en 2011 para la tesis doctoral "Pluralismo político en los programas informativos de Canal 9 y La 1 (TVE) durante las elecciones autonómicas y generales de 2011" defendida el 20 de diciembre de 2012 en la Universidad Miguel Hernández de Elche, Alicante.

${ }^{66}$ Para el contenido de servicio público

${ }^{67}$ En 2012, el Consejo de la Asamblea Parlamentaria de Europa, mostró su apoyo a la Unión Europea de Radiodifusión (UER) para contrarrestar la incursión política en la gestión de la televisión pública en Hungría, Bosnia, Croacia, Italia, Rumania, Eslovaquia, Serbia, España y Ucrania (Ibid., 2013).
} 
Otro de los aspectos más destacables aparecía en el artículo 15 del Estatuto, que hacía referencia a la responsabilidad de los administradores. Los consejeros lo calificaron como "positivo", pues pensaban que podría evitar excesos por parte de los administradores que nombrara el Consejo.

A pesar de ello los administradores no podían ser sometidos "a instrucción", pero al tratarse de una entidad privada supeditada a la Ley de Sociedades de Capital, sí tenían una "responsabilidad solidaria" si la institución hubiera sido condenada en algún momento.

En referencia al nuevo contrato programa de RTVV S.A. poseía cuatro bloques diferenciados:

I. Establecer los objetivos y compromisos de programación distinguiendo aquellos que son propios de servicio público de los que no los son.

II. Definir las líneas estratégicas de contenidos, emisión y producción.

III. Establecer el modelo de financiación de Radiotelevisión Valenciana.

IV. Fijar los medios para el control de objetivos establecidos en el mismo.

Una de las cuestiones más controvertidas fue el uso del valenciano, que quedaba blindado en los informativos según el artículo 6.2.6, y que estaba asegurado sólo en un $20 \%$ de la programación según el Estatuto (Ley 13/2012).

Por otro lado, definía el modelo para elegir al director general de RTVV S.A. que se decidiría con el voto de dos tercios en Les Corts, aunque podría hacerse en segunda vuelta por mayoría simple. Es decir, por el mismo sistema que se realiza en RTVE desde al cambio legislativo que realizó el PP en 2012.

El contrato permitía: 
"la comercialización y venta, así como la cesión a terceros, de producciones y programas de radio y televisión, tanto propios como ajenos (...) y los espacios para publicidad mediante anuncios, patrocinios, sobreimpresiones y por cualquier otro procedimiento".

Igualmente, estaba admitida:

"la producción de obras y grabaciones audiovisuales, para uso propio o de terceros, así como su comercialización, distribución alquiler y venta".

También se preveía:

"la adquisición, mantenimiento y explotación por cuenta propia o ajena, bien para uso propio o de terceros, de equipos, aparatos, elementos, instalaciones y procedimientos técnicos relacionados con las actividades propias de su objeto social, incluyendo los vinculados a la red de difusión, así como licencias de patentes o asistencia tecnológica, la distribución de productos informáticos".

Teniendo en cuenta que desde la Generalitat se contemplaba la idea de privatizar franjas horarias, incluso de pagar a una empresa externa para que las gestionara, cabe pensar que esta normativa facilitaba situaciones muy ventajosas para las empresas privadas.

Por ejemplo, este contrato permitía que se adquiriese un programa con dinero público para que posteriormente lo explotara una empresa privada, o que RTVV S.A. comprara la producción a una compañía externa (que utilizara los recursos técnicos del ente público) y a continuación, fuera cedida de nuevo a la empresa privada para que explotara una de las franjas horarias externalizadas (Ley 13/2012).

El contrato programa establecía unos mínimos porcentuales de distintos tipos de programas, que debían formar parte de la programación de RTVV para garantizar la prestación de servicio público de la corporación. 
porcentajes minimos de emision por

TIPOlogía de programas de servicio PÜBLICO

Informativos

Divulgativos/Culturales

Entretenimiento

Infantil/Juvenil

Deportivos

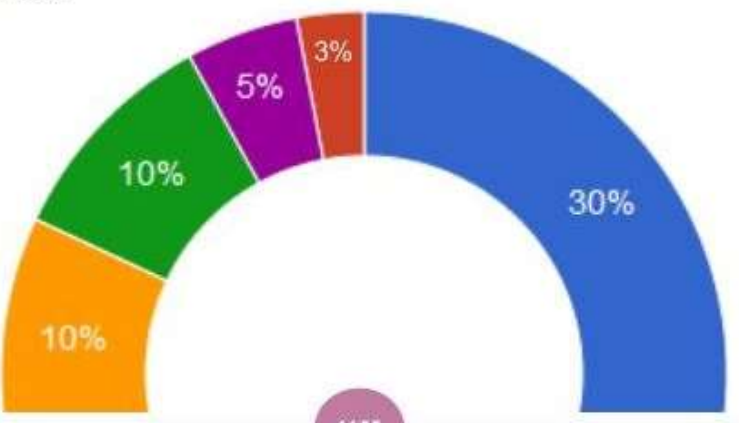

(43)

Según el Contrato Programa debían formar parte de la programación de RTV para garantizar la prestación de servicio público

Elaboración propia. Contrato programa RTVV 2013.

Ilustración 13. Proporción ideal de tipos de programas en la parrilla de RTVV

A pesar de que el ERE era la única opción que contemplaba la Generalitat como solución al déficit de RTVV, el Gobierno del PPCV no explicaba los motivos de dicho agujero en las cuentas de la televisión pública: los desorbitados despilfarros de la dirección.

Específicamente se gastaron 7,4 millones de euros en comidas, taxis y gasolina durante cinco años, sólo en 2012 fueron 750 mil euros. Según la Sindicatura de Comptes, algunos de estos gastos "justificados carecen de los requisitos necesarios para comprobar su adecuada finalidad, ya que en las facturas no se indica ni el número de comensales, ni el motivo de la comida o viaje" ${ }^{68}$. Aunque en 2008 los gastos superaban los dos millones de euros, con el comienzo de la crisis se fueron reduciendo, si bien continuaban siendo desproporcionados a juicio de la Sindicatura, dejando patente el uso ineficiente que se hacía del dinero público en RTVV.

${ }^{68}$ Noticia consultada el 29-12-2013 en

http://www.lasprovincias.es/v/20131224/politica/rtvv-gastomillones-taxis20131224.html 
Uno de los últimos excesos que se permitió Canal 9, fue la retransmisión de dos temporadas de la Fórmula 1 que supusieron un gasto de 10 millones cada una. Para su cobertura se contrató al locutor Víctor Seara, quien recibió 10.000 euros al mes. Por este asunto están imputados el ex president de la Generalitat Francisco Camps, la ex consellera Lola Johnson y el ex piloto y empresario Jorge Martínez Aspar ${ }^{69}$.

Envuelto en el caso de corrupción Gürtel, se encuentra además la visita del Papa a Valencia el año 2006 que, dejando al margen la contratación externa de los equipos de sonido y los equipos de imagen, se desembolsaron 6,4 millones de euros.

Posteriormente, incluso se conoció que los costes de los contratos de Canal 9 con los equipos valencianos de fútbol de Primera División, se dispararon hasta los 460 millones de euros. La televisión pública pagó por los derechos del Valencia CF, Villarreal CF, UD Levante y hasta financió sus mascotas.

Entre los ejemplos de honorarios más ofensivos, estuvo el del periodista Jesús Mariñas, que por cada participación semanal en el sensacionalista programa del corazón 'Tómbola' percibía 3.000 euros.

Otro conocido periodista, Julián Lago, conducía el programa 'Panorama de actualidad' que suponía 150.000 euros por programa, y las remuneraciones eran 21.000 euros para el director y 3.000 para cada invitado. El programa tenía un 1\% de audiencia.

Entre los nombres conocidos se encuentra Fernando Sánchez Dragó, quien presentaba el programa 'El Faro de Alejandría', que significaba un coste de 55.000 euros por cada emisión. O los salarios en las tertulias nocturnas, que llegaban a 800 euros por participante cada noche.

Canal 9 también llegó a sufragar tres documentales 50 veces por encima de su precio de mercado. 200.000 euros. Éstos poseían una intencionalidad política como por ejemplo 'Garzón, el juez estrella al

${ }^{69}$ Noticia consultada el 20-03-2016 en http://www.elperiodicomediterraneo.com/noticias/comunitat/apuntangerardo-camps-pago-formula-1 982132.html 
descubierto', de la productora Triskel Audiovisual, por el que se abonaron 66.000 euros, mientras que otras emisoras pagaban entre 1.000 y 1.500 euros.

Cuestión aparte, serían las retribuciones que llegaron a cobrar los directivos de RTVV, muchos de ellos por encima de los presidentes de la Generalitat y del Gobierno de España. El Director General, José López Jaraba, cobraba en 2009 un total de 83.302 euros anuales (un 25\% más que Francisco Camps y un 15\% más que José Luis Rodríguez Zapatero, en aquel momento), además de 21.600 euros anuales por dietas.

Lola Johnson, antes de ser Consellera de Cultura de Camps, fue directora de Canal 9, cargo por el que llegó a percibir 80.417 euros anuales. Por su parte, Lluís Motes, recibía 64.404 euros al año cuando dirigía Ràdio $9^{70}$.

El ERE de RTVV iba a afectar a un total de 1.198 trabajadores del ente público. Pero en agosto de 2013 la nueva directora general, Rosa Vidal, mantuvo en la empresa a 186 técnicos que debían incluirse en el ERE para garantizar el funcionamiento de la empresa. Por lo que la plantilla de RTVV contaba finalmente con 678 profesionales (en lugar de 480 trabajadores, como estaba previsto inicialmente). Esta decisión contrarió al Consell y sobre todo a José Ciscar, portavoz del mismo, quién formó parte del ERE, al que defendió como algo inexorable y necesario, sin posibilidad de ningún tipo de revisión. Posteriormente, Ciscar dejó claro a Vidal que el presupuesto con el que contaría según el contrato programa sería el mismo y que debería asumir los siete millones de euros que suponen los salarios de esos 186 técnicos que habían sido rescatados del ERE.

Las protestas fueron numerosas, incluso un grupo de empleados irrumpió en el estudio 3 el 16 de julio de 2012, paró el informativo del mediodía y lanzó sus mensajes contra la dirección y la política de despidos hasta que la emisión fue cortada, siendo expedientados por la empresa.

\footnotetext{
${ }^{70}$ Noticia consultada el 12-05-2014 en http://www.eldiario.es/cv/rtvv/saqueadoresCanal 0 194230813.html
} 


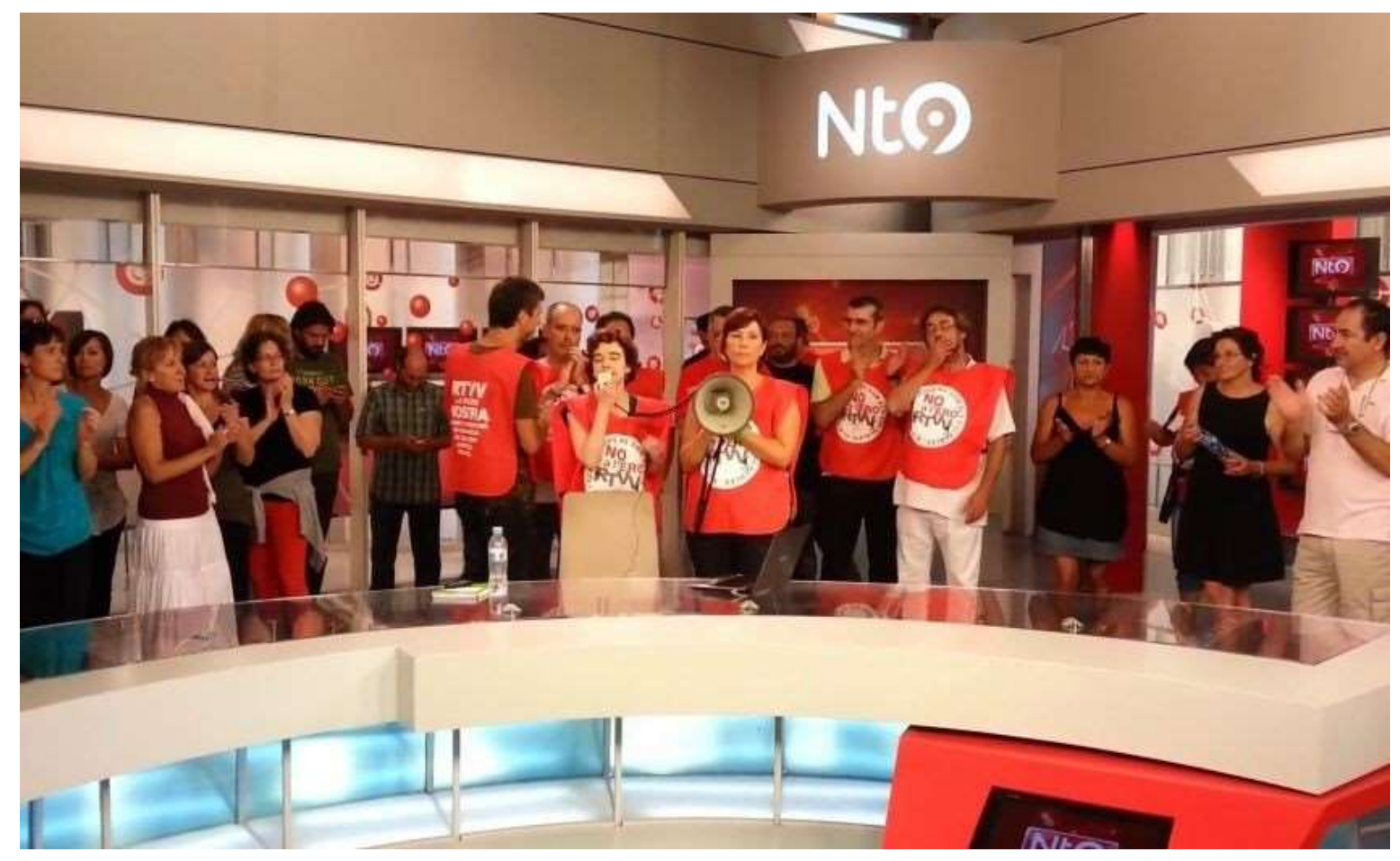

Ilustración 14. Imagen de los trabajadores de RTVV tomando el plató en directo $^{71}$

Los sindicatos (Intersindical, UGT, CCOO, CGT, USO y CSI $\cdot$ F) denunciaron ante el Tribunal Superior de la Comunidad Valenciana y el Tribunal Constitucional dicho ERE basándose en supuestas irregularidades tales como $^{72}$ :

1. Nombramiento irregular del nuevo director general de RTVV. Pues tras la dimisión de López Jaraba, su sucesor, Alejandro Reig, no fue elegido por el Consejo de Administración como dictan los estatutos sino por el Consell, por lo que los despidos firmados por Reig podrían ser anulados judicialmente.

2. Comunicación progresiva y no conjunta de los despidos a los trabajadores afectados. Pues según el artículo 51.4 del Estatuto

\footnotetext{
${ }^{71}$ Imagen recogida el 15-02-2014 en http://www.elplural.com/wpcontent/uploads/Los-trabajadores-deCanal-Nou-toman-un-plat $\%$ C3\%B3-enla- $\%$ C3\%A9poca-en-que-se-estaba-produciendo-el-ERE.jpg

${ }^{72}$ Noticia consultada el 18-11-2013 en http://www.valenciaplaza.com/ver/70776/las-prisas-por-ejecutar-elere-dertvv-tras-cuatro-meses-parado-ponen-en-riesgo-su-legalidad.html
} 
de los Trabajadores y la Sentencia del Tribunal Superior de Justicia de Cataluña (Sala de lo Social) número 13/2012 del 23 de mayo de 2012, se debe informar a los trabajadores de forma individual.

3. Uso de información relativa a la salud de los trabajadores como criterio de despido. En este caso se estaría vulnerando el artículo 43 de la Constitución (Derecho a la salud) y de la Ley 14/1986 de 25 de abril General de la Sanidad. Para ello solicitaban detalles sobre las bajas médicas prolongada por enfermedad profesional, común, grave o crónica durante los últimos tres años.

4. Diferencias entre las empresas de RTVV en cuanto a la valoración de la oposición como método para formar parte de la corporación. Para los trabajadores de la Ràdio Autonòmica Valenciana (RAV) y Televisió Valenciana (TVV), este criterio era el octavo a la hora de seleccionar a un trabajador para el despido, mientras que para RTVV era el primero. En este caso los profesionales de TVV y RAV que aprobaron unas oposiciones estaban siendo perjudicados con respecto a los trabajadores de RTVV, para los que tenían muy en cuenta si eran funcionarios o no para incluirlos en el ERE.

5. No existía una justificación económica de los despidos puesto que, aunque la ley defiende la posibilidad de despidos en caso de inviabilidad económica, no tiene sentido externalizar los servicios que sus propios trabajadores realizan.

6. Vulneración del convenio colectivo vigente con respecto a la indemnización de 45 días por año para los trabajadores despedidos. A pesar de que la dirección de RTVV justifica la reducción de la indemnización a 20 días por año en el artículo 26.3 de la Ley 10/2011 (Presupuestos de la Generalidad Valenciana para el año 2012), las demandas colectivas alegan que esta norma se deberá aplicar a los pactos, acuerdos y convenios firmados con posterioridad a la aprobación de la ley y no a los anteriores. Este es el caso del convenio actual de RTVV, que prorroga el de 2008. 
7. Falta de voluntad de negociación por parte de la dirección de RTVV. Según los sindicados la negociación debía haberse prolongado hasta el 23 de agosto de 2012, pero la dirección la finalizó el viernes 17 de agosto.

8. Contrariedad entre la presentación del ERE y el cumplimiento de la nueva ley de RTVV respecto a su financiación pública. El expediente de regulación de empleo se fijó antes de que se elaborara el contrato programa y se asignara la correspondiente cifra de dinero público con la que contaría anualmente la corporación valenciana.

Un año después del inicio del ERE, el proceso seguía pendiente del Tribunal Superior de Justicia de la Comunidad Valenciana (TSJCV) que debía concluir si el expediente de regulación convenía ser impugnado o no. El 9 de septiembre de 2013, la abogacía de la Generalitat Valenciana se pronunció alegando que en el caso de que el ERE fuera anulado, el contrato programa de RTVV debía permanecer vigente por la importancia del ente como servicio público.

Los representantes de la oposición en el Consejo de Administración de RTVV S.A. resaltaban la arbitrariedad con la que se llevó a cabo el ERE, que afectó al $75 \%$ de la plantilla, por tanto, esperaban la nulidad del mismo por parte del Tribunal Superior de la Comunidad Valenciana.

Finalmente así ocurrió, el 5 de noviembre de 2013 el TSJCV anuló el ERE, desencadenando una serie de acontecimientos de gran transcendencia para la sociedad valenciana.

Tras esta sentencia el presidente de la Generalitat, Alberto Fabra, afirmó que cerraría la televisión pública de forma "inmediata e irrevocable". Después de estas declaraciones la directora general de RTVV S.A. Rosa Vidal y los cuatro consejeros del PPCV en el ente dimitieron, dejando a la empresa sin dirección.

En consecuencia, los propios trabajadores de RTVV asumieron la dirección realizando su propia programación y denunciando los abusos del PPCV a los que se habían visto sometidos durante, al 
menos, la última década. Esto supuso triplicar la audiencia de Canal 9, pues comenzaron a hacerse programas informativos veraces, sin censura, con unos trabajadores que estaban disfrutando de la libertad de expresión que se les había negado hasta entonces.

En noviembre de 2013 los propios profesionales pidieron perdón a las víctimas del accidente de metro en Valencia y a toda la audiencia, por el tratamiento informativo que realizaron. Aunque Canal 9 fue el primero en cubrir el accidente y sus imágenes fueron utilizadas en todas las televisiones en España,

"el problema vino después: las consecuencias, las voces que se silenciaron, la investigación del accidente y también el trasfondo político que hemos podido escuchar en otros medios. Canal 9 tuvo una actitud indigna para una televisión pública que debería haber estado al lado de sus ciudadanos.

Las órdenes para silenciar aquellas voces, para no entrar en la investigación, para callar muchas situaciones, salieron de un despacho, del despacho del Palacio de la Generalitat. Del mismo despacho que ayer salió otra orden: retirarnos estos micrófonos y estas cámaras y no poder mantenerles a todos ustedes informados de lo que está pasando"73

La propia ex-directora general, Rosa Vidal, declaró públicamente que recibió presiones tanto en la gestión de la empresa, como en los informativos, pero que se negaron a acatarlas, por lo que empezaron a tener problemas con la Generalitat. Igualmente, relató que la Generalitat había mentido en el comunicado que realizó para anunciar el cierre de RTVV, puesto que con sólo siete meses de gestión "íbamos a cerrar el año con beneficios, algo que no han tenido en 24 años" en el ente público. Asimismo, detalló como no recibió un traspaso de poderes, y como encontró la empresa sumida en un caos de desgobierno, donde los ordenadores "estaban limpios", no había nada.

\footnotetext{
${ }^{73}$ Video consultado el 20-02-2014 en http://www.eldiario.es/rastreador/VIDEO-Canal-silenciaraccidenteValencia 6 194290590.html
} 


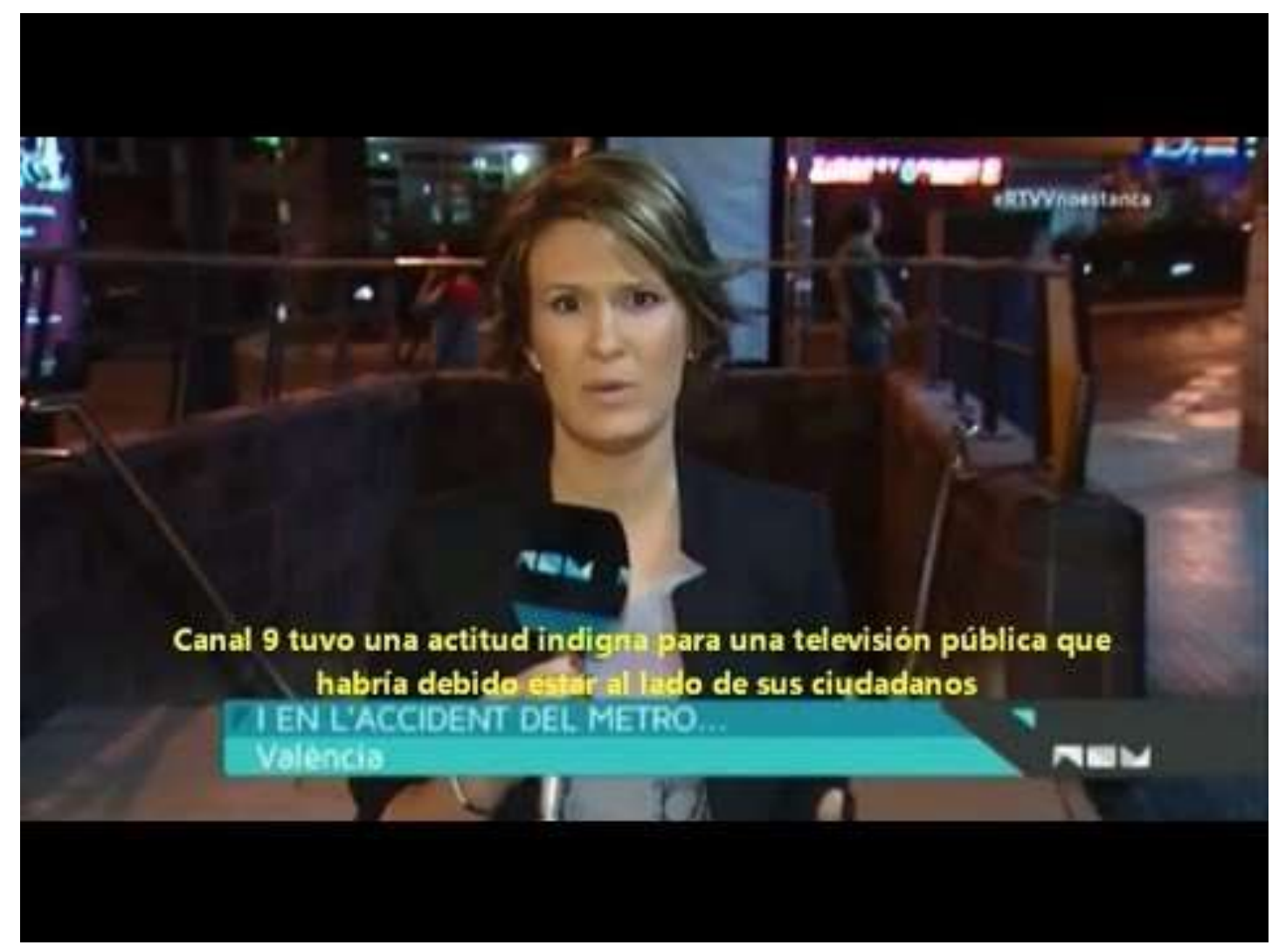

Ilustración 15. Imagen de los profesionales de RTVV pidiendo perdón por el tratamiento informativo del accidente del metro en Valencia ${ }^{74}$.

Sin embargo, desde la Generalitat intentaron frenar el control de los trabajadores sobre la televisión a través de un Decreto Ley que modificaba la actual Ley del Estatuto de Radiotelevisión Valenciana. Según José Císcar, la modificación de la ley estaba justificada en la "ingobernabilidad" y "prestación anormal del servicio".

Este Decreto, publicado en el DOCV el 7 de noviembre de 2013, incorporaba un nuevo apartado que permitía el nombramiento del director general y de los consejeros sin pasar por Les Corts alegando que:

"En aquellos supuestos en los que como consecuencia del cese, destitución o renuncia de sus miembros, el consejo de administración no pueda alcanzar el quórum necesario para adoptar acuerdos, se habilita a la Junta General para que nombre provisionalmente a todos los cargos vacantes, incluido en su caso el director o directora general, hasta la

\footnotetext{
${ }^{74}$ Imagen recuperada el 10-03-2016 en https://i.ytimg.com/vi/VdmKreM11 A0/hqdefault.jpg 
constitución de un nuevo consejo de administración elegido por Les Corts de acuerdo con el procedimiento ordinario previsto en el Artículo 13 de esta Ley"

Como consecuencia, la Generalitat nombró a Ernesto Moreno como director general de RTVV y a José Serralde, Bartolomé Orozco, Luis Bertomeu y Vicente Burgos como consejeros, en un intento de hacerse con el control de la televisión valenciana hasta que se ejecutara el cierre y liquidación de la misma, que corrió a cuenta de la Generalitat Valenciana y el propio Ernesto Moreno. La liquidación de RTVV se cifró en principio en 70 millones de euros, según el vicepresidente del Consell, José Ciscar.

Por otra parte, cumplir la sentencia del TSJCV suponía a los contribuyentes valencianos 228 millones de euros. Por este motivo, para Ciscar el cierre era la única solución, pues la readmisión de los trabajadores afectados por el ERE y el funcionamiento de la cadena, significaban un gasto de 114 millones de euros, cuando el presupuesto para ese año se limitaba a 61 millones de euros.

El 9 de noviembre de 2013 se realizaron manifestaciones contra el cierre de RTVV en Alicante, Valencia y Castellón respaldadas por miles de ciudadanos y con el apoyo de más de 160 asociaciones educativas, audiovisuales, culturales, etc. así como los comités de empresa de otras televisiones autonómicas (TV3, Canal Sur, Telemadrid, TVG, IB3, CMTV, RTPA y RTVE), de la Unió de Periodistes Valencians y la Federación de Asociaciones de la Prensa de España (FAPE).

Desde la Generalitat no descartaron pedir responsabilidades a los ex directivos de la cadena pública puesto que, en el propio Estatuto, vigente hasta el momento, establecía que los administradores tendrán una "responsabilidad solidaria" aunque no podrán ser llamados a la instrucción en una causa judicial.

No obstante, tras las presiones sociales, la Generalitat dijo que estudiaría la propuesta del Comité de RTVV S.A. Pues las protestas no sólo fueron de colectivos de la Comunidad Valenciana, sino a nivel nacional. Como el discurso de Jordi Évole al recoger su Ondas 
por el programa Salvados sobre el accidente de metro en Valencia, donde afirmó:

"Canal 9, esa televisión que por culpa del poder político, se ha convertido en una caricatura grotesca de lo que es una televisión pública”

La vuelta de los 952 trabajadores despedidos irregularmente por el ERE, también suscitó polémica, porque la readmisión se hizo por email, del mismo modo que fueron despedidos ${ }^{75}$.

Aunque el vicepresidente del Consell, José Ciscar, afirmó que tendrían en consideración las propuestas que el Comité de Empresa de $\mathrm{RTVV}^{76}$ les hizo como alternativa al cierre, finalmente la Generalitat no revocó el cierre de la televisión pública valenciana.

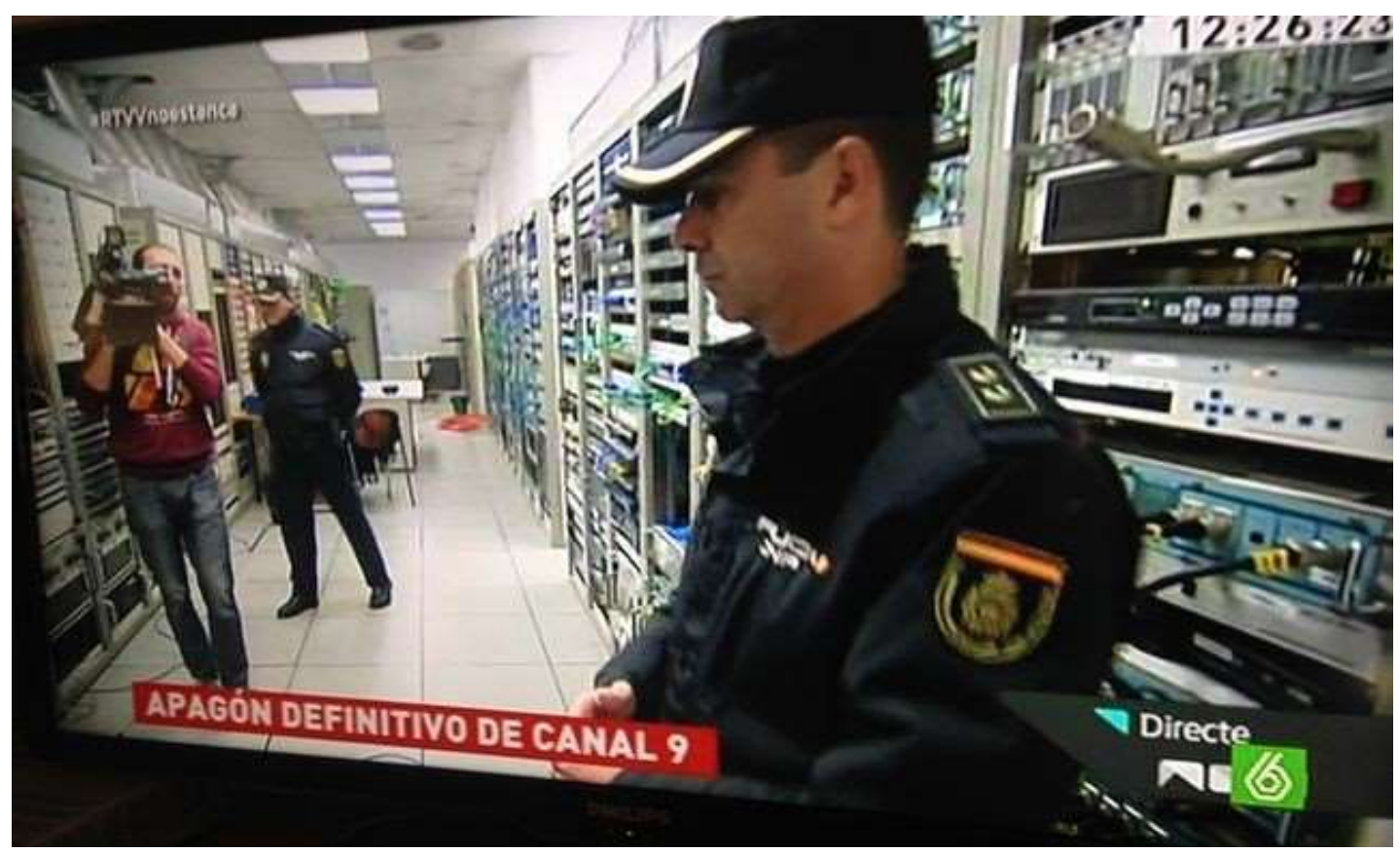

Ilustración 16. Imagen del momento en que la Policía entra a cerrar RTVV mientras se emite la imagen en directo. ${ }^{77}$

${ }^{75}$ Noticia consultada el 22-11-2013 en http://www.elmundo.es/comunidadvalenciana/2013/11/22/528fb47e61fd3d8 2778b4570.html

${ }^{76}$ Noticia consultada el 16-12-2013 en http://ccaa.elpais.com/ccaa/2013/11/22/valencia/1385123919 058661.html ${ }^{77}$ Imagen recogida el 15-03-2014 en http://images.eldiario.es/cv/rtvv/policiavela-cierre-emisionCanal EDIIMA20131129 0229 5.jpg 
El 27 de noviembre de 2013 quedó aprobado en Les Corts valencianas el cierre de RTVV S.A. mediante una Ley ratificada exclusivamente por la mayoría del PPCV y que entró en vigor el 28 de noviembre. Esa misma noche comenzó a hacerse efectivo el cierre del ente público con el apagón de Radio Nou primero y con Canal 9 a las 12.19 horas, después de que la Policía rodeara el edificio y acompañando a un técnico enviado por el Poder Judicial, procedieran a la desconexión de la señal.

Los trabajadores resistieron durante 12 horas con una programación en directo que informaba de los hechos, a la vez que denunciaba el cierre de la televisión pública ${ }^{78}$. El Gobierno valenciano amenazó con penas de prisión a aquellos que opusieran resistencia al cumplimiento de la Ley. Por ello los miembros del Comité de Empresa, no quisieron incurrir en un delito de desobediencia, para poder ser causa del proceso judicial que emprendieron posteriormente ante el Tribunal Constitucional.

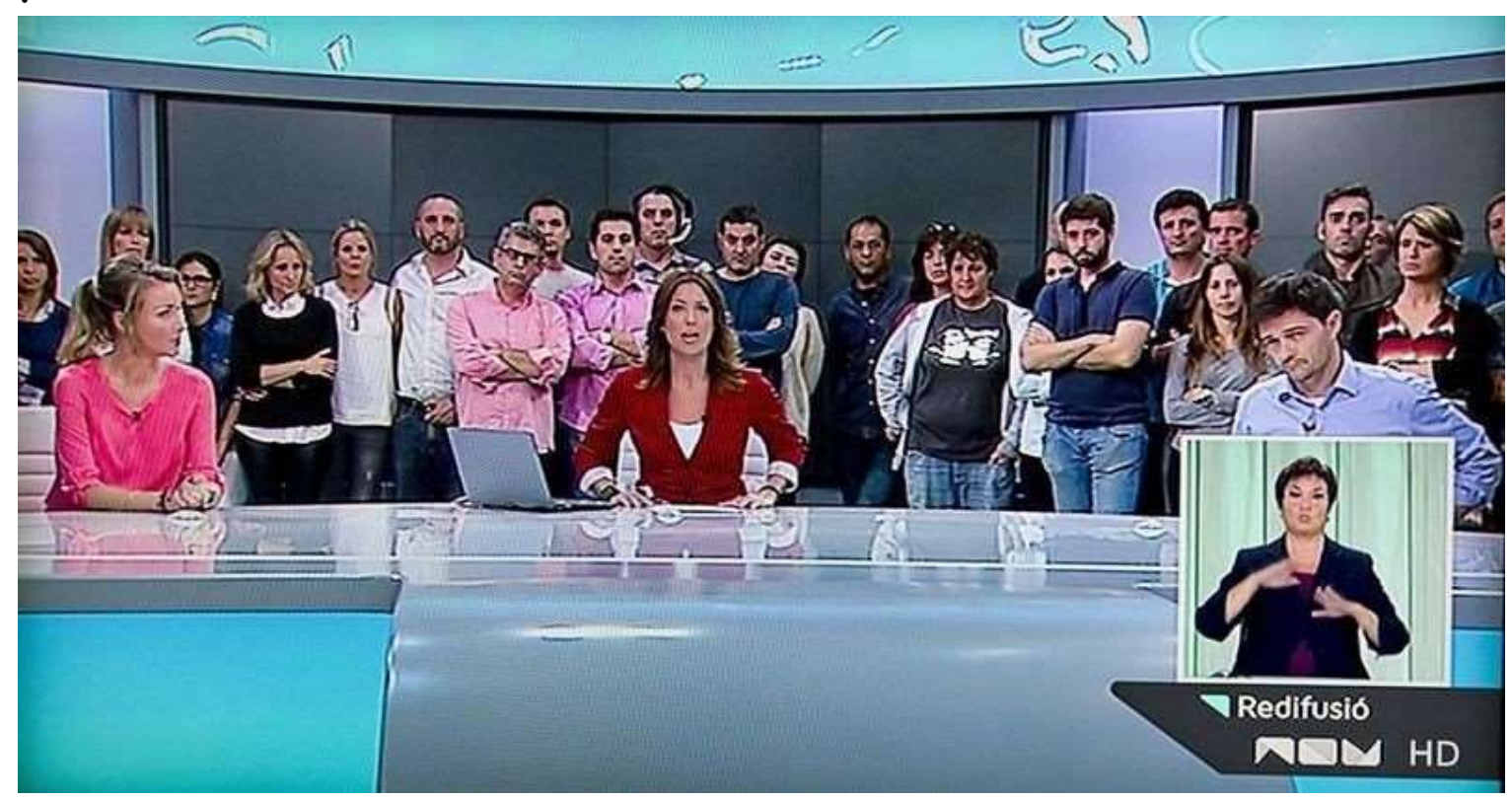

Ilustración 17. Imagen de los profesionales de RTVV en los últimos momentos de emisión. ${ }^{79}$

\footnotetext{
${ }^{78}$ Noticia consultada el 30-11-13 en http://www.eldiario.es/cv/rtvv/CanalRTVV-ordenado-nocturnidadFabra 0 201929827.html

${ }^{79}$ Imagen recogida el 15-03-2014 en http://s.libertaddigital.com/fotos/noticias/trabajadores-platocierre.jpg
} 
Desde el anuncio del presidente de la Generalitat del cierre de RTVV, se consideró la posibilidad de que el Gobierno del PPCV buscase el cierre premeditado de la corporación pública para abrir un nuevo organismo privado afín a sus intereses. El 7 de diciembre de 2013 un alto directivo de RTVV envió una carta a diversos medios de comunicación confirmando dichas especulaciones. Asegurando además que el nuevo canal podría estar gestionado por Unidad Editorial o Tres 60, empresa vinculada a la familia de $\mathrm{M}^{\mathrm{a}}$ Dolores de Cospedal $^{80}$

Después del cierre de RTVV nuevos escándalos comenzaron a salir a la luz como los gastos millonarios que los gestores de RTVV realizaron y los nombres propios que habían estado malversando fondos en la corporación.

Con su clausura se descubrió una gestión caótica en la que se perdieron 1.200 millones de euros. La imputación de Lola Johnson ${ }^{81}$ y otros cuatro ex-directivos de la cadena (Luis Redondo, Lluís Motes, Nuria Romeral y José López Jaraba) elevó a 127 los cargos públicos del PP valenciano que han sido investigados por presunta corrupción, según Sergi Castillo.

Rescatada por Fabra como su directora de comunicación, la exconsellera, ex-jefa de informativos y ex-directora de RTVV, dimitió nada más trascender la imputación para no perjudicar, según sus palabras, la acción del gobierno valenciano. Gracias a la denuncia de Compromís debe responder por varias supuestas irregularidades en Canal 9.

Por ejemplo, la adquisición de documentales por encima del precio de mercado a una productora que también los vendió a Intereconomía $\mathrm{TV}$, un posible trato de favor a dos televisiones conservadoras (Las

\footnotetext{
${ }^{80}$ Noticia consultada el 20-12-13 en http://www.kaosenlared.net/component/k2/item/75508-un-altocargo-dertvv-revela-que-el-pp-forz $\% \mathrm{C} 3 \% \mathrm{~B} 3$-el-cierre-para-crear-un-canalaf $\%$ C $3 \%$ ADn.html

${ }^{81}$ Lola Johnson fue investigada por supuesta malversación de fondos, apropiación indebida y fraude en la quiebra de Ràdio Televisió Valenciana.
} 
Provincias TV y Mediterráneo TV, ésta última propiedad del Obispado) por el transporte de su señal o los pagos sin apenas contraprestaciones al Villarreal, un club de fútbol ${ }^{82}$.

Aunque el 23 de julio de 2014, Johnson lanzaba balones fuera responsabilizando a la Generalitat de autorizar los gastos de RTVV ${ }^{83}$. Finalmente, en 2015 se levantó la imputación de Johnson, Motes, Romeral, manteniendo en la causa al ex director general José López Jaraba y al ex director de Canal 9 Luis Redondo ${ }^{84}$.

RTVV ha servido de ejemplo para demostrar la politización de las televisiones públicas españolas. Fue un instrumento de propaganda política, cuyos gestores sólo se preocuparon por conseguir resultados electorales en detrimento del derecho de los ciudadanos valencianos a recibir un servicio público útil y veraz.

Lo más triste ha sido comprobar como los políticos, han hecho y deshecho a su antojo en RTVV. Muestra de ello fue cuando el TSJCV anuló el ERE, decidieron cerrar el ente público porque habían perdido el control total sobre el mismo.

No obstante, apoyados con la mayoría absoluta del PPCV en Les Corts, lograron aprobar las medidas que más les beneficiaban a sí mismos.

A pesar de que, en los últimos días, bajo el control de los trabajadores, se demostró que haciendo una programación de calidad y unos informativos veraces la audiencia regresaba a RTVV, fue mucho más beneficioso para los intereses de la Generalitat, cerrar el ente que cambiar a unos modelos de gestión y producción más eficientes y comprometidos con su labor de servicio público.

No obstante, la televisión no es culpable de nada, como afirmó el escritor Jaime de Armiñán, "es un espejo en el que nos miramos

${ }^{82}$ Consultado el 17-06-2014 en http://www.eldiario.es/cv/investigacionJohnson-Canal-PPvalenciano 0 263173757.html

${ }^{83}$ Noticia consultada el 23-07-2014 en http://www.lasprovincias.es/politica/201407/23/lola-johnson-antejuez20140723075804.html

${ }^{84}$ Noticia consultada el 23-01-2016 en http://www.elmundo.es/comunidadvalenciana/2015/11/06/563cc81922601dce418b46c4.html 
todos, y al mirarnos nos reflejamos" y RTVV ha sido el reflejo más fiel de una Comunidad cuyos políticos han sucumbido a la corrupción, donde se despilfarraba el dinero público en obras megalíticas que nunca se realizaban, en la que sus Cajas de Ahorros se hundían por financiar los caprichos de los políticos y se silenciaba a las víctimas del mayor accidente de metro en España, entre otras cosas. 


\section{5 \\ Una segunda oportunidad para RTVV}

T A historia de RTVV ha estado marcada por la censura y las 1 dificultades para ejercer el Periodismo libremente, hecho que la audiencia castigó con índices muy bajos. El ensalzamiento del partido en el Gobierno ${ }^{85}$ y la ausencia de los partidos de la oposición de manera sistemática, fueron demasiado evidentes. La manipulación era burda y las críticas se hacían cada vez más patentes en la sociedad valenciana.

Tras su cierre en 2013, los ciudadanos han sufrido durante más de dos años un apagón informativo, que finalmente puede revertirse en el 2016.

Con la salida de PPCV del gobierno de la Generalitat Valenciana, se han comenzado a restituir políticas que hacía años estaban siendo subyugadas de manera continuada. Entre ellos la restauración de transparencia en casos como el accidente de Metro de Valencia, en las cuentas públicas y también el restablecimiento de la Radio Televisión Valenciana.

El 17 de julio de 2015, el nuevo Gobierno autonómico aprobó la creación del Alto Consejo Consultivo de Radiodifusión, Televisión y Otros Medios de Comunicación de la Generalitat (ACC-RTV) ${ }^{86}$. A continuación, el 29 de octubre de 2015, Les Corts aprobaron la

\footnotetext{
${ }^{85}$ Partido Popular

${ }^{86}$ Noticia consultada el 15-01-2016 en http://www.levanteemv.com/comunitat-valenciana/2015/07/17/consell-crea-alto-consejoconsultivo/1291985.html
} 
tramitación de la proposición de Ley por la que la Generalitat recuperará el servicio de radio y televisión pública en valenciano.

Posteriormente, se formó una comisión de expertos compuesta por profesores de Comunicación provenientes de las universidades de la Comunidad: Universidad Jaume I, Universidad de Valencia, Universidad Politécnica de Valencia, Universidad Miguel Hernández, Universidad Cardenal Herrera CEU y Universidad de Alicante.

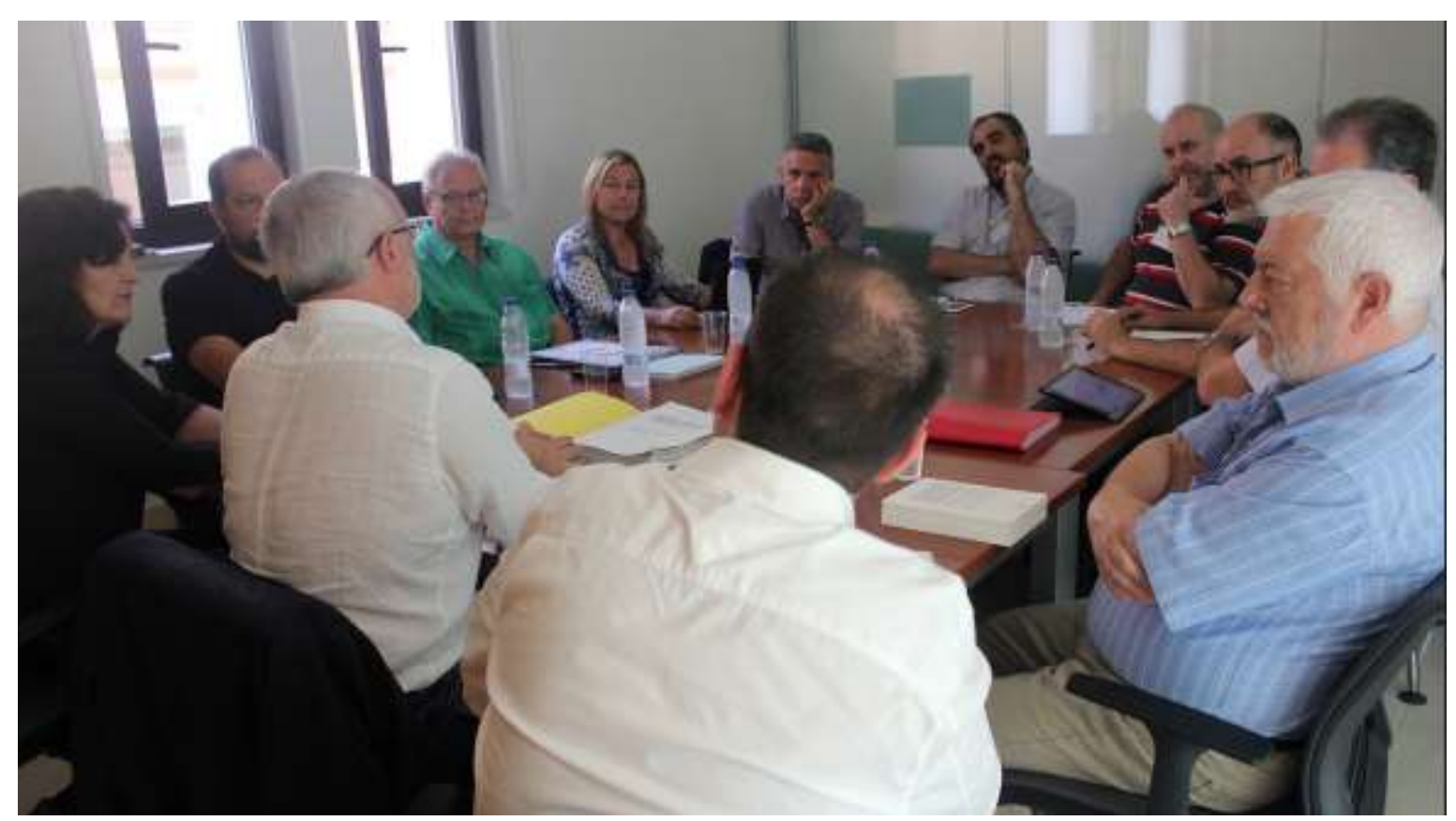

Ilustración 18. Comisión de expertos de las universidades valencianas.

En dicha comisión se elaboraron las Bases per a la renovació de léspai comunicatiu valencià $i$ la restitució del servei públic de radiotelevisió. ${ }^{87} \mathrm{Un}$ documento que establece las directrices para poner de nuevo en funcionamiento RTVV, con un nuevo nombre: Corporació Valenciana de Mitjans de Comunicació (CVMC). Aunque en esta ocasión, con la intención de que verdaderamente cumpla su labor de servicio público.

De este modo se han contemplado aspectos como su financiación, presupuestos, tipo de programación y de publicidad, evaluación de calidad... con el fin de no volver a cometer los mismos errores que en el pasado.

${ }^{87}$ Informe presentado el 20 de noviembre de 2015 
En primer lugar, los expertos hacen referencia a la depuración de responsabilidades del cierre de RTVV y de abrir un proceso que esclarezca los hechos ${ }^{88}$. Asimismo, refuerza la idea de que "La nueva radiotelevisión pública de los valencianos y las valencianas ha de servir fielmente a la promoción de la lengua y cultura valencianas, con una programación completamente en valenciano, y con el objetivo de proyectar una imagen plural, moderna y respetuosa con la realidad de la Comunidad Valenciana." (CECUV, 2015:27)

El informe señala la importancia de:

"que los contenidos informativos ha de respetar el pluralismo social y político, así como basarse en la información de proximidad. El modelo prevé la integración de los servicios de radio, televisión, contenidos bajo demanda y en movilidad, interactividad, etc. La titularidad será pública y la gestión directa, se apuesta por la cualidad y adaptación a la evolución tecnológica, una emisión abierta, gratuita y en valenciano, así como sumisión a los mecanismos de control democrático y parlamentario que aseguren la veracidad, pluralidad y participación. La puesta en marcha de los diferentes servicios que han de integrar el modelo de radiotelevisión pública requerirá una memoria justificativa y la definición de un sistema de financiamiento adecuado." (CECUV, 2015: 33)

El estudio propone un ente en el que se establezcan mecanismos de control externo como: el Consell Valencià de la Comunicació, la Comissió de Control Parlamentari de Les Corts valencianas, la Sindicatura de Comptes, el Consell Valencià de Cultura y l'Acadèmia Valenciana de la Llengua. En cuanto a los órganos de control interno deberían ser: Direcció General de la CVMC, el Consell d'Administració, el Comité de Redacció dels Serveis Informatius, el Defensor o Defensora de l'Audiència, el Consell Assessor y el Comité d'Empresa.

\footnotetext{
${ }^{88}$ Testimonios de periodistas de Radio 9 sobre la manipulación y censura ejercidos por la dirección de RTVV en casos como el accidente de metro, el caso Gürtel o las manifestaciones estudiantiles. Consultado el 11-03-2016 en https://www.youtube.com/watch?v=nz3Yd7oUijM\&feature=youtu.be\&app= desktop
} 


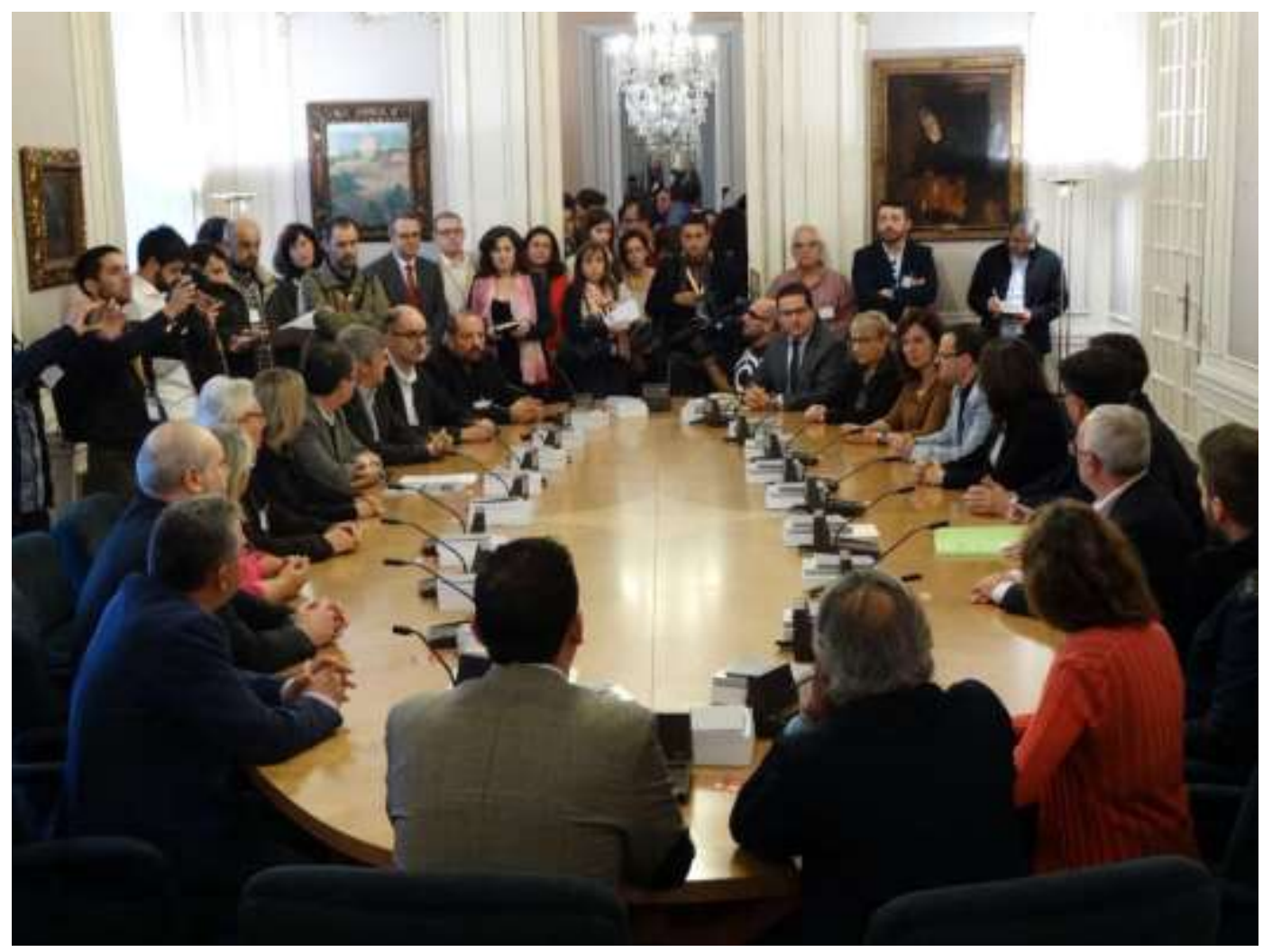

Ilustración 19. Imagen de la presentación del informe de expertos para la reapertura de RTVV

Es sustancial reseñar la importancia de la creación del Consell Valencià de Comunicació, que debe ser "autónomo e independiente respecto de los poderes legislativo y ejecutivo, que represente la pluralidad de la sociedad valenciana y que incluya a todos los sectores $\mathrm{y}$ agentes que intervienen como productores $\mathrm{y} / \mathrm{o}$ receptores de estos medios"

Igualmente, se establecen medidas para reforzar la independencia de la nueva radiotelevisión valenciana como: la elección de la Dirección General por mayorías reforzadas en Les Corts; que la directiva esté activa en periodos de seis años y sólo puedan ejercer un máximo de dos periodos; que el director/a de la CVMC no pueda formar parte del Consejo de Administración del mismo, etc. (CECUV, 2015:5153)

Sobre el modelo productivo, el informe apuesta por una radiotelevisión multicanal, con producción propia $(35 \%)$ mayoritariamente, pero también externalizada (25\%), ajena $(25 \%)$, asociada $(10 \%)$ y con cabida para nuevos formatos $(5 \%)$. 
En la visión de los expertos destacan la información (25\%), la ficción $(35 \%)$, el entretenimiento $(30 \%)$, los deportes (5\%) y la educación $(5 \%)$ como ejes temáticos principales.

Por otro lado, creen conveniente la creación de la Agència Valenciana per al Foment de l'Adiovisual (AVFA) "que actúe como una oficina valenciana de gestión de las diferentes iniciativas para la producción de contenidos audiovisuales de proximidad para la nueva corporación de radiotelevisión valenciana. La entidad se encargaría de coordinar las iniciativas de las diferentes instituciones valencianas para ordenar diferentes convocatorias y certámenes que propicien la producción audiovisual valenciana" (CECUV, 2015:70-75)

En cuanto a la financiación recoge la necesidad de que el ente sea totalmente transparente y sostenible económicamente para ello proponen un modelo mixto en el que tanto la Administración como la publicidad sean su fuente de ingresos.

- "El financiamiento de la nueva Corporació Valenciana de Mitjans de Comunicació ha de ser suficiente, sostenible y transparente para garantizar el despliegue de un servicio público de calidad y con garantías de independencia, responsabilidad y singularidad.

- Se ha de prohibir de manera clara y expresa el endeudamiento de la nueva radiotelevisión.

- Se ratifica el derecho al canon como fórmula financiera para la nueva radiotelevisión.

- El modelo mixto que combina la subvención pública otorgada por el Gobierno, los ingresos publicitarios y la explotación y comercialización de productos es el sistema de financiamiento más conveniente para la futura radiotelevisión.

- La publicidad se ha de entender como una herramienta para dinamizar económicamente tanto el sector publicitario valenciano como el tejido empresarial local, haciendo posible que las pequeñas y medianas empresas valencianas 
encuentren en la nueva radiotelevisión una ventana para promocionar sus productos y servicios.

- El presupuesto de la nueva radiotelevisión ha de basarse en un criterio de proporcionalidad de población vs. coste por habitante. Se recomienda fijar 28,76 euros por habitante, hecho que generaría un presupuesto anual de 142 millones de euros. En todo caso, nunca se habría de bajar de un coste de 22 euros por habitante que representa un presupuesto anual, mínimo, de unos 109 millones de euros.

- Las partidas del presupuesto, con un porcentaje específico del gasto total para cada una de éstas, serán: plantilla (35\%), gastos de producción propia y compra de producción ajena y de derechos de emisión (30\%), producción propia externalizada (30\%) y otros gastos (5\%)." (CECUV, 2015:8889)

Por otro lado, se regula la contratación de personal, contemplando la reincorporación de los extrabajadores de RTVV y garantizando la contratación externalizada bajo unos parámetros que beneficien a empresas del sector valenciano. Además de incluir "mecanismos de transparencia en la gestión presupuestaria de la futura CVMC: control interno y externo, ofreciendo de forma pública y abierta, a través de Internet, toda la información sobre la ejecución presupuestaria y publicar, por parte del Gobierno de la Generalitat Valenciana, el gasto anual por habitante que general la radiotelevisión." (CECUV, 2015:89)

Finalmente, se establece la creación de una comisión de expertos temporal que lleve a término el diseño empresarial de la nueva RTVV.

El 22 de diciembre de $2015^{89}$, Les Corts aprobaron la proposición de Ley que deroga el artículo que suprimió la prestación del servicio público de radio y televisión autonómico por la Generalitat, así como

\footnotetext{
${ }^{89}$ Noticia consultada el 02-03-2016 en http://www.elmundo.es/comunidadvalenciana/2015/10/29/56322077268e3eda5f8b4678.html
} 
la Ley de 2015 que fijó cinco exigencias para la puesta en marcha de una nueva RTVV.

Son cuantiosas las deudas y gastos que todavía tiene RTVV, entre ellas 1.6 millones de euros que deberán abonarse a los extrabajadores, en concepto de la paga extra de 2012.

Además, es destacable el pago del alquiler del suelo de la sede en Alicante, cuyo edificio se construyó con dinero público por 4.48 millones de euros pero que en 2002 el Gobierno del PPCV comprometió a todos los valencianos a pagar un alquiler al propietario del suelo durante 33 años, momento en el cual se le regalaría el edificio al propietario del terreno, a menos que se ampliara el contrato a 50 años. Actualmente este contrato está siendo revisado por el actual Gobierno de la Generalitat con el fin de rescindirlo ${ }^{90}$.

A pesar ello, un informe de la Comisión de Liquidación de RTVV ha estimado que el valor del ente actual triplica al de la deuda ${ }^{91}$.

Recientemente se han elegido los 5 vocales ${ }^{92}$ (representantes de cada partido) del Alto Consejo Consultivo de Radiodifusión, Televisión y Otros Medios de Comunicación. Este organismo es el encargado de estudiar la situación actual de RTVV y su puesta en marcha lo antes posible. Se prevé el 29 de noviembre de $2016^{93}$ como día de reapertura del servicio, coincidiendo así con el tercer aniversario de su apagón.

A pesar de que los últimos informes anuncian la obsolescencia de los medios técnicos ${ }^{94}$, incrementando las dificultades para la reapertura, sin duda es una puerta de esperanza que se abre en la Comunidad

\footnotetext{
${ }^{90}$ Noticia consultada el 02-03-2016 en http://valenciaplaza.com/rtvv-negociala-rescision-del-contrato-leonino-de-su-sede-en-alicante

${ }^{91}$ Noticia consultada el 02-03-2016 en http://www.elmundo.es/comunidadvalenciana/2016/03/02/56d5e474268e3e642e8b45ad.html

${ }^{92}$ Noticia consultada el 29-3-2016 en http://valenciaplaza.com/elegidos-porunanimidad-los-vocales-del-alto-consejo-consultivo-de-rtvv

${ }^{93}$ Noticia consultada el 02-03-2016 en http://www.abc.es/espana/comunidadvalenciana/abci-29-noviembre-2016-podemos-pone-fecha-reaperturatelevision-valenciana-201602241635 noticia.html

${ }^{94}$ Noticia consultada el 31-03-2016 en http:/ / www.elmundo.es/comunidadvalenciana/2016/03/03/56d7466b46163f1a0b8b45e7.html
} 
Valenciana. Una nueva coyuntura para hacer las cosas bien, para conseguir un servicio público auténtico, independiente, donde tenga cabida toda la sociedad valenciana, en definitiva, una oportunidad para no repetir los errores del pasado.

\section{Bibliografía}

Anchels Cubells, J M. (2002) Canal 9: historia de una programación (19891995). Tesis doctoral. Consultado el 16-05-2014 en: http://eprints.ucm.es/tesis/inf/ucm-t26349.pdf

Almiron, N. (2009) "Grupos privados propietarios de medios de comunicación en España: principales datos estructurales y financieros" en: Communication and Society/Comunicación y Sociedad, vol. XXII, n. 1, 2009, pp. 243-263. Consultado el 2910-2013 en:

http://www.unav.es/fcom/comunicacionysociedad/es/articulo. php?art id $=36$

Apreza Salgado, S. (2004) Veracidady pluralismo informativo en el medio televisivo: una tarea pendiente. Universidad de Salamanca.

Aubach Guiu, M. T. (1994) Comunicación y pluralismo. Unión Pontificia Salamanca.

Aznar, H. (2005) Comunicación responsable. La autorregulación de los medios. Ariel. Barcelona.

Azurmendi, A. (2007) La reforma de la televisión pública en España. Tirant lo Blanch. Valencia.

Badillo O’Farrell, P. (2003) Pluralismo, tolerancia, multiculturalismo: reflexiones para un mundo plural. Akal ediciones. Madrid.

Barambones Zubira, J. (2009) La traducción audiovisual en ETB-1: estudio descriptivo de la programación infantil y juvenil. Tesis. Vitoria-Gasteiz. Consultado el 02-11-2013 en: http://www.ehu.es/argitalpenak/images/stories/tesis/Ciencias Sociales $/ \mathrm{La} \% 20$ traduccion $\% 20$ audiovisual $\% 20$ en $\% 20$ ETB $1 . \% 20$ 
Estudio $\% 20$ descriptivo $\% 20 \mathrm{de} \% 201 \mathrm{l} \% 20$ programacion $\% 20$ infan til $\% 20 \mathrm{y} \% 20$ juvil.pdf

Berrocal, S. VV.AA. (2003) Comunicación politica en televisión y nuevos medios. Ed. Ariel. Barcelona.

Bustamante, E. (2006) Radio y televisión en España: historia de una asignatura pendiente de la democracia. Gedisa. Barcelona.

Campos-Freire, F. (2013): "El futuro de la TV europea es híbrido, convergente y cada vez menos público", en Revista Latina de Comunicación Social, 68. La Laguna (Tenerife): Universidad de La Laguna, pp. 089 a 118; Consultado el 25-09-2013 en: http://www.revistalatinacs.org/068/paper/970 Santiago/04 Ca mpos.html

Caldevilla Domínguez, D. (2013) "Efectos actuales de la 'sobreinformación' y la 'infoxicación'" a través de la experiencia de las bitácoras y del proyecto I+D avanza "radiofriends"” Revista de Comunicación de la SEECI. 2013. Año XVII (30), pp. 34-56 Consultado el 28-02-2014 en:

http://www.seeci.net/revista/index.php/seeci/article/view/7/p df 22

Casado Ruíz, A. (2011) "Debates electorales en televisión: nuevos contenidos para nuevos formatos". Consultado el 18-10-2013 en: http://www.aeic.org/tarragona2012/contents/comunicacions c d/ok/350.pdf

Casero, A. (2009) "El control político de la información periodística". RLCS, Revista Latina de Comunicación Social, 64, La Laguna (Tenerife): Universidad de La Laguna, pp. 354 a 366. Consultado el 26-07-2013 en:

http://www.revistalatinacs.org/09/art/29 82847 ULEPICC 0 $\underline{\text { 8/Andreu Casero.html }}$

Castells, M. (2009) Comunicación y poder. Alianza Editorial, Madrid.

Cebrián Herreros, M. (2004) La información en televisión. Obsesión mercantil y política. Ed. Gedisa. Barcelona. 
Chomsky, N. (1996) Como nos venden la moto. El control de los medios de comunicación; pensamiento único y nuevos amos del mundo. Icaria.

Cisneros, J. (2002) "El concepto de la comunicación: El cristal con que se mira". Ámbitos No 7-8. $2^{\circ}$ Semestre 2001 - 1er Semestre 2002, pp. 49-82. Consultado el 25-09-2013 en: http://grupo.us.es/grehcco/ambitos07-08/cisneros.pdf

Conesa, D. S. E. (2007). "El habla de los políticos: del eufemismo al insulto, pasando por el (buen o mal) talante". En Las destrezas orales en la enseñanza del español L2-LE: XVII Congreso Internacional de la Asociación del Español como lengua extranjera (ASELE): Logroño 27-30 de septiembre de 2006. pp. 997-1014. Universidad de La Rioja. Consultado el 25-09-2013 en: http://dialnet.unirioja.es/descarga/articulo/2470138.pdf

Debray, R. (1994) Vida y muerte de la imagen. Historia de la imagen en occidente. Paidós.

Estrella, M y Rincón, O. (1999). Televisión: Pantalla e identidad. Quito. Friedrich Ebert Stiftung.

Ferry, J M. Wolton, D. VV.AA. (1995) El nuevo espacio público. Gedisa. Barcelona.

Graber, D. A. VV.AA. (2007) The Politics of News: The News of Politics. CQ Press.

Hallin, D. C. y Mancini, P. (2004) Comparing media Systems: three models of media and politics. Cambridge University Press.

Jivkova Semova, D. (2011) "RTVE sin publicidad: un modelo de financiación en estado de emergencia”. Revista de Comunicación Vivat Academia. Año XIII, No116, pp. 75-91. Consultado 05-082015 en:

https://dialnet.unirioja.es/descarga/articulo/4859505.pdf

Maarek, P. J. (1997) Marketing politico y comunicación. Claves para una buena información política. Paidós Comunicación. Barcelona.

Manfredi Díaz, A y García Hernández, G. (1999) “Canal Sur 19881999” Revista andaluza de comunicación Ámbitos No 2, 
Enero-Junio, pp. 163-210 Consultado el 20-09-2013 en:

http://grupo.us.es/grehcco/ambitos02/ambitos02.pdf

Marzal, J. y Casero, A. (eds.). (2007). El desarrollo de la televisión digital en España.

Molins, J. VV.AA. (2006). Elecciones y comportamiento electoral en la España multinivel. CIS. Madrid.

Mollà, T. (2010) “Un pla estratègic per a RTVV. Revista Arxius". No. 23, pp. 59-68.

- Ídem. (2009) Quina televisió pública? Amenaces i oportunitats a l'era digital. Editorial Bromera.

Moragas Spá, M., VV.AA. (1999) Televisión de proximidad en Europa: experiencias de descentralización en la era digital. Universitat de València.

Muñoz Alonso, A., VV.AA. (1990). Opinión pública y comunicación política. Eudema Universidad Manuales. Madrid.

Lakoff, G. (2007) No pienses en un elefante. Lenguaje y debate politico. Editorial Complutense, Madrid.

López-Rico, C.M. (2012) Pluralismo informativo en los programas informativos de Canal 9 y La 1 (TVE) durante las elecciones autonómicas y generales de 2011. Tesis doctoral presentada el 20 de diciembre de 2012 en la Universidad Miguel Hernández Elche.

Ortega, F. (2011). La política mediatizada. Alianza editorial. Madrid.

Pasquali, A. (2007) Comprender la comunicación. Gedisa. Barcelona.

Pérez, M.J. VV.AA. (2013) "Sumar nueve... Y analizar el resultado en el mercado televisual español”. Revista Historia y Comunicación Social Vol. 18, pp. 515-528. Consultado el 22-01-2014 en: http://revistas.ucm.es/index.php/HICS/article/view/44346

Piedrahíta, M. (1995). "El rapto de la televisión pública. Estudios sobre el mensaje periodístico". N 2. Consultado el 12-03-2014 en: 
http://revistas.ucm.es/index.php/ESMP/article/view/ESMP95 $\underline{95110085 \mathrm{~A} / 13107}$

Quintas Froufe, E. y N. (2010): "Cara a cara electoral televisado. Análisis audiovisual de los debates entre los candidatos a la Presidencia del Gobierno Española 2008”, en Miguel Hernández Communication Journal, No 1, páginas 20 a 39. Universidad Miguel Hernández, UMH (Elche-Alicante). Consultado el 20-122013 en

http://rev.innovacionumh.es/index.php?journal $=$ mhcj\&page $=$ ar ticle\&op=view\&path $\% 5 \mathrm{~B} \% 5 \mathrm{D}=15 \&$ path $\% 5 \mathrm{~B} \% 5 \mathrm{D}=27$

Ricaute, C. (2008). “Televisión global. La caja”. El Universo. Vida y Estilo. p. 2

Rincon, O. (2006). Narrativas mediáticas, o cómo se cuenta la sociedad del entretenimiento. Barcelona. Gedisa.

Sánchez Ruiz, E.E. (1991) "La televisión pública en Estados Unidos:

Una descripción acrítica". Guadalajara: Comunicación y Sociedad, $\mathrm{N}^{\circ} 12$, mayo-agosto.

Soler Sánchez, M. (2001). Campañas electorales y democracia en España. Universitat Jaume I.

Sartori, G. (1998) Homo videns. La sociedad teledirigida. Ed. Taurus. Madrid.

Xambó, R. (2010). "Els mitjans de comunicació al país valencià". Universidad de Valencia. Revista Arxius, No 23, diciembre, pp. 316

\section{Otros documentos}

BBC. (2007) Directrices editoriales. V alores y criterios de la BBC. Asociación de Prensa de Madrid. Madrid.

- Annual report 2012. BBC Group. Inside BBC, www.bbc.co.uk

Comissió d'experts en comunicació de les universitats valencianes CECUV (2015) Bases per a la renovació de l'espai comunicatiu valencià $i$ 
la restitució del servei públic de radiotelevisió. Informe realizado para la Generalitat Valenciana.

Ley General de Comunicación 7/2010

Ley Orgánica Régimen Electoral General LOREG

Ley 8/2009 de 28 de agosto, de Financiación de la Corporación de Radio Televisión Española

Ley 3/2012, de 20 de julio, de Estatuto de Radiotelevisión

Valenciana. BOE Núm. 188 martes 7 de agosto de 2012 Sec.

I. pp. 56284. Consultado el 10-09-2012 en:

http://www.boe.es/boe/dias/2012/08/07/pdfs/BOE-A-201210558.pdf

RTVV SAU (2014). Memoria explicativa de las causas objetivas que justifican el procedimiento de despido colectivo en la sociedad radiotelevisión valenciana, S.A.U. (en liquidación) Consultado el 28-02-2016 en: http://www.rtvv.es/documentos/MEMORIA EXPLICATIVA .pdf

Real Decreto Ley 15/2012, de 20 de abril, de modificación del régimen de administración de la Corporación RTVE, previsto en la Ley 17/2006, de 5 de junio.

Resolución de 16 de julio de 2013, de la directora general del Secretariado del Consell y Relaciones con Les Corts, por la que se dispone la publicación del contrato programa entre el Consell y Radiotelevisión Valenciana S.A., para el período 2013-2015 DOCV Núm. 7070 18-07-2013 Consultado el 20-08-2013 en: http://www.docv.gva.es/datos/2013/07/18/pdf/2013 7572.pd $\underline{f}$ 


\section{Autora}

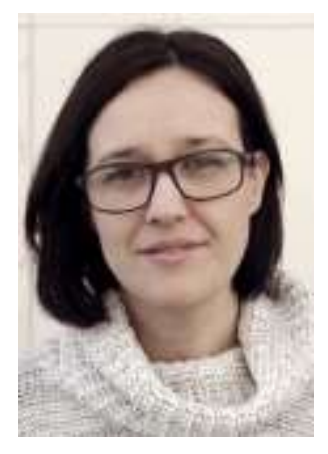

\section{Carmen $\mathbf{M}^{\mathrm{a}}$ López Rico}

Universidad Miguel Hernández (UMH) carmen.lopez05@graduado.umh.es

Doctora en Periodismo (2012) por la Universidad Miguel Hernández. Sus investigaciones se han basado fundamentalmente en el estudio de la Comunicación Política, contemplando las perspectivas de los distintos agentes que interactúan en el proceso: tanto desde punto de vista de los medios, como de los ciudadanos y partidos. En este sentido ha analizado varias campañas electorales en España, estudiando el pluralismo informativo en televisiones públicas y constatando, cuan importantes son las herramientas de control/autocontrol para garantizar unos mínimos en los medios de titularidad pública.

Es miembro del grupo de investigación I+D Mediaflows de la Universidad de Valencia, así como del Grupo de Investigación sobre Comunicación de la Comunidad Valenciana (GICOV) en la Universidad Miguel Hernández, donde también es Editora Técnica Adjunta de la revista Miguel Hernández Communication Journal. 